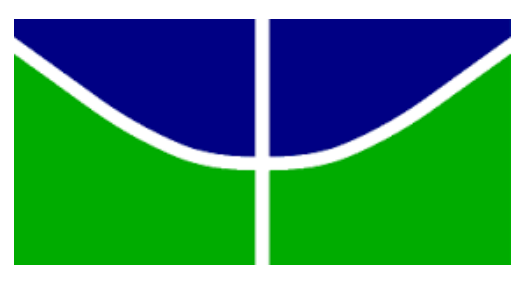

UNIVERSIDADE DE BRASÍLIA

FACULDADE DE EDUCAÇÃO

PROGRAMA DE PÓS-GRADUAÇÃO EM EDUCAÇÃO

MESTRADO PROFISSIONAL

JULIANE VARGAS

A RELAÇÃO ENTRE A OFERTA E DEMANDA DE CURSO TÉCNICO DE NÍVEL MÉDIO SUBSEQUENTE: UM ESTUDO SOBRE O CURSO DE PESCA DO INSTITUTO FEDERAL DO CEARÁ, CAMPUS ACARAÚ 
JULIANE VARGAS

\section{A RELAÇÃO ENTRE A OFERTA E DEMANDA DE CURSO TÉCNICO DE NÍVEL MÉDIO SUBSEQUENTE: UM ESTUDO SOBRE O CURSO DE PESCA DO INSTITUTO FEDERAL DO CEARÁ, CAMPUS ACARAÚ}

Dissertação apresentada ao Programa de Pós- Graduação em Educação Profissional da Faculdade de Educação da Universidade de Brasília, como parte dos requisitos para obtenção do título de Mestre em Educação na área de Políticas Públicas e Gestão da Educação Profissional e Tecnológica.

Orientador: Prof. Dr. Bernardo Kipnis

Brasília 
Ficha catalográfica elaborada automaticamente, com os dados fornecidos pelo(a) autor(a)

\section{Vargas, Juliane}

A relação entre a oferta e demanda de curso técnico de nível médio subsequente: um estudo sobre o Curso de

V297 Pesca do Instituto Federal do Ceará, campus Acaraú \ Juliane Vargas; orientador Bernardo Kipnis. - Brasília, DF, 2016 .

131 f.: il. color. $30 \mathrm{~cm}$

Dissertação (Mestrado em Educação) Universidade de Brasília, Faculdade de Educação, Brasília, DF, 2016.

1. Ensino Técnico. 2. Políticas Públicas. 3. Pesca. I. Kipnis, Bernardo, orient. II. Título. 


\section{Universidade de Brasília \\ Faculdade de Educação \\ Programa de Pós-Graduação em Educação \\ Dissertação de Mestrado}

JULIANE VARGAS

\section{A RELAÇÃO ENTRE A OFERTA E DEMANDA DE CURSO TÉCNICO DE NÍVEL MÉDIO SUBSEQUENTE: UM ESTUDO SOBRE O CURSO DE PESCA DO INSTITUTO FEDERAL DO CEARÁ, CAMPUS ACARAÚ}

Dissertação apresentada ao Programa de Pós-Graduação em Educação

Profissional da Faculdade de Educação da Universidade de Brasília, como parte dos requisitos para obtenção do título de Mestre em Educação.

Orientador: Prof. Dr. Bernardo Kipnis

Banca examinadora:

Prof. Dr. Bernardo Kipnis (Orientador)

Faculdade de Educação - FE/UnB

Prof. Dra. Maria da Conceição da Silva Freitas (Membro Interno)

Departamento de Teoria de Fundamentos - SER/UnB

Prof. Dr. André Godim do Rego (Membro Externo)

Instituto Federal de Brasília

Prof. Dr. Remi Castione (Suplente)

Faculdade de Educação - FE/UnB

Aprovado em

1




\section{DEDICATÓRIA}

Dedico este trabalho ao meu pai, Mauro Vargas, e à minha saudosa avó materna, Opracínia Korneiczuk. Com ambos, desde a infância, compartilhei o prazer de várias pescarias. Ao lado de meu pai, muitas coisas ditas e apaziguadas por meio de um diálogo silencioso. Com a minha avó, aprendi que pescar não requer apenas técnica. É preciso alegria e bom ânimo. Talvez por isso, não raras vezes, eu tenha voltado para casa sem nenhum peixe e minha avó com vários quilos, apesar de sempre ter me sentado a menos de um metro dela ... 


\section{AGRADECIMENTOS}

À minha mãe, Neusa Korneiczuk Vargas, pelo amor incondicional e pelas orações que me sustentaram nesse percurso e ao meu querido irmão, Fabiano Vargas, pelo apoio e presença sempre constante.

Ao meu companheiro de estrada e de sonhos, Carlo Arena, pelo carinho, estímulo, apoio e compreensão nos momentos de pressão e estresse. Ti voglio bene ...

Ao meu orientador Bernardo Kipnis, pela paciência e zelosa orientação. Obrigada por me ajudar a concretizar esse sonho. Foi uma honra, professor.

À Vania Maria Moraes Ferreira, minha gratidão e afeto pela presença nos momentos cruciais de minha trajetória acadêmica.

Ao Professor João Vicente, pelos valiosos esclarecimentos e principalmente por me dar direção e foco.

Ao Professor Toivi e Haulison, responsáveis pelas minhas primeiras reflexões sobre o tema.

Aos Professores Rodrigo e Soniamar pelo apoio e sugestões.

À Professora Elvira Veras, Coordenadora da CREDE 3, pelo carinho e autorização para realização desta pesquisa junto às escolas públicas de ensino médio de Acaraú.

Aos Professores Remi e Conceição, pelas sugestões que enriqueceram este trabalho.

Aos meus colegas de mestrado, pelo divertido e solidário tempo que passamos juntos.

Aos meus colegas de trabalho, Araújo, Lara, Luciano e Márcio, pela compreensão nas horas difíceis.

Ao Professor Edmar Moraes, pelos grandes feitos na área da pesca e pela defesa de uma vida mais digna aos pescadores.

Aos servidores do IFCE/Campus Acaraú, participantes da pesquisa, pelo tempo e atenção que me dispensaram.

Ao Geraldo, Thyago e Lara, pelas contribuições na construção desse trabalho.

Aos Diretores Philipe, Artur, Netinho e Francisco Luiz, por viabilizarem a pesquisa em suas escolas. Às Professoras Janaína e Terezinha (Tomaz Pompeu) e Iara (Vicente de Paulo da Costa) pela cordial recepção e apoio. angústia.

À Fátima Barboza, amiga querida e de fé, companheira nos momentos de

A todos os alunos participantes da pesquisa, em especial Monalisa (Aranaú), Natiele (Juritianha), Samuel e Suellen (Acaraú), pela ajuda na localização dos pais entrevistados.

A todos os pais de alunos por me receberem gentilmente em suas casas.

Por fim, aos pescadores e marisqueiras que eu tive o prazer de entrevistar, pessoas simples e sábias, a minha reverência e eterna gratidão pelas inspiradoras lições de vida. 


\begin{abstract}
RESUMO
O presente trabalho se propõe a estudar a relação entre a oferta e demanda do Curso técnico de nível médio subsequente em pesca do Instituto Federal do Ceará, campus Acaraú. A baixa demanda do curso tem se revelado desde a sua implantação, apesar da vocação histórica do município voltada à atividade da pesca. Nesse sentido, o objetivo central é investigar em que medida os alunos do $3^{\circ}$ ano do ensino médio das escolas públicas de Acaraú e seus Distritos, principal público alvo do curso, se interessam por cursos técnicos, em especial pelo curso de pesca. A perspectiva utilizada foi o estudo de campo. Como suporte teórico aborda-se a evolução histórica da gestão da pesca, o panorama legal da pesca e as políticas públicas destinadas a esse segmento, bem como as vicissitudes do pescador artesanal e o caráter transgeracional de sua atividade. A pesquisa de abordagem mista, quantitativa e qualitativa, utilizou como instrumentos de coleta de dados a aplicação de questionários estruturados aos alunos do $3^{\circ}$ ano do ensino médio das escolas públicas de Acaraú e Distritos e entrevistas semiestruturadas com os genitores dos alunos e servidores - docentes e técnicos - do IFCE, campus Acaraú e um gestor do MEC, envolvido com políticas públicas. Os resultados obtidos apontam o interesse maior dos concluintes do ensino médio por cursos em nível de graduação. A falta de informação sobre o curso e sua proposta, bem como a pesca ser uma atividade árdua, perigosa e de baixa remuneração são outros fatores que levam à baixa demanda do curso. A construção de arranjos produtivos locais e a aproximação do Instituto com a comunidade de pescadores por meio de ações de extensão que elevem a autoestima desta categoria e estimulem o empreendedorismo e associativismo podem contribuir para a elevação da demanda.
\end{abstract}

Palavras-chave: Pesca. Políticas Públicas. Curso Técnico Subsequente. Oferta. Demanda. 


\begin{abstract}
This aim of this study is to examine the relationship between supply and demand in the subsequent technical course in fishing of the Federal Institute of Ceará (IFCE), Acaraú campus. The course's low demand has been shown since its implementation, despite the historical vocation of the city dedicated to the fishing activity. In this sense, the main objective is to investigate the extent to which students of the 3rd year of high school in public schools of Acaraú and its districts, the main target audience of the course, are interested in technical courses, in particular the fishing course. The study was conducted as a field study. Theoretical support address the historical evolution of fisheries management, the legal landscape of fishing and public policies aimed at this segment as well as the changes of the artisanal fisherman and the transgenerational nature of its activity. The research used a mixed quantitative and qualitative approach, and used a data collection application of structured questionnaires to students of the 3rd year of high school in Public Schools of Acaraú and its Districts, semi-structured interviews were also conducted with the parents of students and servants - teachers and technicians - of the IFCE campus Acaraú and a Ministry of Education's manager involved with public policy. The results show a greater interest of high school students to graduation courses. The lack of information about the course and its proposal, as well as fishing be an arduous, dangerous and low-paid activity are other factors that lead to low demand of the course. The construction of local production arrangements and the approach of the Institute with the fishing community through outreach activities that raise self-esteem in this category and stimulate entrepreneurship and associations can contribute to the increase in demand.
\end{abstract}

Keywords: Fishing. Public policy. Subsequent Technical Course. Offer. Demand. 


\section{LISTA DE GRÁFICOS}

Gráfico 1 - Continuação dos estudos após o ensino médio.............................................46

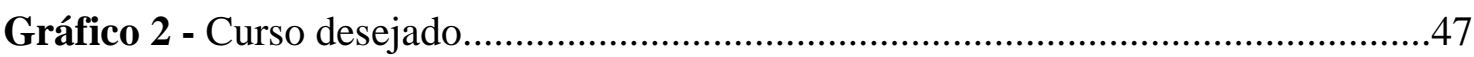

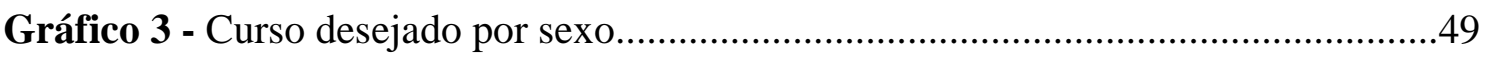

Gráfico 4 - Alternativas após a conclusão do ensino médio: bacharelado, licenciatura,

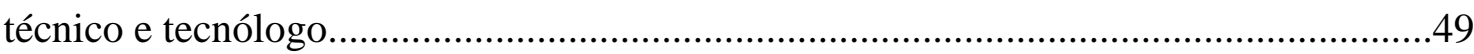

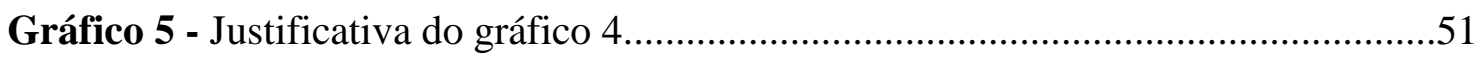

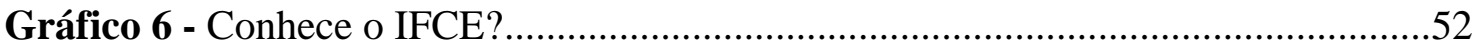

Gráfico 7 - Respostas válidas, inválidas e opção “nenhum”..........................................53

Gráfico 8 - Escolhas dos cursos por ordem de preferência............................................53

Gráfico 9 - Você conhece o Curso Técnico em Pesca do IFCE?....................................54

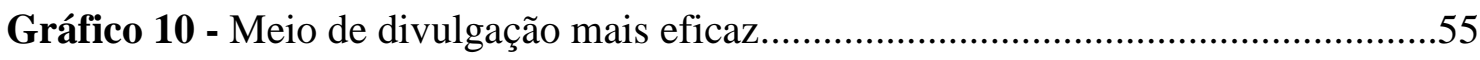

Gráfico 11 - Se os pais incentivariam o ingresso dos filhos no curso de pesca..............56

Gráfico 12: Alguém de sua família é pescador ou pescadora?....................................57 


\title{
LISTA DE GRÁFICOS
}

\author{
APL \\ Arranjo Produtivo Local. \\ CCA \\ CEFET \\ Coordenação de Controle Acadêmico. \\ CIR \\ CREDE \\ DPA \\ EaD \\ EPM \\ IBAMA \\ Centros Federais de Tecnologia. \\ Caderneta de Identificação e Registro. \\ Coordenadoria Regional de Educação. \\ Departamento de Pesca e Aquicultura. \\ Educação à Distância. \\ Ensino Profissional Marítimo. \\ Instituto Brasileiro do Meio Ambiente e dos Recursos Naturais \\ Renováveis. \\ IBGE \\ ICMBio \\ Instituto Brasileiro de Geografia e Estatística. \\ IDH \\ IF \\ IFCE \\ IFRN \\ LDB \\ MEC \\ MMA \\ MPA \\ NUPA \\ OCB \\ PDI \\ PEP \\ POP \\ Instituto Chico Mendes de Conservação da Biodiversidade. \\ Índice de Desenvolvimento Humano. \\ Instituto Federal de Educação, Ciência e Tecnologia. \\ Instituto Federal de Educação Ciência e Tecnologia do Ceará. \\ Instituto Federal de Educação Ciência e Tecnologia do Rio \\ Grande do Norte. \\ Lei de Diretrizes e Bases da Educação. \\ Ministério da Educação. \\ Ministério do Meio Ambiente. \\ Ministério da Pesca e Aquicultura. \\ Núcleo de Pesquisa Aplicada à Pesca e Aquicultura. \\ Organização das Cooperativas Brasileiras. \\ Plano de Desenvolvimento Institucional. \\ Pescador Especializado. \\ Pescador Profissional. \\ PROFROTA Programa Nacional de Financiamento da Ampliação e \\ Modernização da Frota Pesqueira Nacional. \\ PRONATEC Programa Nacional de Acesso ao Ensino Técnico e Emprego. \\ RCP \\ RGP \\ Ressuscitação Cárdio Pulmonar. \\ SEBRAE \\ Registro Geral da Pesca. \\ SETEC \\ SUDEPE \\ Serviço Brasileiro de Apoio às Micro e Pequenas Empresas. \\ Secretaria de Educação Profissional e Tecnológica. \\ Superintendência de Desenvolvimento de Pesca. \\ TCLE \\ ZEE \\ Termo de Consentimento Livre e Esclarecido. \\ Zona Econômica Exclusiva.
}




\section{SUMÁRIO}

1 INTRODUÇÃO

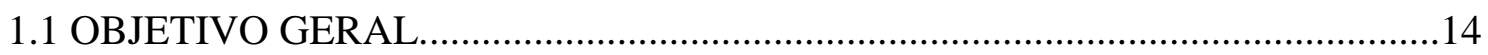

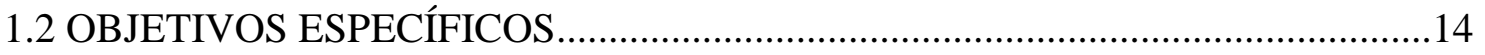

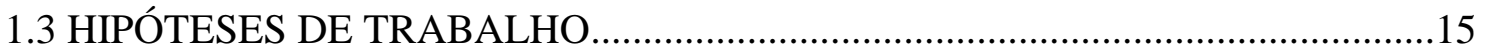

2 O CONTEXTO DA REALIDADE E O SEU PROBLEMA........................................16

2.1. O MUNICÍPIO DE ACARAÚ ………………………………………………....16

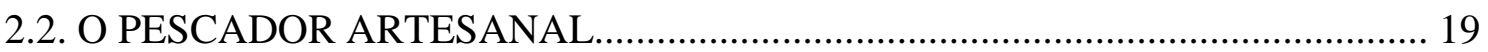

2.3. A IMPLANTAÇÃO DO CURSO TÉCNICO SUBSEQUENTE EM PESCA E O SEU PLANO DE CURSO .................................................................................23

3 A PESCA, SUAS POLÍTICAS PÚBLICAS E O PESCADOR ARTESANAL....26

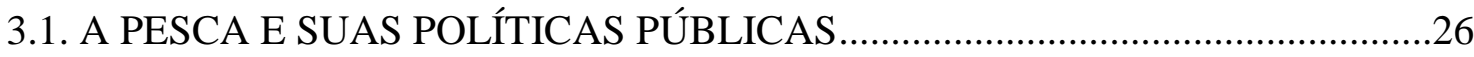

3.2. AS VICISSITUDES DO PESCADOR ARTESANAL E O CARÁTER TRANSGERACIONAL DE SUA ATIVIDADE.........................................................32

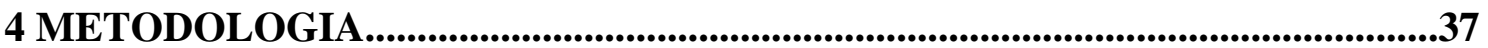

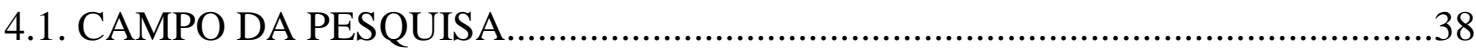

4.2. PARTICIPANTES

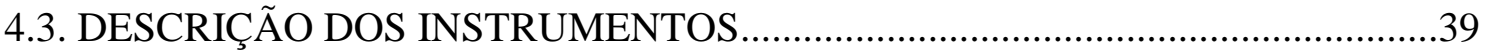

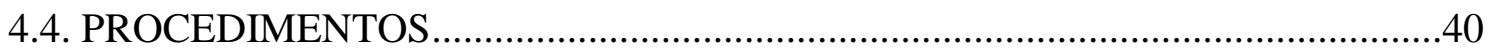

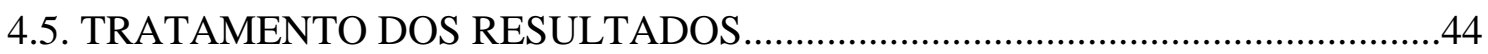

5 A VISÃO DOS ATORES..................................................................................................45

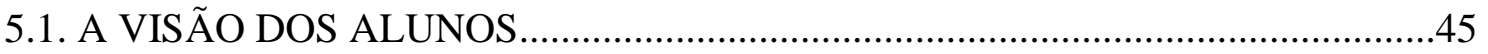

5.2. A VISÃO DO GESTOR DO MEC, GENITORES E SERVIDORES DO IFCE.....58

5.2.1. A visão do gestor do MEC.........................................................................................58

5.2.2. A visão dos genitores.................................................................................................61

5.2.3. A visão dos servidores do IFCE...............................................................................82 
APÊNDICE A - Carta solicitando autorização para realização da pesquisa junto às Escolas Estaduais de Ensino Médio à CREDE - Coordenadoria Regional de Educação.

APÊNDICE B - Termo de Consentimento Questionário Semiestruturado.

APÊNDICE C - Termo de Consentimento Entrevista. 124

APÊNDICE D - Instrumentos de Pesquisa (questionário e roteiros de entrevista). 


\section{INTRODUÇÃO}

Na última década, o Brasil apresentou elevado índice de crescimento econômico, sobretudo se comparado às economias da Europa e América do Norte. Tal fato, aliado ao controle inflacionário existente desde o governo de Fernando Henrique Cardoso (Plano Real), permitiu uma evolução da área educacional, tanto no setor público quanto no privado.

Neste contexto, foi instituída, por meio da Lei $\mathrm{n}^{\circ}$ 11.892, de 29 de dezembro de 2008 (BRASIL, 2008), a Rede Federal de Educação Profissional, Científica e Tecnológica e a criação dos Institutos Federais de Educação, Ciência e Tecnologia (IFs) (BRASIL, 2008). Estas últimas são instituições de educação superior, básica e profissional, pluricurriculares e multicampi, especializadas na oferta de educação profissional e tecnológica nas diferentes modalidades de ensino.

Parte das instituições que atualmente formam a Rede Federal de Educação Profissional, Científica e Tecnológica se originaram das dezenove escolas de aprendizes artífices instituídas pelo Decreto $n^{\circ}$ 7.566, de 23 de setembro de 1909 (CÂMARA DOS DEPUTADOS, 1909), assinado pelo então Presidente Nilo Peçanha (CÂMARA, 2015). Em 1942, após o Ensino Profissional ser considerado de nível médio, os liceus passam a se chamar Escolas Industriais e Técnicas; no início da década de 1960, tornaram-se Escolas Técnicas Federais; em seguida, Centros Federais de Tecnologia (CEFETs); e, por fim, com o advento da Lei no 11.892/2008, de Institutos Federais.

O Instituto Federal de Educação Ciência e Tecnologia do Ceará (IFCE) trilhou o mesmo caminho de transformações, a saber: Liceu Industrial do Ceará, em 1941; Escola Técnica Federal do Ceará, em 1968; Centro Federal de Educação Profissional e Tecnológica do Ceará (CEFET-CE), em 1994; e, posteriormente, Instituto Federal, em 2008 .

Atualmente o IFCE é composto por 25 campi, entre os quais a unidade de Acaraú, município com terras banhadas pelo rio Acaraú e também pelo mar. Por se tratar de uma região de grande potencial hídrico, extensa margem litorânea, clima tropical e abrigar comunidades de pescadores que desenvolvem a atividade pesqueira, o campus opera com o eixo tecnológico da área marítimo-portuária, voltada à pesca e aquicultura. 
A Instituição oferta 02 (dois) cursos de graduação (Licenciatura em Física e Ciências Biológicas) e 04 (quatro) cursos técnicos de nível médio subsequentes, destinados àqueles que concluíram o Ensino Médio (Pesca, Aquicultura, Construção Naval, Restaurante e Bar).

Dentre os 4 cursos ofertados, o curso de pesca é o que apresenta menor demanda, posicionando-se como última opção em termos de preferência pelos candidatos concorrentes às vagas da Instituição, em sua maioria concluintes do ensino médio das escolas públicas de Acaraú e Distritos ${ }^{1}$.

Tal situação tem preocupado os gestores da entidade, razão pela qual mereceu ser investigada. Assim, esta pesquisa parte das seguintes indagações: em que medida os jovens em idade escolar no Ensino Médio se interessam pela educação profissional e, principalmente, pelo Curso Técnico de Nível Médio em Pesca do IFCE, campus Acaraú? Considerando o potencial e a vocação laboral da região voltados à atividade pesqueira, o que justificaria a baixa demanda?

Para responder a essas perguntas propôs-se a aplicação de um questionário estruturado, dirigido aos alunos do $3^{\circ}$ ano do ensino médio das escolas públicas de Acaraú e seus distritos e a realização de entrevistas com servidores do campus, um representante do MEC envolvido com políticas públicas e os genitores ou representantes legais dos mencionados alunos.

A estrutura do trabalho inicia-se com a introdução, objetivos da pesquisa e hipóteses de trabalho e divide-se em Seções, a seguir especificados.

A Seção 2 - O contexto da realidade e seu problema, subdivide-se da seguinte forma: O Município de Acaraú, onde traz informações históricas e socioeconômicas do município; O pescador Artesanal, onde aborda o perfil e o modo de vida desta categoria; A Implantação do Curso Técnico Subsequente em Pesca e o seu Plano de Curso, onde estão descritos o problema de pesquisa e as informações básicas sobre o curso.

A Seção 3 - A pesca, suas políticas públicas e o pescador artesanal foi dividida em dois subtítulos: A pesca e suas políticas públicas, onde se aborda o conceito de política pública, breve evolução histórica da gestão da pesca, o panorama legal da pesca, bem como as políticas públicas dirigidas a esse segmento; As vicissitudes do pescador

\footnotetext{
${ }^{1} \mathrm{O}$ detalhamento sobre a baixa demanda, com dados oficiais da Instituição, consta da Seção 2, item 2.3 deste trabalho.
} 
artesanal e o caráter transgeracional de sua atividade, onde se disserta sobre a influência do ambiente familiar na formação de seus integrantes e sobre os reveses da atividade pesqueira artesanal, este último baseado nos estudos de Antonio Carlos Diegues (1983) e Simone Carneiro Maldonado (1986 e 1993), representantes da socioantropologia marítima.

Na Seção 4 - Metodologia, aborda-se a metodologia que norteou a pesquisa, com a apresentação de seus participantes e a descrição dos instrumentos utilizados para sua realização.

Na Seção 5 - Visão dos atores, são apresentados os dados da pesquisa e respectivas análises decorrentes da aplicação do questionário e entrevistas organizadas em categorias.

A Seção 6 - Produto Técnico, consiste numa metodologia própria de divulgação do curso técnico em pesca, cujo objetivo precípuo é informar os alunos do ensino médio sobre a proposta do curso e o tipo de profissional que este se propõe a formar, melhorando, assim, a divulgação do mesmo.

O trabalho se encerra com a Conclusão, onde se traz um resumo dos resultados da pesquisa, as considerações da pesquisadora sobre esses resultados e sugestões que eventualmente possam contribuir para elevação da demanda do curso de pesca.

\subsection{OBJETIVO GERAL}

Analisar a relação entre oferta e demanda do Curso Técnico de Nível Médio em Pesca do IFCE, campus Acaraú.

\subsection{OBJETIVOS ESPECÍFICOS}

- Identificar se os concluintes do $3^{\circ}$ ano do Ensino Médio das Escolas Públicas de Acaraú se interessam por cursos técnicos, em especial, pelo Curso Técnico de Nível Médio Subsequente em Pesca do IFCE, campus Acaraú

- Discriminar os cursos de preferência dos alunos $3^{\circ}$ ano do Ensino Médio das Escolas Públicas de Acaraú após a conclusão do ensino médio 
- Analisar a percepção dos genitores ou responsáveis legais dos concluintes do $3^{\circ}$ ano do Ensino Médio das Escolas Públicas de Acaraú sobre a profissão de pescador e suas principais dificuldades

- Levantar informações sobre a implantação e oferta do Curso Técnico de Nível Médio Subsequente em Pesca

- Identificar o cenário atual da oferta do Curso Técnico de Nível Médio Subsequente em Pesca

- Desenvolver uma metodologia própria de divulgação do Curso Técnico de Nível Médio em Pesca ofertado pelo IFCE, para captação de demanda junto às escolas de Ensino Médio de Acaraú

\subsection{HIPÓTESES DE TRABALHO}

As hipóteses de trabalho relacionadas à baixa demanda do curso de pesca são:

a) O não reconhecimento social e a marginalização do pescador;

b) A pesca é uma atividade árdua, perigosa e de baixa remuneração;

c) Os pais ou responsáveis legais dos concluintes do $3^{\circ}$ ano do Ensino Médio não estimulam a escolha pelo Curso Técnico de Nível Médio em Pesca por não vislumbrarem perspectivas de futuro na área da pesca;

d) O interesse maior dos concluintes do ensino médio pelos cursos em nível de graduação;

e) A falta de informação sobre o curso e sua proposta, haja vista existir um entendimento equivocado de que este se destina a formar pescadores. 


\section{O CONTEXTO DA REALIDADE E SEU PROBLEMA}

\subsection{O MUNICÍPIO DE ACARAÚ}

Acaraú é um município localizado no litoral oeste do estado do Ceará, a 255,1 km de Fortaleza e aproximadamente $60 \mathrm{~km}$ da Praia de Jericoacoara ${ }^{2}$. Possui 842,566 Km2 e uma população estimada em 61.210 habitantes (2015). O rendimento médio mensal familiar per capita em 2010 foi de $\mathrm{R} \$ 215,00$ e a taxa de analfabetismo funcional (15 anos ou mais) é de 28, 83\% (IBGE, 2015).

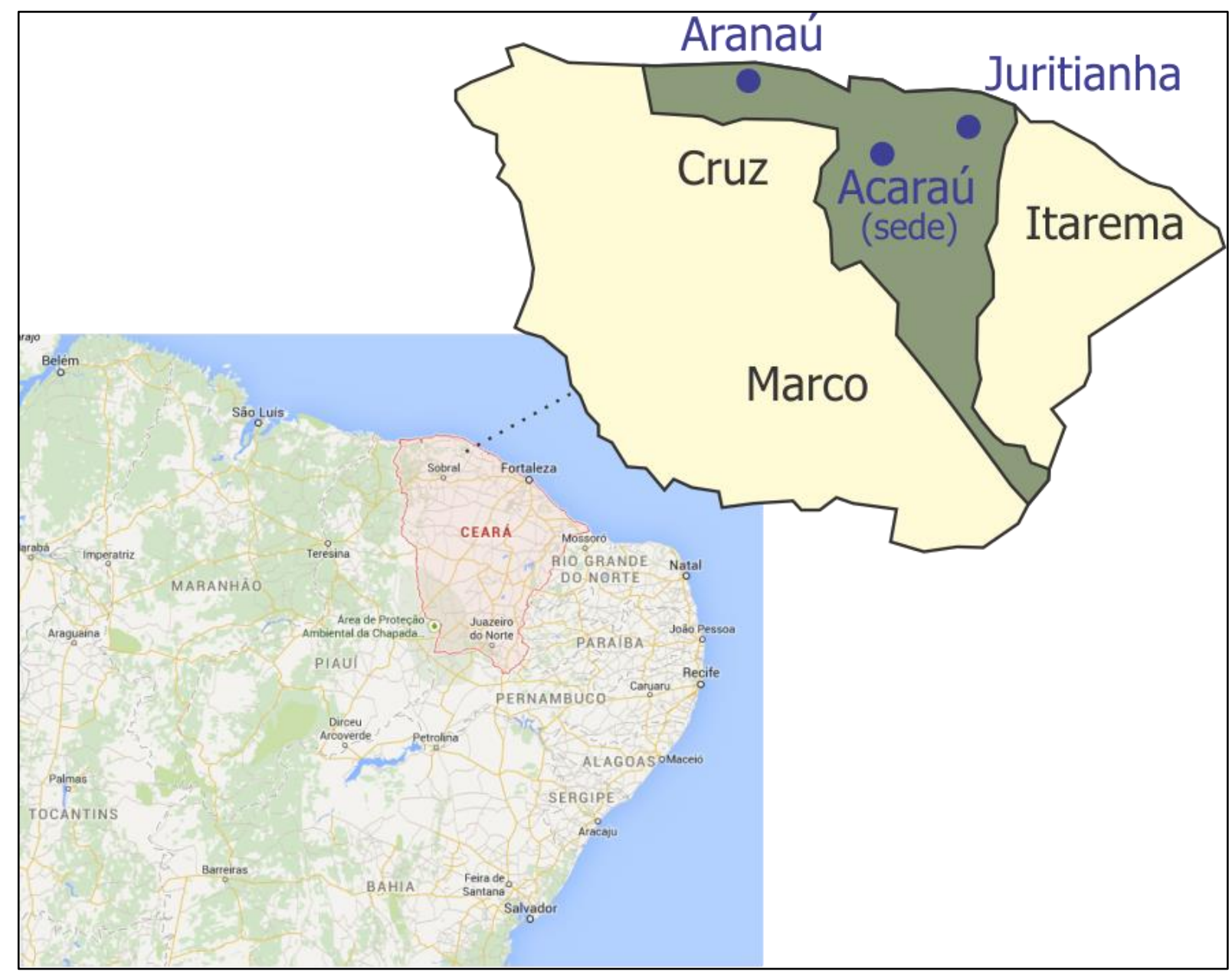

FIGURA 1: mapa da região nordeste do Brasil, destacando o Estado do Ceará, o Município de Acaraú e os Distritos de Aranaú e Juritianha. Fonte adaptada de: Soniamar Zschornack Rodrigues Saraiva. Dissertação (mestrado) - Universidade Federal do Ceará, Instituto de Ciências do Mar, Programa de PósGraduação em Ciências Marinhas Tropicais, Fortaleza, 2015.

\footnotetext{
${ }^{2}$ Praia de Jericoacoara: situada no Município de Jijoca de Jericoacoara, foi eleita em 1994 pelo jornal Washington Post como uma das praias mais bonitas do planeta.
} 
O Índice De Desenvolvimento Municipal (IDM) no ano de 2010 foi de 29,16, e o de desenvolvimento humano (IDH) para o mesmo ano figurou em 0,617. O percentual da população extremamente pobre (com renda per capita de até $\mathrm{R} \$ 70,00$ mensais), foi de $31,91 \%$, tendo a zona rural apresentado percentual mais elevado que a zona urbana: 38,57\% (INSTITUTO DE PESQUISA E ESTRATÉGIA ECONÔMICA DO CEARÁ, 2012).

Pompeu Sobrinho (apud PAIVA, 2010) destaca que os índios Tremembé foram os primeiros pescadores da região do Ceará e dominavam toda a costa do estado à época do Descobrimento. Ressaltou como principais características desse povo a coragem, a inteligência e a compleição física bastante forte.

As pescarias atuais guardam, até hoje, influências indígenas, não apenas nos métodos de pesca como também nos nomes atribuídos aos peixes (PAIVA, 2010).

Gonçalves (2011, p. 555), relaciona as principais espécies comerciais marinhas presentes no litoral cearense: Bonito, Cação, Caicó, Camorim, Camurupim, Cangulo, Carapitanga, Cavala, Cioba, Dentão, Dourado, Garoupa, Guaiúba, Garajuba, Guaracimbora, Mero, Palombeta, Pargo, Pescada, Sardinha, Serra, Sirigado, Vermelho e Xaréu.

A histórica vocação do Município de Acaraú voltada à pesca é tratada por Nicodemos Araújo:

Segundo o Barão de Studart, os primeiros povoadores teriam sido "pescadores vindos do sul". Parece-nos, todavia, que tudo leva a corroborar nossa hipótese, que o Rio das Graças foi visitado por europeus logo nos primórdios do século XVI. Vicente Yanez Pinzon, e logo após Diogo de Lepe, ambos espanhóis, aqui estiveram e fizeram na enseada de Jericoacoara - isso antes da chegada de Pedro Alvares Cabral a Porto Seguro. Já no primeiro mapa do continente americano, de Juan de La Cosa, figura a "Barra do Rio Grande", como é chamado no famoso "Mapa da Capitanias", em 1574. Os mapas de Cantino, em 1502 e de Canério, em 1505, registraram igualmente a presença da barra. Em 1516, no mapa de Pedro Reinel, aparece a foz do Acaraú, designada como "Barra dos Parcéis". E na carta de Gaspar Viegas, datada de 1534, surge a costa do Acaraú chamada pelo nome de "Terra da Pescaria", o mesmo nome que lhe dá Diogo Homem, em 1558. Atestando a extrema abundância das águas do Acaraú, o inglês Rotz, em seu mapa de 1542, denomina a área de "Barra de Pees" (Barra dos Peixes). De acordo com o Dr. Tomaz Pompeu Sobrinho, a atual cognominação de Acaraú sob a forma variante Acaracú, só aparece no começo do décimo sétimo século. Os documentos aí estão, portanto, mostrando, por um lado, a antiguidade do povoamento, e por outro lado, a fartura do pescado que sempre caracterizou o Acaraú, a ponto de fazer Antonio Bezerra dizer em suas "Notas de Viagem", de 1884, que "não há na província lugar mais farto nem de mais recursos que o Acaraú". (ARAÚJO, 1991, p. 7) 
Segundo Araújo (1971), não é possível precisar o ano que a indústria da pesca se instalou em Acaraú, entretanto há registro de que a Câmara Municipal recebeu, no ano de 1891, impostos de 103 currais $^{3}$. Além de expedir licenças para cada curral, a municipalidade também cobrava um emolumento denominado Taxa de Registro. Nessa época o local dos currais era demarcado pela Câmara Municipal para posterior ciência à Capitania dos Portos em Fortaleza, responsável por autorizar o levantamento das armadilhas.

O autor registra, ainda, que Acaraú iniciou a pesca da lagosta em novembro de 1961, nas praias de Cacimbas, Ilha dos Coqueiros, Volta do Rio e Almofala. As indústrias pesqueiras da cidade e algumas empresas especializadas vindas de Fortaleza, somaram, na época, 300 embarcações, desde lanchas motorizadas até canoas à remo. Em 1964 o município estimou a produção de lagosta em 150 mil quilos.

O Município de Acaraú, desmembrado do Município de Sobral, foi criado em 31 de julho de 1849 por meio da Lei nº 480, sancionada pelo Dr. Fausto Augusto de Aguiar, Presidente da Província do Ceará à época.

Atualmente a região de Acaraú possui quatro indústrias de pescado: Cajucoco, Monteiro Pescados, Allmare Alimentos e Pesqueira Loiola. As duas primeiras situam-se em Itarema, municípios vizinhos, e as demais estão instaladas em Acaraú.

A unidade de beneficiamento da Cajucoco (2015) tem capacidade para beneficiar 35 toneladas de camarão por dia. Além de abastecer o mercado interno, exporta para os Estados Unidos e Europa. Não possui marca própria. Recebeu, em março de 2010, o Certificado de Excelência do Programa "Garantia de Origem" do grupo Carrefour, na categoria de " abate e processamento de Camarão". Hoje a indústria opera com os seguintes produtos: lagosta, camarão, polvo e peixe.

A Monteiro Pescados (2015), pioneira na região, tem a sua atividade voltada para exportação e comercialização interna dos produtos da pesca, em especial a lagosta.

Instalada na sede de Acaraú, a indústria de beneficiamento Allmare Alimentos (2015) possui porto equipado e uma frota de 17 barcos pesqueiros. Atua no mercado nacional e internacional (Estados Unidos e Europa). Não possui marca própria.

\footnotetext{
${ }^{3}$ Curral: armadilha fixa em forma de cerca armada em bancos de areia próximos à praia ou no mar, e que possui uma abertura por onde os peixes penetram durante a maré cheia, ficando aprisionados com a descida da maré, quando então os pescadores procedem a despesca.
} 
Beneficia lagosta, peixe e camarão e tem como principais clientes o Grupo Pão de Açúcar, Sam’s Club e Assaí Atacadista.

A Pesqueira Loiola, cuja indústria situa-se em Acaraú, também não tem marca própria, entretanto presta serviços de beneficiamento a empresas que comercializam pescado. Tem como principais produtos a lagosta, o camarão e em menor volume o peixe.

Os principais ícones da economia de Acaraú são o coco, a castanha, a lagosta, o camarão e o peixe (GOVERNO MUNICIPAL DE ACARAÚ, 2015).

\subsection{PESCADOR ARTESANAL}

Consoante demonstra o Boletim do Registro Geral da Atividade Pesqueira de 2012 - RGP, existem registrados no Sistema do RGP, até 31/12/2012, 1.041.967 (um milhão quarenta e um mil e novecentos e sessenta e sete) pescadores profissionais, distribuídos em todas as 27 unidades da federação. A região nordeste concentra o maior número, representando $47,02 \%$ do total. No Ceará foram registrados 29.970 pescadores e, desse total, 952 se encontram em Acaraú (inscritos ativos).

O Registro Geral da Atividade Pesqueira (RGP) é um instrumento que contribui para a gestão e o desenvolvimento sustentável da atividade pesqueira e permite que o interessado exerça as atividades de pesca e aquicultura em toda a sua cadeia produtiva. Além de legalizar os usuários por meio de credenciamento de pessoas físicas e jurídicas, também credencia embarcações nacionais e estrangeiras. Mostra-se, portanto, um instrumento indispensável à gestão da atividade pesqueira, sobretudo por servir de apoio à concessão de licenças, permissões e autorizações para o exercício da pesca e captura de espécies.

Consoante o artigo $4^{\text {o }}$ da Lei $\mathrm{n}^{\circ} 11.959 / 2009$ ("Lei da Pesca"), “a atividade pesqueira compreende todos os processos de pesca, explotação e exploração, cultivo, conservação, processamento, transporte, comercialização e pesquisa dos recursos pesqueiros".

Desta forma, o RGP contém informações de todos os envolvidos que atuam diretamente na atividade pesqueira, compreendendo as seguintes categorias: o aprendiz de pesca, o pescador profissional (artesanal e industrial), o armador de pesca, a embarcação de pesca, a indústria pesqueira, pescador amador ou esportivo, organizador 
de competição de pesca amadora ou esportiva, aquicultor e comerciante de organismos aquáticos vivos.

Quase a totalidade dos pescadores profissionais inscritos no RGP exerce a atividade artesanalmente $(99,16 \%$ do total) e apenas $0,84 \%$ a exercem na forma industrial. Quanto à forma de atuação, o RGP indica que 75,39\% dos pescadores profissionais pescam de forma desembarcada, enquanto $24,61 \%$ pescam com auxílio de alguma embarcação. A região Nordeste possui o maior percentual de pescadores desembarcados, $35,97 \%$, seguida da região norte.

Em síntese, os dados extraídos do RGP demonstram que a pesca exercida no território brasileiro é eminentemente artesanal, na forma desembarcada, em especial na região nordeste.

Maldonado (1986), sob uma perspectiva humanista e antropológica, analisou os pescadores e os fenômenos que ocorrem em sociedades marítimas. A autora distingue os pescadores artesanais dos industriais.

Os pescadores artesanais, também chamados de "autônomos", praticam uma pesca caracterizada pela simplicidade da tecnologia e pelo baixo custo de produção, tem na pesca sua maior fonte de renda e não possuem vínculo empregatício entre as tripulações e os mestres dos botes. A produção destina-se ao consumo doméstico e à comercialização, sendo esta última dependente de intermediários em razão de não possuírem condições para conservação e transporte mais distante do pescado.

Em contraposição à estrutura da pesca artesanal estão os pescadores industriais, que trabalham em empresas pesqueiras e integram relações de trabalho exclusivamente patronais. Estes são assalariados e participam apenas da captura do pescado ${ }^{4}$. São destituídos de qualquer autonomia sobre decisões relacionadas à constituição das equipes de trabalho, rotas de pesca ou duração da jornada desta. A remuneração pelo trabalho desempenhado pode se dar tanto sob a forma de salário mensal como pequena participação na produção.

Discorrendo sobre a imprevisibilidade da produção, devido à natureza cíclica e móvel do pescado, Maldonado (1986) assevera que o contato com um elemento natural arriscado e imprevisível faria dos pescadores homens inseguros, desconfiados, pouco

\footnotetext{
${ }^{4} \mathrm{Na}$ pesca industrial três atividades básicas são desenvolvidas separadamente, por grupos distintos: captura, industrialização e comercialização do pescado.
} 
cooperativos, conservadores e individualistas, "tendendo ao segredo e à ocultação das rotas e dos bancos de peixe". (MALDONADO, 1986, p. 30)

Embora tais aspectos psicológicos, segundo a autora, passem atualmente por um releitura dos cientistas sociais, esses traços de personalidade são uma forma de se conhecer um pouco a identidade e a o modo de vida dos pescadores e, eventualmente, as razões que expliquem o conservadorismo dessa população esquiva à mudança e resistente a elementos externos à sua tradição.

Para Diegues (1993) os pescadores artesanais se identificam como sendo um grupo detentor de uma profissão, cujo domínio de um conjunto de conhecimentos e técnicas permite-lhes subsistir e se reproduzir enquanto pescadores. O que caracteriza o pescador artesanal não é apenas o viver da pesca, mas a apropriação real dos meios de produção, o controle da arte da pesca.

Mesmo trabalhando em grupo a técnica é essencialmente individual. (...) O
pescador artesanal é obrigado a dominar o manejo de diferentes instrumentos
de captura utilizado para diferentes espécies de pescado, num meio ambiente
de contínua mudança. A menor falha no assentamento da rede, no
lançamento dos cabos, pode destruir o equipamento ou danificar
irremediavelmente o motor. Isso pode significar a perda de um capital
considerável, adquirido depois de anos de trabalho intenso (DIEGUES, 1993,
p. 198).

Dominar a arte da pesca, prossegue o autor, exige do pescador qualidades físicas e intelectuais obtidas pelo aprendizado na experiência, o que lhe possibilita, também, apropriar-se dos segredos da profissão.

O segredo marca as relações relativas à informações e os mestres demonstram ser muito ciosos de sua responsabilidade para com os verdadeiros mapas que têm na memória e extremamente articulados com a natureza, ao ponto de levar o bote aos melhores lugares (MALDONADO, 1993, p. 40).

O conhecer do pescador é traduzido pela sabedoria, adquirida pela experiência de anos. Esse conhecer compreende saber como navegar, o movimento das marés, os tipos de fundo propícios à vida de determinadas espécies, noções empíricas sobre os hábitos de diversos peixes, saber relacionar os fenômenos naturais e tomar decisões seguras referentes à captura. Essa sabedoria é diferente do saber-fazer, pois não diz respeito à capacidade de manusear um apetrecho de pesca, mas sim onde e quando utilizá-lo. E isso se aprende pescando e ouvindo os mais velhos (DIEGUES, 1993). 
Esse saber tradicional transferido aos pescadores mais novos garante a sobrevivência e a reprodução da categoria:

“(...) a tomada de decisão de lançar uma rede, por exemplo, está sujeita à avaliação de uma série de fatores naturais que vão desde a posição da lua e sua influência nas marés até os hábitos migratórios do pescado na procura de seu alimento. O conhecimento dessas variáveis naturais, normalmente acumulada de maneira empírica pelos pescadores, passado de geração em geração, constitui o núcleo mais importante da expertise que caracteriza, por exemplo, o bom pescador. É verdade que a forma de adquirir e armazenar esses conhecimentos complexos tem se diversificado enormemente nas últimas décadas. O pescador lagunar de Cananéia (Brasil), por exemplo, para localizar certos tipos de peixe, como a pescada, costuma usar a canoa como caixa de ressonância para ouvir o ronco da pescada. O bom mestre de traina, pela ardentia ou brilho de um cardume de sardinha em noite escura, pode avaliar sua profundidade e volume com boa precisão. O jangadeiro do nordeste guarda seu ponto de pesca, no mar alto, por um complexo sistema de triangulação de marcas situadas na costa (pontos de morro, etc) (DIEGUES, 1993, p. 97-98).

Percebe-se que a relação complexa do pescador com a natureza revela uma categoria profissional única, distinta das demais profissões.

Sobre a organização do trabalho no mar dos pescadores artesanais, Maldonado (1986) ressalta a importância da família como unidade de produção e consumo.

A divisão do trabalho se dá da seguinte forma: os homens pescam e as mulheres se dedicam às tarefas domésticas (tarefas consideradas de terra) ou atividades no mar raso, sendo a pesca no mar alto tarefa eminentemente masculina ${ }^{5}$. Isso se dá não apenas pelo perigo que o mar alto (ou mar de fora) oferece, mas principalmente em função dos mitos que permeiam a cultura desses povos. A título de exemplo, alguns grupos de trabalho proíbem as mulheres de adentrarem nas embarcações quando se encontram no período menstrual ou no puerpério; outros, em hipótese alguma, deixam a mulher entrar nos botes ou sequer tocar qualquer instrumento ou apetrecho de pesca - redes, anzóis, espinhéis - sob o argumento de que atraem mau agouro, infortúnios e prejuízos.

No entanto, isso não significa que as mulheres não pesquem. Especialmente no Norte e Nordeste do Brasil, elas se dedicam à pequena pesca - ou pesca de mar de raso de espécies como o marisco e o caranguejo. A atividade é tradicional e o aprendizado e técnicas de coleta dos moluscos e crustáceos são passados de mãe para filha.

\footnotetext{
${ }^{5}$ No mar de dentro, também chamado de mar de terra, mulheres e crianças contribuem com a renda familiar dedicando-se ao artesanato ou confecção dos instrumentos de pesca (Maldonado, 1986, p. 20)
} 
Nota-se que a organização do trabalho do povo marítimo retrata não apenas uma postura diante do mundo, mas também delineia um identidade cultural muito particular.

\subsection{A IMPLANTAÇÃO DO CURSO TÉCNICO DE NÍVEL MÉDIO SUBSEQUENTE EM PESCA E O SEU PLANO DE CURSO}

O campus Acaraú do Instituto Federal de Educação Ciência e Tecnologia do Ceará (IFCE) foi oficialmente inaugurado em 2009, em Brasília, pelo então Presidente da República, Luiz Inácio Lula da Silva. A solenidade fez parte da inauguração simultânea de 30 unidades dos Institutos Federais de Educação, Ciência e Tecnologia (IFs). O referido campus deu início às suas atividades em uma sede provisória, pois a edificação em área de quase $6.000 \mathrm{~m}^{2}$ não fora concluída à época. O Curso Técnico de Nível Médio em Pesca, subsequente, foi um dos 03 (três) cursos inicialmente ofertados com o compromisso de levar formação profissional à população local e circunvizinha (SUSANE, 2015).

Consoante o Plano de Desenvolvimento Institucional (PDI) do IFCE, a definição dos cursos "se deu mediante a análise da vocação econômica de cada região e das suas idiossincrasias socioculturais, levando-se igualmente em conta a opinião da comunidade, a quem todo o trabalho do IFCE se destina" (INSTITUTO FEDERAL DE EDUCAÇÃO, CIÊNCIA E TECNOLOGIA, 2009, p. 65).

Segundo dados fornecidos pela Coordenação de Controle Acadêmico - CCA - do referido campus, o Curso Técnico de Nível Médio Subsequente em Pesca tem apresentado pouca demanda. Dos 04 (quatro) cursos técnicos subsequentes da entidade, o Técnico em Pesca posiciona-se como última opção em termos de preferência.

Parte dos ingressantes dos cursos ofertados pelo IF deriva das escolas públicas do Município de Acaraú - alunos concluintes do $3^{\circ}$ ano do Ensino Médio. A outra parte, em menor número, é proveniente da população que já concluiu esta etapa educacional. Desde a oferta do curso, no segundo semestre de 2010, a procura é baixa, com elevado grau de evasão escolar.

Neste sentido, é possível exemplificar tomando-se por base o primeiro semestre de 2011. No relatório expedido pela Coordenação de Controle Acadêmico (CCA), em 11 de fevereiro de 2015, a proporção candidato/vaga em cada curso técnico foi a que se segue: Pesca (0,98\%); Aquicultura (2,83\%); Construção Naval (1,90\%); e, Restaurante 
e Bar $(1,30 \%)$. Observa-se que o curso de pesca ficou em último lugar dentre os quatro ofertados.

Ademais, no período compreendido entre o primeiro semestre de 2013 e o ano de 2014, verificou-se a necessidade de realizar processos seletivos complementares, uma vez que o número de inscritos foi menor do que número de vagas ofertadas (primeiro semestre de 2013: 35 vagas para 18 inscritos; primeiro semestre de 2014: 35 vagas para 32 inscritos).

Tal situação, considerando o potencial e a vocação histórica da região voltados à Pesca,tem preocupado os gestores da entidade, razão pela qual se faz necessário investigar em que medida os jovens em idade escolar no Ensino Médio se interessam pela educação profissional e, principalmente, pelo Curso Técnico de Nível Médio em Pesca do IFCE, campus Acaraú.

O Plano do Curso Técnico de Nível Médio Subsequente em Pesca salienta que a pesca nacional é uma das poucas atividades que absorve mão-de-obra de pouca ou nenhuma qualificação, tanto na área urbana quanto rural, sendo, em alguns casos, "a única oportunidade de emprego para certos grupos de indivíduos, principalmente para a população excluída".

Tais considerações, aliadas às características da região de abrangência do curso (a bacia hidrográfica do Rio Acaraú; o imenso potencial hídrico; a extensa margem litorânea; o clima tropical com média acima de $25^{\circ}$; as comunidades de pescadores existentes no município de Acaraú; e, a pesca como atividade econômica histórica da região - em especial, a pesca de lagosta e a tradicional pesca do camurupim), evidenciam que a capacitação desta população se mostra indispensável ao desenvolvimento da atividade pesqueira da região (costa oeste do litoral cearense). Neste sentido, o IFCE entendeu relevante a implantação do curso técnico de nível médio em pesca, investindo na qualificação e requalificação de mão de obra na área da pesca, valorizando a vocação regional e elevando a qualidade dos serviços nessa área de atividade econômica.

O curso tem como objetivo geral formar profissionais de nível médio técnico, na modalidade presencial, em consonância com a demanda do mercado, com competência técnica, humanística e ética, capazes de desempenhar atividades profissionais, nas áreas de extração e manejo adequado de recursos pesqueiros, para seu aproveitamento integral 
na cadeia produtiva, com segurança, qualidade e sustentabilidade econômica, ambiental e social.

Além disso, dentre os objetivos específicos, destaca-se o preparo de profissionais para desempenhar funções na área de pesca, atuando em instituições públicas e privadas, empresas de pesca na área de beneficiamento de pescado e pesca embarcada, e também de forma autônoma, empregando técnicas adequadas para um desenvolvimento sustentável da atividade pesqueira.

Entre as competências gerais do Técnico em Pesca, destacam-se: identificar as características dos materiais utilizados na construção de apetrechos de pesca e especificar suas propriedades; realizar operações de captura de pescado, utilizando equipamento adequado; identificar as modalidades de navegação, suas características e conhecer princípios de funcionamento de motores em embarcações; realizar operações de embarque e desembarque de pescado; conhecer normas de sobrevivência para embarcações e realizar procedimentos de primeiros socorros de acordo com o tipo de acidente; conhecer os principais equipamentos eletrônicos e de comunicação marítima utilizados na pesca e seus princípios de funcionamento; operar equipamentos de captura com base em cada modalidade de pesca; conhecer e interpretar a legislação ambiental aplicada à pesca, além de outras inerentes à área; conhecer e aplicar técnicas de beneficiamento de pescado; conhecer e aplicar técnicas de embalagem, armazenamento e transporte de pescado; executar atividades de extensão e gestão na área de recursos pesqueiros; elaborar projetos para o setor pesqueiro, com base no levantamento de dados e recursos disponíveis; dominar conhecimentos básicos de informática.

O curso se dá no regime seriado semestral, com duração de 04 (quatro) períodos letivos. Até 2014.2 o primeiro período era compreendido por disciplinas de educação básica e área geral da pesca, e os 03 (três) restantes referentes às disciplinas de formação técnica, totalizando a carga horária de 1.520 horas. Atualmente, com a aprovação da nova matriz, válida a partir de 2015.1, o curso passa a ser de 1.120 horas, com 200 horas de estágio curricular opcional. 


\title{
3 A PESCA, SUAS POLÍTICAS PÚBLICAS E O PESCADOR ARTESANAL
}

\subsection{A PESCA E SUAS POLÍTICAS PÚBLICAS}

O século XX, notadamente a partir da década de 1960, foi marcado pela crescente importância da área de "Políticas Públicas". Entre vários aspectos que lhe conferiram maior atenção, o primeiro deles e, quiçá, o mais relevante, foi a adoção de políticas restritivas de gasto que alicerçaram processos de reforma do Estado em vários países ocidentais e democráticos (SOUZA, 2006).

Segundo Souza, para a compreensão do termo "Políticas Públicas", seus desdobramentos e trajetória, faz-se necessário buscar a sua origem:

\begin{abstract}
A política pública enquanto área de conhecimento e disciplina acadêmica nasce nos EUA, rompendo ou pulando as etapas seguidas pela tradição europeia de estudos e pesquisas nessa área, que se concentravam, então, mais na análise sobre o Estado e suas instituições do que na produção dos governos. Assim, na Europa, a área de política pública vai surgir como um desdobramento dos trabalhos baseados em teorias explicativas sobre o papel do Estado e de uma das mais importantes instituições do Estado - o governo , produtor, por excelência, de políticas públicas. Nos EUA, ao contrário, a área surge no mundo acadêmico sem estabelecer relações com as bases teóricas sobre o papel do Estado, passando direto para a ênfase nos estudos sobre a ação dos governos. (SOUZA, 2006, p. 21)
\end{abstract}

Toda estratégia governamental tem um pano de fundo (decisões, escolhas, caminhos). Para que se entendam as "políticas públicas" - em especial, as de cunho social -, faz-se importante compreender a relação destas com o Estado, onde, em síntese, caracteriza o conjunto de instituições permanentes que viabilizam a ação do Governo. Este, por sua vez, é o conjunto de programas e projetos que parte da sociedade apresenta para a sociedade como um todo, consubstanciando um norteador político de um governo que toma para si as funções de Estado por um determinado período. Assim, a Política Pública é o campo do conhecimento que busca "colocar o governo em ação" e, quando necessário, propor mudanças no curso desse processo (HOFLING, 2001).

Para Hofling (2001, p. 38), é importante refletir sobre a relação entre Estado, Governo e Políticas Públicas, pois os padrões de comportamento de certos atores podem interferir, por exemplo, no processo de definição e implementação de Políticas Públicas: “o processo de definição de políticas públicas para uma sociedade reflete os conflitos de 
interesses, os arranjos feitos nas esferas de poder que perpassam as instituições do Estado e da sociedade como um todo".

Frey complementa o argumento ao afirmar que:

[...] se quisermos saber mais detalhes sobre a gênese e o percurso de certos programas políticos, os fatores favoráveis e os entraves bloqueadores, então a pesquisa comparativa não pode deixar de se concentrar de forma mais intensa na investigação da vida interna dos processos político-administrativos. Com esse direcionamento processual, tornam-se mais importantes os arranjos institucionais, as atitudes e objetivos dos atores políticos, os instrumentos de ação e as estratégias políticas. (FREY, 2000, p. 220-221)

A pesca no Brasil, embora uma atividade milenar, é questão recente na área educacional. Os últimos anos apontam aumento da demanda nacional e mundial pela proteína derivada do pescado, o que torna o Brasil um potencial produtor em razão de sua extensa faixa litorânea $(8.000 \mathrm{~km})$ e $12 \%$ de toda a água doce do planeta $(8,2$ bilhões de $\mathrm{m}^{3}$ ) (MINISTÉRIO DA PESCA E AQUICULTURA, 2014).

O artigo 20 da Constituição Federal (1988) determina que o mar territorial e os recursos naturais da plataforma continental e da Zona Econômica Exclusiva (ZEE) ${ }^{6}$ são bens da União e estão sob a tutela do Estado. Mais adiante, o artigo 24 dispõe que cabe à União legislar sobre a pesca, a defesa dos recursos naturais e a proteção do meio ambiente.

Para Cotrim (2008), a evolução histórica da gestão da pesca é marcada por várias fases:

\begin{abstract}
Na década de 20, o Ministério da Marinha foi o órgão do Estado responsável pela organização da pesca no Brasil, porém, essa situação foi se modificando com o passar do tempo. Em 1934, a pesca saiu do Ministério da Marinha e passou para a Divisão de Caça e Pesca, dentro do Ministério da Agricultura. Em 1942, devido à segunda guerra mundial, a pesca saiu do Ministério da Agricultura e retornou ao Ministério da Marinha. Em 1967, no Governo Militar do Brasil, a pesca retornou ao Ministério da Agricultura, agora dentro da SUDEPE (...). Em 1989, foi extinta a SUDEPE e criado o IBAMA ligado ao Ministério do Meio Ambiente, para onde migrou a pesca. Em 2002 foi criada a SEAP, Secretaria Especial da Aquicultura e Pesca. (COTRIM, 2008, P. 19).
\end{abstract}

Mais recentemente, a gestão dos recursos pesqueiros ocorria de forma compartilhada entre o Ministério da Pesca e Aquicultura - MPA e o Ministério do Meio

\footnotetext{
${ }^{6}$ A ZEE separa as águas nacionais das internacionais e é delimitada por uma linha de 200 milhas marítimas da costa.
} 
Ambiente - MMA, figurando aquele como coordenador, nos termos do Decreto $\mathrm{n}^{\circ}$ $6.981 / 2009$, que regulamenta o artigo $27, \S 6^{\circ}$, inciso I, da Lei $n^{0} 10.683 / 2003$, que dispõe sobre a organização da Presidência da República e dos Ministérios.

Em decorrência da atual reforma ministerial empreendida pela Presidente Dilma Rousseff, o Ministério da Pesca e Aquicultura foi extinto em 05 de outubro de 2015, por força da Medida Provisória $n^{\circ} 606$ de 2015 que alterou a Lei $n^{\circ} 10.683 / 2003$, tendo havido a transferência de suas competências ao Ministério da Agricultura, Pecuária e Abastecimento.

Segundo o art. $2^{\circ}$, inc. III da Lei $\mathrm{n}^{\mathrm{o}} 11.959$, de 29 de junho de 2009, entende-se por pesca "toda operação, ação ou ato tendente a extrair, colher, apanhar, apreender ou capturar recursos pesqueiros" (BRASIL, 2009).

A lei supracitada, que dispõe sobre a Política Nacional de Desenvolvimento Sustentável da Aquicultura e da Pesca e regula a atividade pesqueira, comumente chamada de "Lei da Pesca", entrou em vigor concomitantemente à criação do extinto Ministério da Pesca e Aquicultura, que em sua origem fora uma Secretaria Especial ligada à Presidência da República.

Segundo Melo (2012), a atividade pesqueira compõe-se de dois métodos de produção. Os realizados em ambientes naturais, como no oceano e em águas interiores, são denominados de pesca extrativa ou de capturas. Já os que se desenvolvem em ambientes naturais cedidos para a exploração privada e os ambientes privados explorados pelo homem (cultivo) são chamados de aquicultura.

Ao discorrer sobre a propriedade dos recursos pesqueiros, afirma o autor:

\footnotetext{
Os recursos pesqueiros que, exclusivamente, vivem em águas de domínio privado, ou nessas se encontram quando coletados ou capturados, constitui propriedade daqueles que têm o domínio desses ambientes. Na hipótese de viverem tão somente em águas de domínio público, constituem recursos públicos, cuja exploração está sujeita às disposições do país que possui o domínio legal daquelas águas (MELO, 2012, p. 10).
}

Filardi, Rebouças e Vieira (2006), remetendo à Berkes (2005), asseveram que os recursos pesqueiros existentes em águas de domínio público são considerados recursos naturais renováveis de uso comum, ou seja, são bens livres passíveis de subtração por qualquer usuário, não havendo, assim, propriedade sobre os mesmos. 
O artigo $8^{\circ}$ da Lei $n^{\circ} 11.959 / 2009$ classifica a pesca em comercial e não comercial. A primeira, divide-se em pesca artesanal e industrial; a segunda, em científica - para fins de pesquisa, amadora - lazer e desporto, e a de subsistência, com fins de consumo doméstico ou escambo sem fins lucrativos.

Segundo dados apresentados pelo extinto Ministério da Pesca e Aquicultura, estima-se que um em cada duzentos brasileiros são pescadores artesanais. Tal atividade é exercida por produtores autônomos, em regime de economia familiar ou individual, e se destina à obtenção de alimentos para as famílias dos pescadores ou fins comerciais em pequena escala. A arte e os instrumentos de pesca são desenvolvidos pelos próprios pescadores, amparados ou não por pequenas embarcações, como, por exemplo, jangadas e canoas, razão pela qual é considerada uma atividade simples, sendo responsável por aproximadamente $45 \%$ de toda a produção anual de pescado desembarcada.

Consoante dispõe o artigo $9^{\circ}$, parágrafo 14, incisos I e II, do Decreto $\mathrm{n}^{\circ} 3.048$, de 1999 (Regulamento da Previdência Social), considera-se pescador artesanal aquele que, individualmente ou em regime de economia familiar, faz da pesca sua profissão habitual ou meio principal de vida, desde que não utilize embarcação ou, se utilizar, deverá ser de pequeno porte, nos termos da Lei $n^{\circ}$ 11.959/99. Esta Lei, comumente chamada "Lei da Pesca", considera embarcação de pequeno porte aquela que não exceda 20 toneladas, conforme dispõe o inciso I, $\S 1^{\circ}$, de seu artigo 10.

Entre as várias iniciativas governamentais voltadas ao pescador artesanal, visando a melhoria da qualidade de vida e inclusão social, destacam-se os seguintes programas: Pescando Letras, destinado à alfabetização de pescadores e aquicultores; o Programa Nacional de Acesso ao Ensino Técnico e Emprego (PRONATEC) - Pesca e Aquicultura; Projeto de Apoio a Pequenos Empreendimentos na Pesca Artesanal; Parceria Cozinha Brasil e os Telecentros.

Em relação à pesca industrial, esta compreende a utilização de embarcações de médio e grande porte, o uso de tecnologia sofisticada e depende de infraestrutura portuária para o desembarque do pescado, tendo em vista sua atividade se dar em larga escala. Em geral, os pescadores da pesca industrial possuem vínculo de trabalho com o responsável pela embarcação. Este segmento é exclusivamente comercial, de grande importância social e econômica, pois fornece matéria prima para as grandes indústrias de centros de distribuição de alimentos. 
O estado de Santa Catarina figura como o maior produtor de pescado e crustáceos do país, especial relevo para as cidades de Itajaí e Navegantes, grande polo industrial pesqueiro que se destaca pelo complexo sistema de capturas, recepção e processamento de pescado (SEBRAESC, 2010).

Vários são os portos para desembarque do pescado industrial dispostos ao longo da costa brasileira. Entretanto, têm-se como principais aqueles localizados em Belém (Pará), Fortaleza (Ceará), Rio de Janeiro (Rio de Janeiro), Santos (São Paulo), Itajaí (Santa Catarina) e Paranaguá (Paraná).

Quanto às políticas públicas voltadas ao referido segmento, desde o advento da Lei $\mathrm{n}^{\circ} 11.959 / 2009$, estas são destinadas, sobretudo, à modernização da pesca, ao fortalecimento da indústria e do comércio pesqueiros e ao desenvolvimento sustentável, destacando-se o Programa Nacional de Financiamento da Ampliação e Modernização da Frota Pesqueira Nacional (PROFROTA) e o Plano Safra - linhas de crédito com juros reduzidos.

Araújo (2011) afirma que a Lei $n^{\circ} 11.959 / 2009$ representou um avanço para o setor da pesca e da aquicultura, não apenas por fixar um marco regulatório, mas também por ampliar o acesso ao crédito, reconhecer como atividade pesqueira artesanal a confecção e reparo de petrechos, pequenas embarcações e processamento de pescado.

Azevedo e Pierri (2013), contudo, não compartilham o mesmo entendimento ao discorrerem sobre a política pesqueira atual no Brasil, onde fazem um retrospecto das políticas públicas. Afirmam que anteriormente ao Governo "Lula" a política pesqueira teve três momentos institucionais, com características distintas: o primeiro período, entre 1964 e 1989, foi marcado pelo "desenvolvimentismo modernizante e ambientalmente irresponsável”; o segundo, de 1989 a 1998, em oposição ao anterior, foi caracterizado por uma política essencialmente conservacionista e o terceiro, entre 1998 a 2003, foi permeado por uma disputa institucional "onde a tentativa de retomar o desenvolvimento setorial resultou travada pelas disposições ambientais”.

No primeiro período, as autoras destacam a SUDEPE, Superintendência do Desenvolvimento da Pesca, órgão competente pelas políticas do setor na época, como a responsável pela política desenvolvimentista, voltada especialmente à pesca industrial. Sob o enfoque econômico, tal política, segundo as autoras, provocou "o maior 
crescimento histórico contínuo da pesca extrativa”, contudo, sob o viés ambiental, gerou uma crise nos recursos pesqueiros em razão da sobrepesca ${ }^{7}$

Já no segundo período, salientam que as prerrogativas da SUDEPE foram atribuídas ao IBAMA - Instituto Brasileiro do Meio Ambiente e dos Recursos Naturais Renováveis, cuja atuação foi marcada pelo combate à pesca predatória e a adoção de instrumentos de gestão pesqueira destinados à preservação das espécies.

Em 1998, início do terceiro período, foi criado do o DPA (Departamento de Pesca e Aquicultura) junto ao Ministério da Agricultura, com o intuito de retirar a tutela ambiental do setor e recuperar a política desenvolvimentista, o que ocasionou significativos conflitos institucionais entre o referido Ministério e o IBAMA em razão da divisão de competências na gestão e ordenamento dos recursos pesqueiros.

Concluem as autoras que, ao longo desses três períodos, a pesca artesanal esteve à margem das preocupações governamentais, vez que as políticas ora se concentravam no desenvolvimento industrial do setor, ora na conservação e proteção dos recursos, fato que prejudicou sobremaneira os pescadores artesanais, os quais, em razão da crise pesqueira, foram condenados ao empobrecimento e à concorrência desleal com a pesca industrial e a aquicultura empresarial.

Acerca das políticas públicas implementadas a partir de 2009, as autoras intitulam-nas de "neodesenvolvimentistas", caracterizadas pela forte atuação governamental em investimentos em infraestrutura, oferta de crédito público e políticas de distribuição de renda viabilizada por benefícios sociais que acabaram por gerar conformismo nos setores populares.

No conjunto, a atuação governamental nos últimos anos, por trás de um discurso de suposta sensibilidade social e responsabilidade ambiental, e apesar da diminuição imediata da pobreza, tem contribuído para aumentar a vulnerabilidade e a situação de injustiça ambiental sofrida pelas comunidades pesqueiras artesanais (PIERRI, 2013, p. 10).

\footnotetext{
${ }^{7}$ Sobrepesca: exercício descuidado e predatório da pesca, que causa ameaça às espécies marítimas ou extinção das mesmas. Fonte: MALDONADO, S. C. Pescadores do mar. São Paulo: Ática, 1986. (Séries Princípios)
} 


\subsection{AS VICISSITUDES DO PESCADOR ARTESANAL E O CARÁTER}

\section{TRANSGERACIONAL DE SUA ATIVIDADE}

O ambiente familiar influencia na educação e formação de seus integrantes

(GARCIA, 2007). A cultura e os valores transmitidos das gerações mais velhas para as mais jovens não são imutáveis, uma vez que as gerações futuras, apesar da transmissão cultural, apresentam características próprias que as distinguem da geração anterior e quiçá da seguinte (BENINCÁ; GOMES, 1998, p. 179).

Garcia salienta que a alteração de alguns conteúdos culturais se deve aos condicionantes histórico-sociais presentes na vida das gerações procedentes:

Outro favor que caracteriza a transgeracionalidade nas famílias, e que vai além da mera repetição de padrões culturais, é a tentativa, em muitos casos, de rejeição do modelo familiar de origem e a busca de novos padrões ou do modelo oposto pelas gerações mais jovens (FALCKE \& WAGNER, 2005). Mesmo nesses casos ocorre a transmissão cultural, porém estas gerações mais jovens repensam os conteúdos culturais transmitidos e tentam não reproduzir os aspectos considerados insignificantes ou desfavoráveis ao bem-estar das gerações procedentes. (GARCIA, 2007, p. 19)

Transportando o contexto exposto anteriormente para uma família típica de pescadores, é de se supor que a vida árdua do homem do mar contribua para que este faça uma reflexão de sua própria história e projete no filho as expectativas e oportunidades que ele não teve. Neste sentido, Bornholdt e Wagner (apud GARCIA, 2007) destacam:

\footnotetext{
A integração da criança na família envolve o ensino de habilidades sociais e a transmissão de normas culturais. Este é um processo que, gradualmente, leva os progenitores a olharem para si e a partir de suas vivências anteriores, buscarem modelos (ou antimodelos) em como exercer a parentalidade. Esse olhar pode representar a espera de que o filho tenha oportunidades, no mínimo iguais, ou, em algumas ocasiões, exatamente opostas às suas vivências em épocas anteriores. Nesse sentido, esse é um momento que a evolução da vida favorece um encontro com o passado. (apud GARCIA, 2007)
}

A atividade pesqueira artesanal, pela sua presença na construção do conhecimento coletivo e no compartilhamento cotidiano de sua prática entre os familiares, reforça o seu caráter transgeracional. A perpetuação e a sustentabilidade da referida atividade estão ligadas à educação familiar, porém o que se assiste, segundo os relatos extraídos por Garcia (2007), é um generalizado receio quanto à continuidade da atividade pesqueira pelas gerações procedentes. Tais famílias não desejam que seus 
filhos vivenciem as situações de risco inerentes à pesca, entre as quais, os perigos do mar e as dificuldades socioeconômicas:

Eu não quero levar pra não ficar dizendo que ta motivando eles (filhos) para eles irem para o mar, daí deixa meio de lado assim, pra ver se eles vão deixando pra ver" (Roberto/ segunda geração/ família da zona urbana). "Eu digo por causa de ter uma qualidade de vida melhor, melhor que a minha. De estudar e ser alguém" (Giovane/ segunda geração/ família da zona rural). Nota-se com esta afirmação uma desvalorização da pesca como profissão e a valorização do estudo enquanto ferramenta para ascensão social, o que não é o caso da pesca. "Eles (os pais) querem que estude o que tem que estudar, te forma, que a pesca não é futuro, ele sempre falou" (Tomás/ terceira geração/ família da zona rural) (GARCIA, 2007, p. 55).

Os filhos, por sua vez, tendem a rejeitar o modelo familiar de origem, buscando novos caminhos. Como se observa na obra de Bovy, este comportamento não é recente:

Já hoje vemos, muitas vezes, os filhos de simples pescadores deixar a pesca, sobretudo quando podem frequentar instituições escolares; visam a um standing superior ao de seus pais (...) (BOVY, 1972, p.122)

Não bastasse ser a pesca uma atividade árdua e perigosa, ela também não proporciona boas condições de vida aos pescadores em razão da baixa remuneração que oferece. Isso se deve, em grande parte, aos atravessadores ou intermediários.

Diegues, em sua obra intitulada "Pescadores, Camponeses e Trabalhadores no Mar", assinala:

Para os pescadores artesanais a cidade é o mercado por excelência, onde dia a dia eles se defrontam com os atravessadores no momento de vender o peixe. É ali também que vão procurar o combustível, o gelo, o óleo. É ali que eles habitam também, geralmente em casas pobres, nos arrabaldes da cidade, ou entulhados na área do porto. Desapareceu a roça, a plantação e surgiu o mar, para onde diariamente saem para buscar o peixe, imediatamente transformado em valor de troca. (DIEGUES, 1983, p. 221)

Por ser o pescado um produto perecível, a sua produção exige investimentos na aquisição de gelo, câmaras de conservação ou até mesmo para outras formas de conservação, como a salga ou a secagem. E por não dispor o pescador de recursos suficientes à manutenção desses investimentos, submete-se à uma relação desvantajosa e dependente com o intermediário/financiador.

Tal dependência pode se dar quando os compradores impõem o preço de venda do produto, ao qual o pescador se submete; quando o pescador, por ausência de condições de ele próprio escoar a produção, se sente obrigado a vender o pescado ao 
intermediário e, por fim, quando o armador de pesca fornece ao pescador os insumos de produção em troca da garantia de compra do pescado capturado (ARAÚJO, 2009).

Essa relação de dependência havida entre o pescador artesanal e os intermediários ou industriais leva à reprodução de duas polarizações sociais: de um lado, o produtor independente - que aufere de seu trabalho baixa remuneração; de outro lado o comerciante financiador - que toma para si a maior parte do lucro (DIEGUES, 1983).

Sobre essa perniciosa relação, o citado autor, ilustrando caso de expropriação dos pescadores de seus meios de produção, relata uma situação ocorrida no estado do Ceará:

No Ceará, por exemplo, firmas de comercialização de lagosta chegaram em algumas praias emprestando os manzuás (covos para a captura da lagosta) aos pescadores, que, em contrapartida, lhes vendiam a produção. Em breve, começaram a financiar a reposição das jangadas. Pouco depois, a firma era a proprietária da maioria dos meios de produção. Quando a predação levou à diminuição da produtividade, a firma levou embora os manzuás, deixando os pescadores na miséria (DIEGUES, 1983, p. 240).

Acerca da autonomia dos pescadores, Maldonado (1986) destaca que:

\begin{abstract}
Uma das características da pesca artesanal é o poder decisório dos pescadores sobre aquilo que produzem. O processo de comercialização do pescado - seja por sua perecibilidade, seja por sua demora em se chegar com esse produto à terra - geralmente se dá através de intermediários ou atravessadores, que em toda a parte tendem a se caracterizar como gananciosos e até certo ponto indesejáveis entre os pescadores, com quem mantém relações tensas e conflituosas (MALDONADO, 1986, p. 9).
\end{abstract}

A despeito de afirmar que as relações entre intermediários e pescadores sejam tensas e conflituosas, a autora ressalta que "em muitos casos têm-se registrado relações até certo ponto amistosas entre eles, que facilitam as transações e mascaram o conflito e a desconfiança" (MALDONADO, 1986, p. 52). O fato é que, mesmo nas relações amistosas, o pescador se vê numa posição de submissão, pois depende do intermediário para fazer empréstimos e financiamento de materiais, reduzindo, assim, a margem de lucro de sua atividade.

Outros fatores, além dos relatados, também podem comprometer o modo de vida dos pescadores, desencorajando as gerações futuras a desenvolverem a atividade de pesca. 
Lopes et al. (2011), ao analisar os conceitos de território e identidade socioterritorial no âmbito da pesca artesanal no Brasil, disserta sobre os impactos resultantes de fatores econômicos, ambientais e políticos que passaram a comprometer o modo de vida dos pescadores e a fixação de sua identidade. Aquela autora atenta que apesar da urbanização das regiões litorâneas e do crescimento do turismo, a cultura pesqueira vinha se mantendo. O referido fenômeno, todavia, não ocorria nas localidades onde se instalavam grandes empreendimentos. $\mathrm{O}$ ritmo acelerado das mudanças, ainda segundo Lopes, seria o responsável por inviabilizar a "vida mais tradicional", tanto no que tange à preservação dos costumes quanto ao acesso aos recursos pesqueiros:

Muitos são forçados, por força da especulação imobiliária, a deixar a orla das praias, local primário de moradia. Outros não conseguem manter-se na pesca. Transformam-se em favelados e perdem as suas referências, adoecem, tornam-se alcoólatras, desestruturam toda a rede familiar (LOPES et al, 2011, p. 192).

Callou (2010), em seu artigo Povos do Mar: herança sociocultural $e$ perspectivas no Brasil, onde aborda as políticas públicas que ele denomina de indiferentes às reivindicações dos pescadores, aponta outras dificuldades vivenciadas por aqueles trabalhadores - estas, de natureza sanitária, quais sejam: alimentação deficiente, parcos hábitos de higiene, problemas de pele e cegueira decorrentes da constante exposição ao sol.

Diegues (1983) tece considerações sobre a moradia dos pescadores na cidade. O perigo de furto, roubo ou extravio dos equipamentos de pesca os obrigam a se concentrarem em localidades próximas ao porto de desembarque. Por se tratar de uma população pobre, sem renda fixa e vivendo de atividade aleatória, é comum despertarem atitudes de desprezo por serem considerados "gente de segunda categoria".

As considerações de Muniz (2005) em sua obra O Ouro do Mar, confirmam as afirmações de Diegues quanto à desvalorização dos pescadores, que são vistos como "preguiçosos e vagabundos".

Por ser a pesca artesanal uma atividade baseada na simplicidade, o caráter de pequena produção não possibilita ao pescador uma acumulação constante, vez que depende, basicamente, dos ciclos naturais. A sua reprodução como produtor independente está ligada, necessariamente, à abundância de pescado nas áreas costeiras que pode alcançar com a sua embarcação. Entretanto, estando o pescador cada vez mais 
dependente do mercado, isso pode levá-lo a explorar os recursos pesqueiros além de sua capacidade de reprodução natural, ocasionando, assim, uma predação desordenada de tais recursos. Isso poderá gerar o seu fim como produtor independente e sua proletarização em algum barco de pesca industrial ou, quiçá, sua marginalização como subempregado nas cidades (DIEGUES, 1983).

Lopes et al. (2011, p. 192), complementando Diegues (1983), pontua que a escassez dos recursos naturais e o baixo nível de escolaridade e qualificação profissional aumentam as possibilidades de conflitos entre os pescadores, geram sentimentos de descrença e impotência, o que contribui para a desagregação entre seus pares: "É comum ouvirmos os pescadores afirmarem: - 'Não quero que meu filho seja pescador', hoje pesca-ador!"

Observa-se que as vicissitudes enfrentadas pelos pescadores, especialmente as relacionadas aos aspectos socioeconômicos contribuem para o não reconhecimento social e a marginalização desta categoria. 


\section{METODOLOGIA}

O delineamento metodológico escolhido para esta pesquisa foi de uma abordagem mista: quantitativa e qualitativa.

A abordagem quantitativa se deu em razão da utilização de recursos e técnicas estatísticas e os resultados decorrentes da coleta de dados foram apresentados por meio de gráficos.

Oliveira destaca:
A utilização de métodos e técnicas em pesquisa está associada aos objetivos, hipóteses e aos fundamentos teóricos do objeto de estudo. Esse procedimento exige uma escolha criteriosa e sistemática para se fazer a descrição, explicação e análise de fatos e fenômenos. Esse procedimento se faz através da abordagem qualitativa e da abordagem quantitativa, ou ainda com a aplicação simultânea desses dois tipos de abordagem para interpretação e análise do objeto de estudo. (OLIVEIRA, 2013, p. 58)

Já a abordagem qualitativa, indicada ao tipo de estudo sobre opiniões, valores ou crenças de determinado grupo, mostrou-se hábil para compreender a realidade de forma mais completa. Neste sentido, Dal-Farra e Lopes enumeram as vantagens da abordagem qualitativa:

\footnotetext{
A capacidade de gerar informações mais detalhadas das experiências humanas, incluindo suas crenças, emoções e comportamentos, considerando que as narrativas obtidas são examinadas dentro do contexto original em que ocorrem. Além disso, [...] proporcionam análises profundas das experiências humanas no âmbito pessoal, familiar e modelos variados. (DAL-FARRA; LOPES, 2013, p.71)
}

De fato, a utilização das duas abordagens não é apenas factível, mas também recomendável, como conclui Oliveira (2013, p. 58): “[...] esses dois tipos de abordagem não são excludentes, pois, na opção por uma pesquisa qualitativa, pode-se recorrer a dados quantitativos para melhor análise do tema em estudo e vice-versa”.

Os problemas abordados pelos pesquisadores das ciências sociais costumam ser de difícil compreensão e o uso de apenas uma das abordagens, quantitativa ou qualitativa, é inadequado para enfrentar a complexidade peculiar desse ramo do conhecimento. Assim, pode se mostrar mais eficaz, no sentido de maior compreensão dos problemas investigados, a combinação das duas formas de pesquisa ao invés de se abordar cada uma delas isoladamente (CRESWELL, 2010). Por tais razões e com a pretensão de se alcançar uma análise mais profícua do tema, o procedimento de pesquisa adotado foi o quantitativo e o qualitativo. 


\subsection{CAMPO DA PESQUISA}

A pesquisa foi realizada no Instituto Federal de Educação, Ciência e Tecnologia do Ceará, campus Acaraú, nas comunidades e em escolas públicas de ensino médio do município de Acaraú e seus Distritos.

A escolha do campus se deu em função do vínculo que tem a pesquisadora com esta Instituição: servidora técnico-administrativo desde outubro de 2014. Ademais, considerando os objetivos da Portaria $\mathrm{n}^{\circ}$ 7, de 22 de junho de 2009, do Ministério da Educação (MEC), o produto técnico relacionado ao tema do estudo deve, necessariamente, ser aplicado na Instituição onde a pesquisadora está lotada, justificando-se, assim, a escolha.

\subsection{POPULAÇÃO/PARTICIPANTES}

A população pesquisada compreende:

\section{a) Estudantes do $3^{\circ}$ ano do Ensino Médio das Escolas Públicas de Acaraú:}

O objetivo em relação a essa amostra é identificar se os concluintes do $3^{\circ}$ ano do Ensino Médio das Escolas Públicas de Acaraú se interessam por cursos técnicos, em especial, pelo Curso Técnico em Pesca.

O Município de Acaraú possui 05 (cinco) escolas públicas estaduais de Ensino Médio: Liceu de Acaraú Maria Alice Ramos Gomes (sede de Acaraú), Tomaz Pompeu de Sousa Brasil (sede de Acaraú), Vicente de Paulo da Costa (distrito de Juritianha), Maria Conceição de Araújo (distrito de Aranaú) e Marta Maria Giffoni de Sousa (sede de Acaraú). Esta última, por ofertar educação profissional, não integrou a pesquisa.

Com a finalidade de delimitar a amostra dos alunos, obteve-se junto à CREDE 3, Coordenadoria Regional de Desenvolvimento da Educação, subordinada à Secretaria de Educação do estado do Ceará, a discriminação das escolas, seus respectivos períodos e a estimativa de alunos ingressantes no $3^{\circ}$ ano do Ensino Médio de $2015^{8}$.

\footnotetext{
${ }^{8}$ Dados fornecidos por e-mail, em 04 de dezembro de 2014, pela CREDE 3. O número de alunos na referida relação foi estimado, pois o prazo para encerramento de novas matrículas e transferência dar-se-ia apenas ao final de fevereiro de 2015.
} 
Considerando que o total de alunos estimado para cursar o $3^{\circ}$ ano do ensino médio em 2015 representou um universo muito amplo - 790 - optou-se por trabalhar com uma turma por turno, em cada uma das quatro escolas pesquisadas.

b) Genitores ou responsáveis legais dos estudantes do $3^{\circ}$ ano do Ensino Médio das Escolas Públicas Estaduais de Ensino Médio de Acaraú

O acesso aos pais tem por objetivo analisar a percepção destes sobre a profissão de pescador e suas principais dificuldades.

\section{c) Servidores do IFCE (docentes e técnicos) e do MEC}

A escolha dos servidores do campus entre os participantes tem por objetivo levantar informações sobre a implantação e oferta do curso, bem como identificar o cenário atual de sua oferta.

Além disso, inclui-se também entre os participantes um servidor do MEC/SETEC envolvido com as políticas públicas.

\subsection{DESCRIÇÃO DOS INSTRUMENTOS}

Como instrumentos, optou-se pela utilização de questionário estruturado e entrevista semiestruturada para a coleta de dados.

O questionário estruturado, que consiste na abordagem quantitativa, foi o instrumento escolhido para os alunos. Contemplou questões fechadas, complementadas por abertas, com o intuito de revelar informações não previstas inicialmente e que eventualmente pudessem aprofundar o objeto de estudo, enriquecendo, assim, a investigação. Para tanto, o instrumento reuniu questões ligadas aos cursos de preferência dos participantes e, também, questões relacionadas à divulgação do curso de pesca pelo IFCE.

$\mathrm{O}$ instrumento destinado à coleta de dados dos pais dos alunos e servidores técnicos do Curso Técnico de Nível Médio Subsequente em Pesca foi a entrevista semiestruturada, que consistiu na abordagem qualitativa, constituída por um roteiro 
flexível - apenas como condução e direcionamento - com o objetivo de propiciar ao entrevistado maior liberdade em sua fala.

Em relação aos pais, buscou-se a opinião destes sobre: a valorização ou não do pescador pela sociedade, a atividade da pesca e o futuro dos filhos.

Quanto aos servidores, o objetivo foi levantar informações sobre a implantação e oferta do Curso Técnico de Nível Médio Subsequente em Pesca, bem como identificar o cenário atual da oferta, com ênfase nas questões de estrutura física, corpo docente e divulgação do curso.

\subsection{PROCEDIMENTOS}

A pesquisadora iniciou suas atividades profissionais no IFCE/campus Acaraú em outubro de 2014 e verificou que na primeira formatura dos cursos técnicos da qual participou, em dezembro de 2014, havia apenas um formando no curso de pesca (turma 2012.2). O quantitativo inexpressivo despertou a sua curiosidade e levou-a a indagar aos servidores de seu setor (Coordenação Técnico-Pedagógica) o porquê de um número tão baixo. A partir de algumas respostas inferiu que à sua frente delineava-se um problema que urgia ser investigado, vez que causava - e ainda causa - preocupação aos gestores da Instituição: a baixa demanda do curso de pesca.

Iniciou-se, assim, a pesquisa. Primeiramente foi realizada uma revisão teórica sobre o tema, visitas exploratórias aos setores ligados à pesca - secretaria de agricultura e pesca, colônia de pescadores, indústria de beneficiamento de pescado - e biblioteca pública, no intuito de se obter registros históricos sobre a vocação do município na área de pesca. Ato contínuo, elaborou-se a construção dos instrumentos de pesquisa.

Realizou-se um pré-teste do questionário com 11 alunos dos primeiro semestre dos cursos técnicos do campus do IFCE, os quais afirmaram não terem encontrado dificuldades quanto à compreensão ou preenchimento do instrumento.

Objetivando abarcar o maior número possível de alunos, optou-se pela aplicação de questionário a esse público. Após obter autorização da Coordenadora da CREDE 3, Prof. Elvira Maria Fernandes Veras, para realizar a pesquisa nas escolas citadas, a 
pesquisadora contatou pessoalmente todos os diretores das escolas envolvidas para agendar as datas de aplicação do instrumento.

A coleta de dados nas escolas se deu no período de 14 de maio a 18 de junho de 2015, nos turnos matutino, vespertino e noturno (1 turma por turno), durante o horário de aulas. A amostra não foi aleatória, mas sim por conveniência. As turmas foram escolhidas pelo diretor de cada escola, seguindo a recomendação da pesquisadora para que a escolha recaísse, se possível, na turma mais numerosa. A entrada em sala foi previamente acertada com o professor da turma, que auxiliou a pesquisadora na distribuição e recolhimento dos questionários.

A finalidade e a importância da pesquisa foram esclarecidas aos alunos. Ato contínuo, explicou-se o desdobramento da fase seguinte: entrevista com os pais, após prévio contato e agendamento com o aluno. Em seguida, foi lido e explicado o termo de consentimento livre e esclarecido - TCLE, documento esse previamente assinado pela pesquisadora e seu orientador. Nenhum dos alunos presentes em sala, em todas as escolas visitadas, se recusou a participar.

A duração da aplicação do instrumento variou conforme o número de participantes, mas em média concluiu-se em 40 minutos.

Notou-se diferença de comportamento entre os alunos pesquisados. Os da zona rural (Aranaú e Juritianha) se mostraram mais receptivos e comportados do que os alunos das escolas localizadas na sede. Na maioria das turmas das escolas Tomaz Pompeu de Souza Brasil e Liceu de Acaraú Maria Alice Gomes, escolas da sede, houve muita algazarra e desatenção no preenchimento do questionário. Isso não se aplicou às turmas de EJA, provavelmente por serem alunos de idade mais elevada.

Das três localidades visitadas, Aranaú é a que se destaca pela pobreza e descaso governamental. A despeito desse fato, dentre as escolas pesquisadas foi a que mais impressionou positivamente a pesquisadora, visto ser uma escola receptiva, acolhedora e organizada.

A instituição possui baixo índice de violência e existe um forte vínculo afetivo entre professores, funcionários e alunos, provavelmente por se tratar de escola inserida numa comunidade pequena, onde todos se conhecem. $\mathrm{O}$ acompanhamento individual 
dos alunos efetivamente acontece. Os professores conhecem os pais dos alunos e os visitam habitualmente.

Segundo o Diretor, cortes orçamentários exigiram otimização dos recursos, adaptação de processos e da logística. Os espaços de convivência foram construídos pelos alunos e professores com material de refugo. A escola possui jardins repletos de flores, suspensos por garrafas pet. Os materiais de limpeza são feitos na própria escola pelo professor de química e alunos.

Além disso, apesar do valor absurdamente baixo da merenda por aluno $(0,34$ centavos), a escola consegue oferecer uma alimentação natural, com cardápio variado: canja, sopa de feijão, de carne, arroz com ovos, cuscuz com ovos, arroz com frango (Maria Isabel), vitamina (polpa natural de caju, goiaba, abacaxi ou tamarindo), leite, achocolatado, biscoito e mingau doce. No caso das verduras, $20 \%$ é proveniente da horta da própria escola e o restante da agricultura familiar, que fornece itens a preços baixos e com alta qualidade.

Apesar de enfrentar graves problemas, entre os quais se pode citar: orçamento reduzido, ausência de sinal de telefone na cidade, períodos longos sem internet e transporte descontínuo dos alunos - o que implica em evasão noturna de 50\% e não cumprimento dos dias letivos - a escola sobrevive de forma digna, honrando a educação.

No total, foram aplicados 253 questionários nas 4 escolas pesquisadas. Desse número, 52 alunos concordaram com a entrevista dos pais.

Surpreendeu a pesquisadora o baixo número de alunos que aquiesceram com a entrevista de seus genitores. Uma possível explicação para o fato seria a desconfiança. Já para alguns professores, quando indagados pela pesquisadora, disseram tratar-se, basicamente, de falta de interesse. Um deles, curiosamente, citou a preguiça como real motivo desse fenômeno.

Outra questão que merece registro é o baixo nível educacional de parte dos alunos pesquisados. Notou-se que muitos deles, apesar de se encontrarem na etapa final do ensino médio, mal sabem ler e escrever. Houve um número bastante expressivo de erros gramaticais, ortográficos e de concordância, nas respostas do tipo aberta. 
As entrevistas com os pais foram realizadas nas três localidades: sede do Município de Acaraú e Distritos de Aranaú e Juritianha (zona rural). O primeiro distrito fica a aproximadamente $26 \mathrm{~km}$ da sede e o segundo $15 \mathrm{~km}$. Ambos possuem várias comunidades, algumas de difícil acesso. A falta de pavimentação e o terreno arenoso dificultaram a locomoção. O trecho mais crítico compreendeu aproximadamente $9 \mathrm{~km}$ antes da chegada em Aranaú, uma estrada de péssima qualidade cujo pavimento se transformou em enormes buracos. O breve percurso de $9 \mathrm{~km}$ que em tese demoraria alguns minutos transformou-se em uma jornada estressante e perigosa de 45 minutos.

Tentou-se, por várias vezes, entrevistar os pais na própria escola, mas todas tentativas restaram frustradas em razão da falta de compromisso dos alunos contatados. $\mathrm{O}$ que se mostrou eficaz foram as visitas às residências sem prévio agendamento, sempre acompanhadas de alguns alunos que se dispuseram a ajudar a pesquisadora na localização dos endereços.

A maioria dos pais entrevistados mostrou-se, num primeiro momento, desconfiada com a inesperada visita. Alguns acharam que se tratava de alguma fiscalização relacionada ao bolsa família, benefício governamental de transferência de renda destinado às pessoas em estado de pobreza. Por essa razão a pesquisadora deixou de perguntar a renda familiar dos entrevistados, a fim de não comprometer a entrevista. Após a "quebra de gelo" as pessoas entrevistadas se mostraram cooperativas.

A finalidade da pesquisa e o objetivo da visita foram explicados e, em seguida, colheu-se a assinatura dos participantes no TCLE. Alguns entrevistados não são escolarizados, contudo fizeram questão de apor seu nome nos termos de consentimento, a despeito da demora e relativa dificuldade.

Todas as entrevistas foram gravadas com a aquiescência dos participantes. Foram entrevistados 25 pais, sendo 11 homens e 14 mulheres. Em relação aos homens, 5 pescadores, 2 ex-pescadores, 1 motorista de ambulância, 1 representante de vendas, 1 eletricista e 1 agricultor. Dentre as mulheres, 3 marisqueiras, 6 do lar, 1 vendedora de cosméticos, 1 professora, 2 agricultoras e 1 agente comunitária. Quanto à escolaridade, 7 analfabetos, 11 com ensino fundamental incompleto, 2 com ensino fundamental completo, 1 com ensino médio incompleto, 2 com ensino médio completo e 1 com ensino superior completo. 
Em relação às entrevistas dos servidores, docentes e técnicos administrativos do IFCE, foram adotados os mesmos procedimentos já relatados. Por se tratar de um público bem informado e de escolaridade elevada, não houve dificuldades nesse processo.

Existem atualmente no campus 52 professores e 40 Técnicos Administrativos. Foram entrevistados 12 servidores do IFCE: 8 docentes, 2 técnicos de laboratório (pesca), o Diretor do Campus e o Coordenador da Coordenação de Comunicação e Eventos. Além disso, foi entrevistado um servidor do Ministério da Educação, envolvido com Políticas Públicas.

As entrevistas foram realizadas no período de 09 de abril a 23 de setembro de 2015.

\subsection{TRATAMENTO DOS RESULTADOS}

Os dados coletados através do questionário foram lançados no programa Excel, quantificados e analisados por meio de gráficos.

As entrevistas, tanto dos servidores quanto dos pais, foram transcritas e, após a devida organização das falas, reduzidas em categorias de análise para melhor compreensão do todo, utilizando-se a técnica de análise de conteúdo proposta por Bardin (1977).

O material decorrente dos questionários e entrevistas compõem a sustentação empírica da investigação, analisada com base no referencial teórico e apresentada a seguir. 


\title{
5 A VISÃO DOS ATORES
}

\subsection{A VISÃO DOS ALUNOS}

A análise quantitativa foi realizada por meio de gráficos, ordenados conforme a numeração das questões do questionário estruturado, aplicado aos alunos do terceiro ano do ensino médio.

Com esse instrumento buscou-se averiguar se os alunos se interessam pelos cursos técnicos, em especial pelo curso de pesca, ou se preferem, como colocado nas hipóteses de trabalho, os cursos em nível de graduação. O questionário contemplou, ainda, por meio de questões fechadas, a possibilidade de se averiguar a eficácia da divulgação do curso junto às escolas nas quais o questionário foi aplicado.

O encerramento do ensino médio apresenta ao jovem prestes a adentrar na vida adulta uma série de desafios: continuar ou não os estudos, definir uma profissão, optar pelo ingresso imediato no mercado de trabalho ou por uma formação mais ampla, mediante o ingresso em universidade. Segundo Sparta e Gomes:

\begin{abstract}
A adolescência é uma fase da vida caracterizada por uma série de mudanças, não só fisiológicas, cognitivas e psicológicas, mas também em relação aos papéis sociais a serem assumidos pelo indivíduo. Entre eles, destaca-se o papel do trabalhador. O jovem brasileiro que chega ao fim do ensino médio é chamado a fazer escolhas profissionais e pode optar pela continuação dos estudos ou pelo ingresso imediato no mercado de trabalho. (SPARTA; GOMES, 2005, p. 47)
\end{abstract}

O indivíduo que concluir o ensino médio e optar pela continuidade dos estudos poderá ingressar tanto na educação profissional e tecnológica quanto na educação superior, conforme dispõe os artigos 39 e 44 da Lei no 9.394/96 - LDB.

Os alunos foram indagados (Gráfico 1) se, após o ensino médio, continuariam os seus estudos. O gráfico a seguir indica que 78,3\% deles responderam "sim"; 19,8\% "não sabem"; 1,6\% afirmaram que "não" e apenas 0,4\%, que refere-se a um aluno, "não respondeu" a questão. 


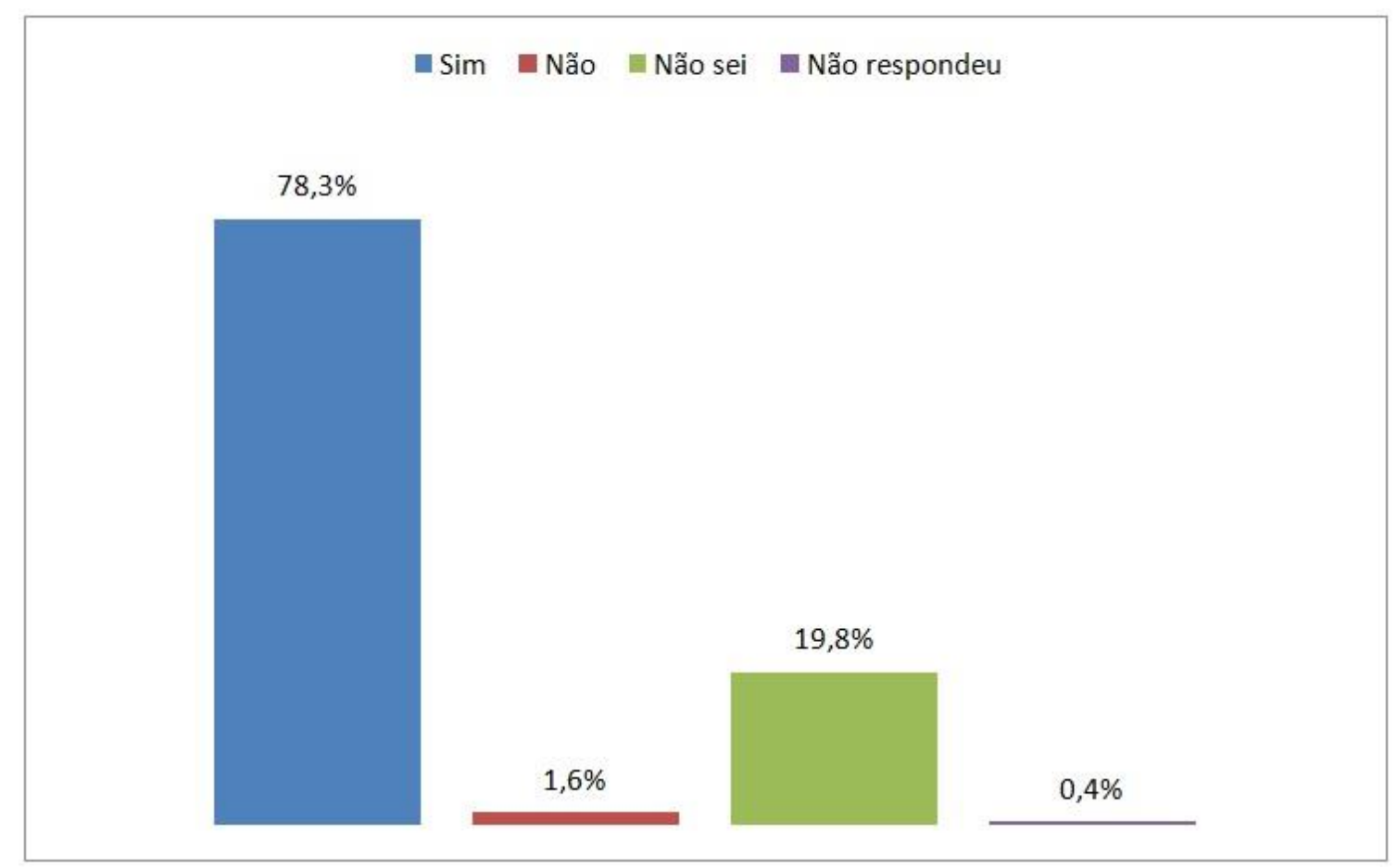

Gráfico 1: Continuação dos estudos após o ensino médio.

Os dados indicam que a maioria dos participantes $(78,3 \%)$ considera importante para suas vidas a formação por meio da escola. Observa-se, também, um número expressivo de alunos indecisos (19,8\%), provavelmente por entenderem o ingresso imediato no mercado de trabalho mais vantajoso que o aumento da trajetória formativa.

Outro aspecto investigado foi o curso desejado pelos alunos (Gráfico 2), independentemente das oportunidades educacionais existentes. Como trata-se de questão aberta e foram analisados 253 questionários - o que representa um universo bem expressivo -, o gráfico abaixo destaca apenas os percentuais referentes aos 10 cursos mais citados pelos entrevistados, além do percentual dos que não responderam a questão. 


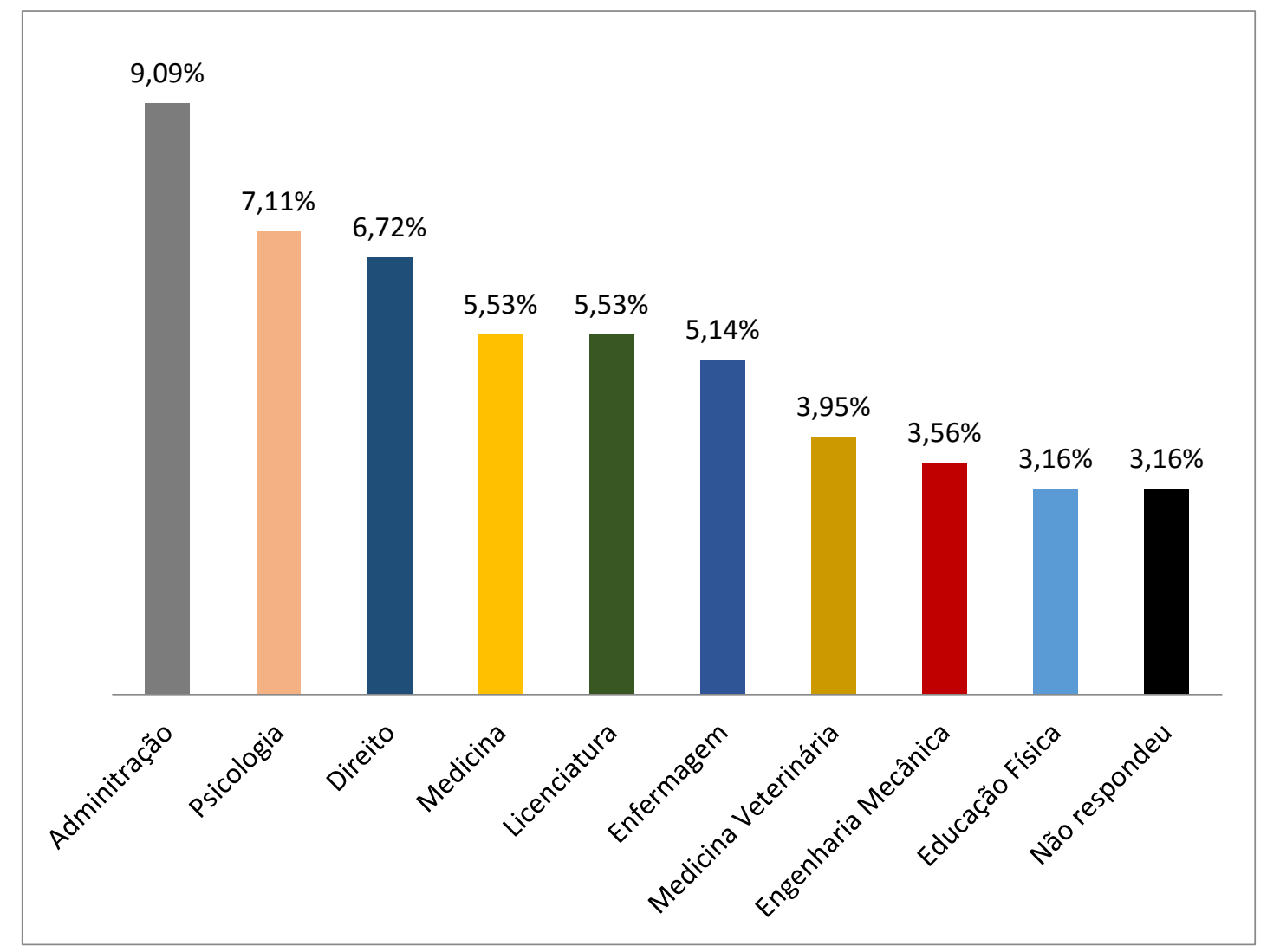

Gráfico 2: Curso desejado.

Os dados apontam uma possível preferência dos estudantes por cursos de graduação e historicamente de maior tradição, como se observa pelos quatro primeiros lugares, na seguinte ordem de preferência: Administração (9,09\%), Psicologia $(7,11 \%)$, Direito $(6,72 \%)$ e Medicina (5,53\%). Além disso, é manifesto o desinteresse dos participantes pelos cursos técnicos.

Sparta e Gomes discorrem sobre a tendência dos jovens, após a conclusão do ensino médio, de se decidirem por cursos mais tradicionais de graduação. A razão de tal predileção estaria, segundo eles, no próprio desenvolvimento histórico da educação brasileira:

Apesar da variedade de possibilidades para a continuação dos estudos existente no país, verifica-se uma tendência do jovem que termina o ensino médio de fazer escolhas profissionais ligadas aos cursos mais tradicionais de graduação oferecidos pela educação superior. Essa situação está diretamente ligada ao desenvolvimento histórico do ensino médio, da educação superior e da educação profissional em nosso país. (SPARTA; GOMES, 2005, p.47) 
Historicamente o ensino secundário objetivava a preparação dos jovens pertencentes à elite para o ingresso no ensino superior. $\mathrm{O}$ ensino técnicoprofissionalizante, por sua vez, tinha a atribuição de suprir a demanda de profissionalização das classes menos favorecidas da sociedade. Com o decorrer do tempo, o governo brasileiro, objetivando universalizar o ensino profissional e livrá-lo do estigma de ser um ensino inferior, definiu como uma das estratégias a criação dos cursos tecnológicos (educação profissional de ensino superior), todavia o preconceito persistiu e continua sendo uma questão de difícil solução (SPARTA; GOMES, 2005).

Alertam o autor, baseados em estudo de Lassance, Grocks e Francisco, que a valorização exacerbada do ensino superior, sobretudo dos cursos mais tradicionais, pode surtir efeitos negativos na formação dos jovens:

No entanto, segundo Lassance, Grocks e Francisco (1993), a entrada na universidade tem assumido para o jovem brasileiro um caráter de tarefa evolutiva em si mesma, como se o ingresso na educação superior fosse uma continuidade natural a ser assumida por quem termina o ensino médio e a única alternativa disponível de inserção no mundo do trabalho. Essa valorização do ensino superior, principalmente dos cursos mais tradicionais, vem exercendo influência negativa sobre as diretrizes do ensino médio, que vem deixando de lado o seu papel de preparação do jovem para o mundo adulto, conforme defendido pela LDB e se transformando em um veículo de preparação para o concurso vestibular (SPARTA; GOMES, 2005, p. 48).

Como desdobramento do gráfico abaixo (Gráfico 3), os cursos eleitos foram separados por sexo. 


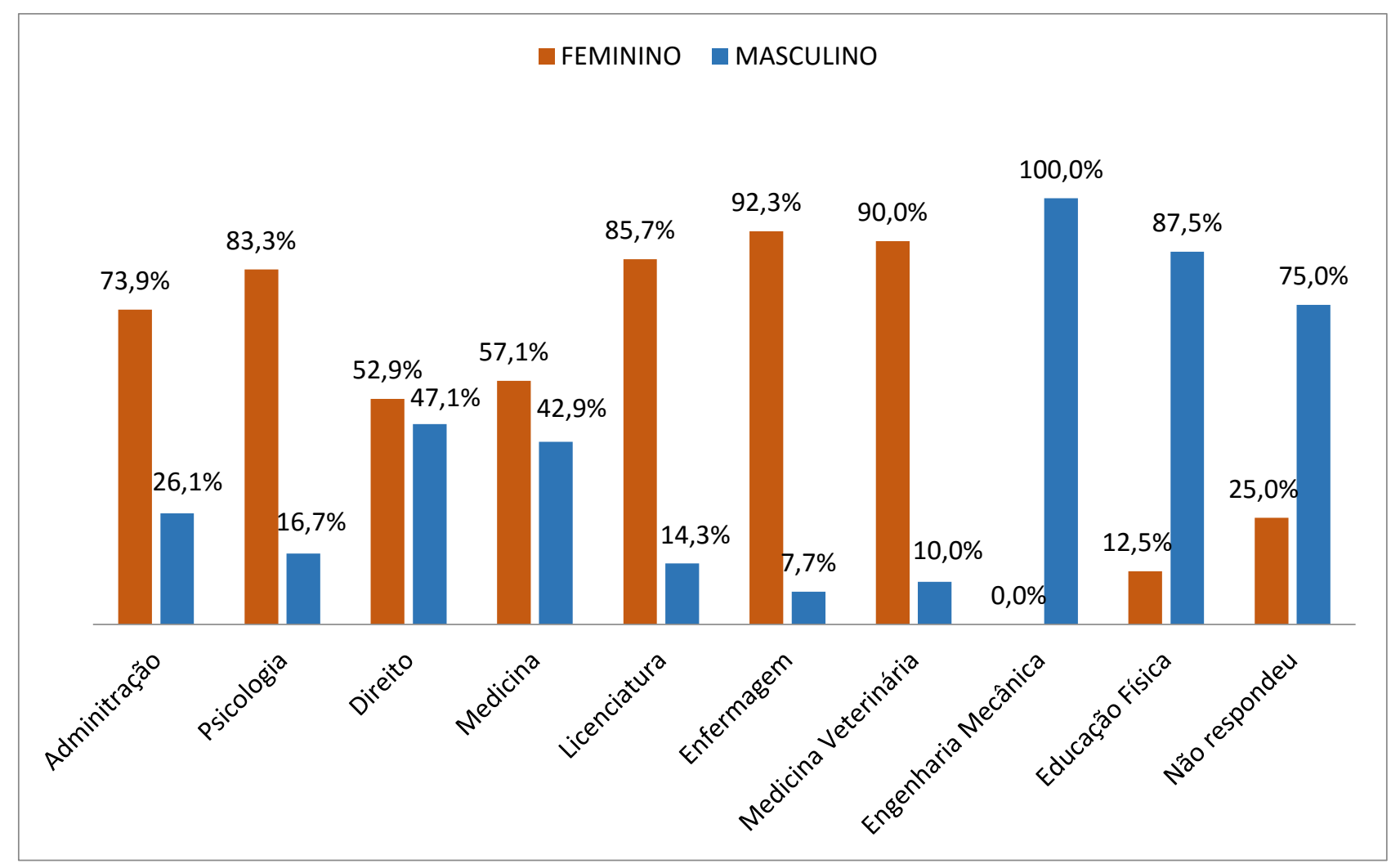

Gráfico 3: Curso desejado por sexo.

Neste gráfico, o percentual dos que não responderam revela um dado interessante: os homens se mostraram mais indecisos do que as mulheres em relação ao seu futuro profissional, excetuando-se, por óbvio, aqueles que não tenham respondido a questão porque optaram pela não continuidade dos estudos após o ensino médio. Outro aspecto a ser relevado é que nenhuma mulher optou por cursar Engenharia Mecânica, curso tradicionalmente ligado ao gênero masculino. Observa-se, também, que um percentual maior de mulheres em relação aos homens optaram por cursos nos quais geralmente estão presentes relações de afeto e troca, como Enfermagem, Licenciatura, Psicologia e Medicina.

Aos alunos foram apresentadas 4 alternativas de cursos (Gráfico 4): Bacharelado, Licenciatura, Tecnologia e Técnico Subsequente (nível médio). Indagouse aos mesmos qual seria a opção desejada. O gráfico abaixo demonstra que $68 \%$ dos participantes optaram pelo Bacharelado; $11 \%$ pela Licenciatura; $11 \%$ pelo Técnico Subsequente (nível médio); $8 \%$ pelo Tecnológico (técnico de nível superior); $2 \%$ não responderam. 


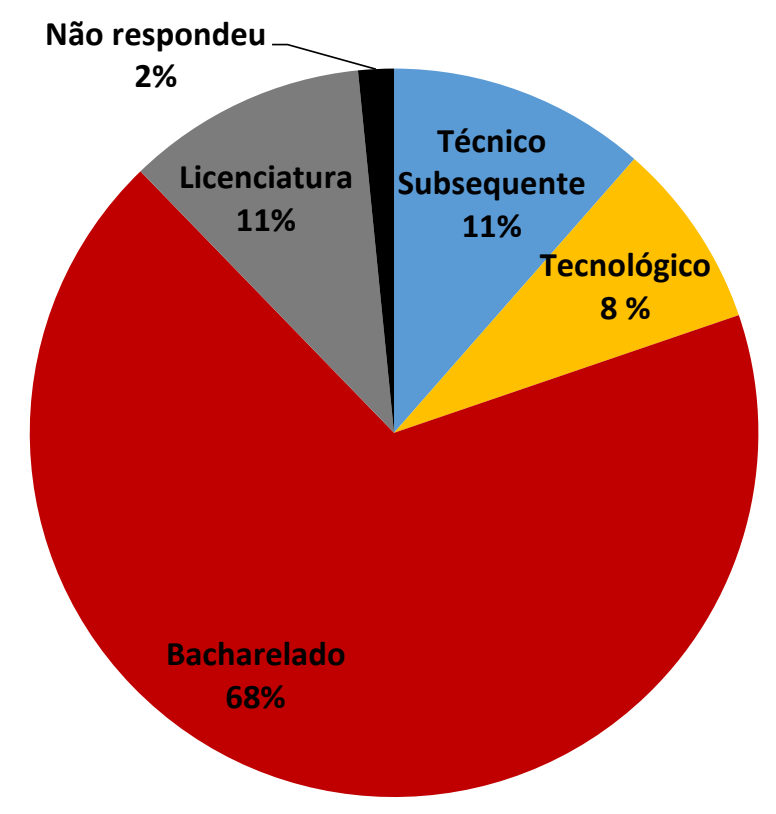

Gráfico 4: Alternativas após a conclusão do ensino médio: bacharelado, licenciatura, técnico e tecnólogo.

Novamente nota-se a preferência dos participantes pelo bacharelado, pois apenas $11 \%$ os participantes optou pelos cursos técnicos de nível médio. Uma hipótese passível de explicar essa inclinação pelos cursos de nível superior é o desejo de ascensão social dos participantes e a importância que atribuem a profissões de nível superior. Além disso, é possível que considerem desvantajoso investir o próprio tempo, no mínimo dois anos, em outro curso de nível igual ao que já obtiveram com a conclusão do nível médio.

Como desdobramento do Gráfico 4, solicitou-se aos participantes que justificassem a alternativa escolhida (Gráfico 5): bacharelado, licenciatura, técnico subsequente (nível médio) e tecnólogo (técnico de nível superior) As respostas mais recorrentes, agrupadas em categorias, foram: gostar/identificar com a área ou profissão $(37,9 \%)$; status ou recompensa financeira $(8,3 \%)$; solidariedade $(7,5 \%)$; formação mais ampla/faculdade (6,7\%); dúvida/indecisão $(6,7 \%)$; possibilidade de inserção no mercado de trabalho (4,7\%); sonho ou paixão $(4,0 \%)$; gostar de animais $(4,0 \%)$ e inovação $(2,8 \%)$. Houve, também, respostas incompreensíveis $(3,6 \%)$, questão sem resposta $(3,2 \%)$ e respostas ilegíveis $(1,6 \%)$. As respostas variadas foram categorizadas como "Outras" (9,1\%). 

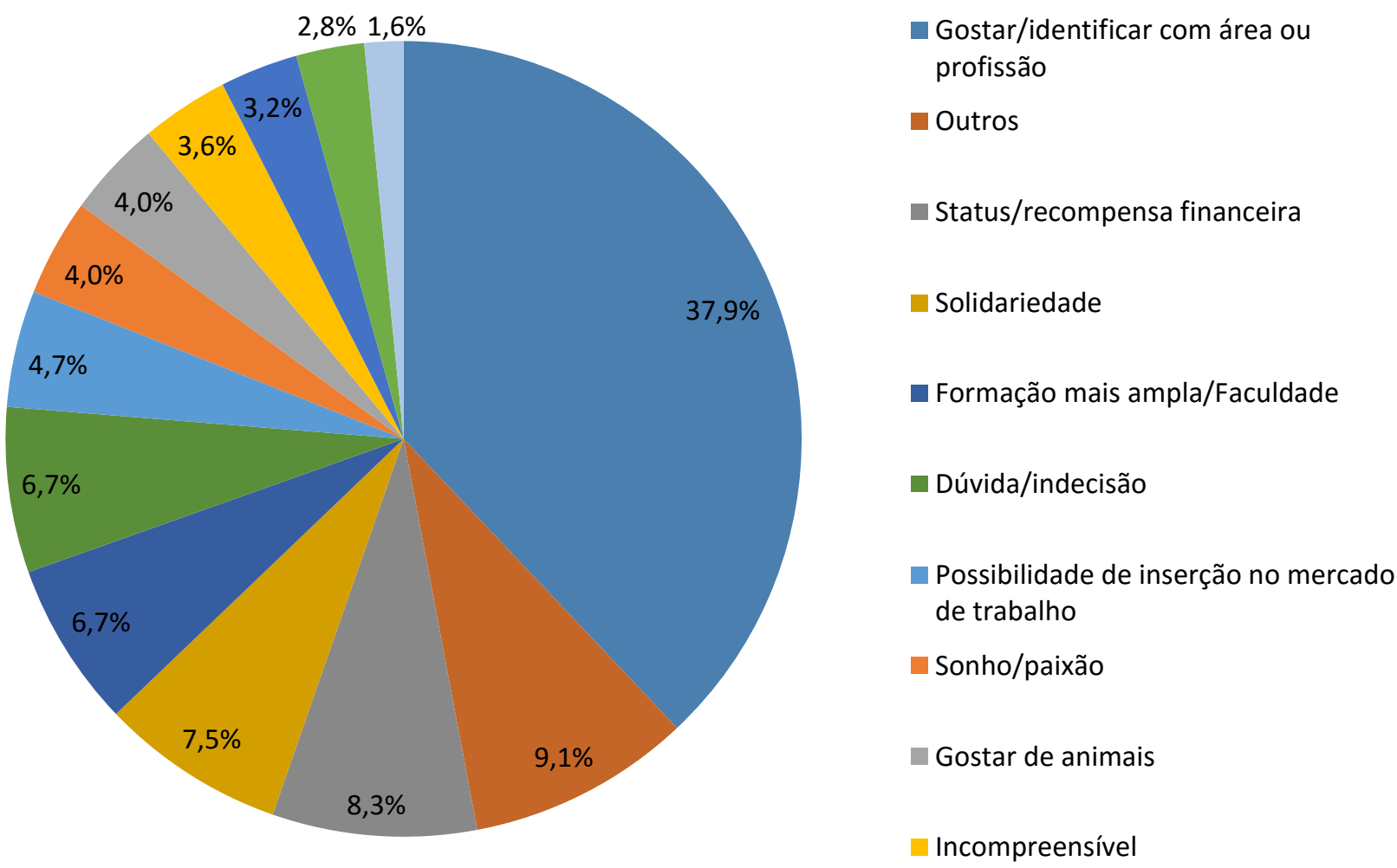

- Incompreensível

Gráfico 5: Justificativa do gráfico 4.

Os participantes foram indagados se conhecem o IFCE - Instituto Federal de Educação, Ciência e Tecnologia do Ceará (Gráfico 6): 72\% deles assinalaram “sim”; $25 \%$ "não" e 3\% não responderam. O percentual dos que afirmaram "sim" é significativo e indica que o campus é bem conhecido na região. Sua localização é estratégica, fica ao lado do fórum e a menos de um quilômetro das escolas Liceu de Acaraú Maria Alice Ramos Gomes e Tomaz Pompeu de Souza Brasil, fato que facilita a ida, para fins de visitação, dos estudantes dessas escolas ao IFCE/Campus Acaraú. 


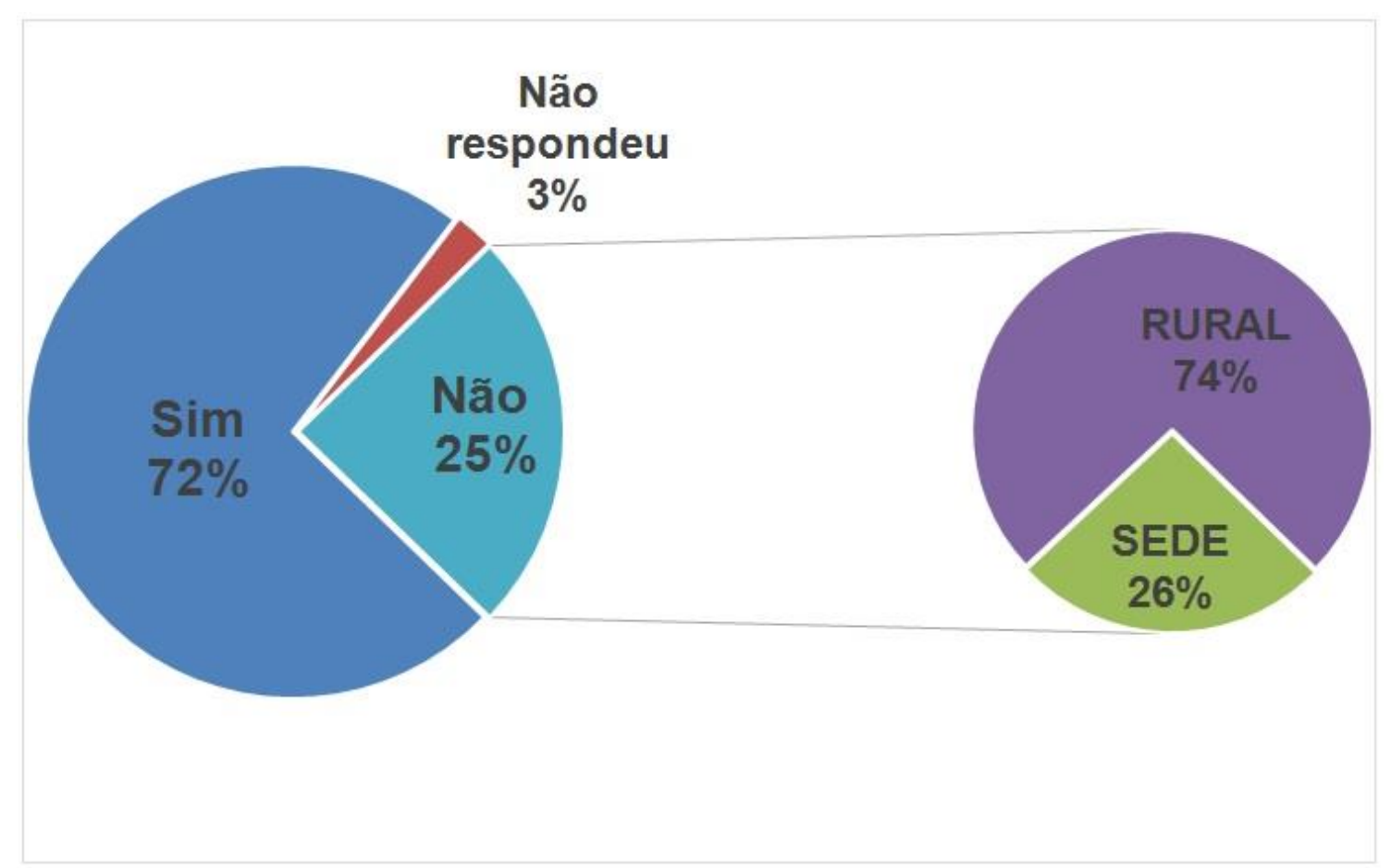

Gráfico 6: Conhece o IFCE?

Um dado que despertou atenção, e merece registro, é em relação ao percentual dos que afirmaram não conhecer o Instituto $-25 \%$. Desses $25 \%$ a maioria do alunos que desconhece o IFCE, 74\%, é da área rural (Distritos de Aranaú e Juritianha). Isso revela que uma possível deficiência no intercâmbio entre o Instituto e as escolas Maria da Conceição Araújo (Aranaú) e Vicente de Paulo da Costa (Juritianha), provavelmente em razão da distância entre essas localidades e o IFCE/Acaraú.

No item 5 do questionário, os alunos foram solicitados a manifestarem a sua escolha pelos 4 cursos técnicos subsequentes ofertados pelo IFCE (aquicultura, construção naval, pesca e restaurante e bar), em ordem de preferência (1, 2, 3 e 4, iniciando-se com 1 o de maior preferência). Foi-lhes dada, também, a opção de "nenhum", caso não houvesse interesse em cursá-los. O gráfico abaixo (Gráfico 7) mostra que $20 \%$ dos alunos não escolheriam nenhum dos 4 cursos ofertados. Os outros $20 \%$ representam as respostas incorretas por não obedecerem ao comando da questão, consideradas no gráfico abaixo como "inválidas". Neste caso incluem-se as respostas com preenchimento incorreto (apenas um ou dois cursos, assinalados com " $\mathrm{X}$ " e não com números). 


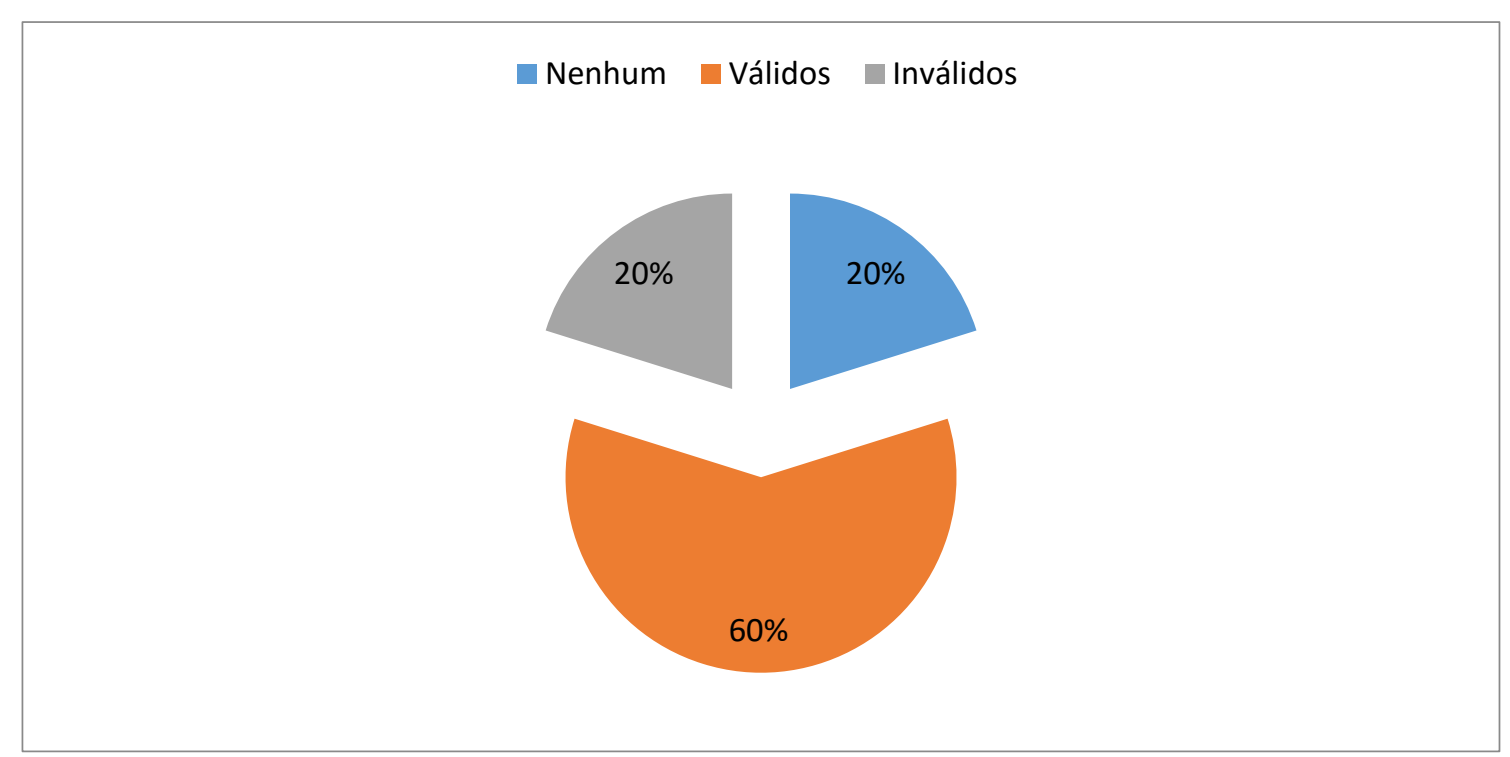

Gráfico 7: Respostas válidas, inválidas e opção “nenhum”.

No gráfico abaixo (Gráfico 8) observa-se que o Curso de Pesca lidera a $3^{\mathrm{a}}$ e a $4^{\mathrm{a}}$ opção na preferência dos alunos. Verificou-se, também, que ele figura em último lugar como a primeira opção dos alunos (13\%), demonstrando alta rejeição em relação aos demais cursos.

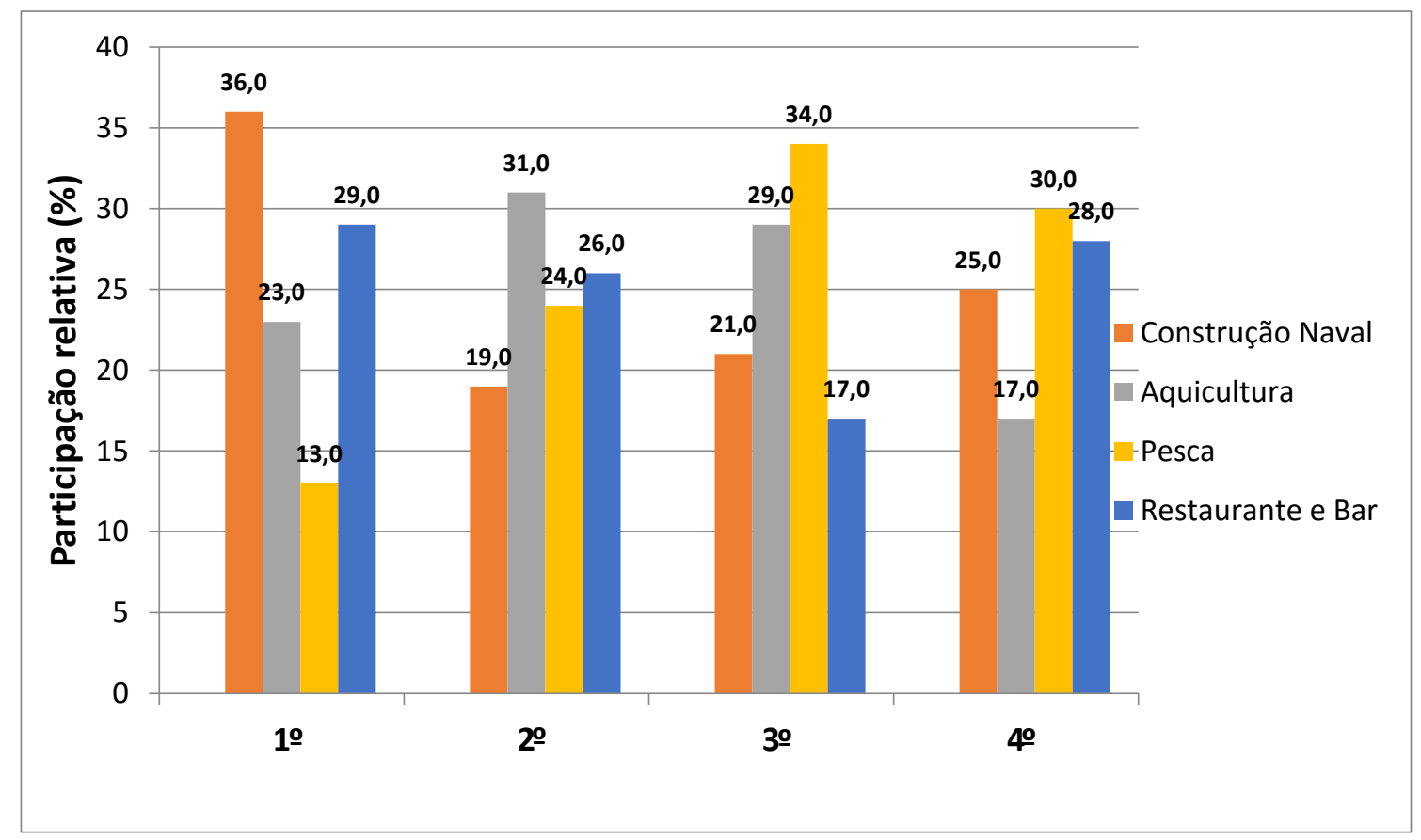

Gráfico 8: Escolhas dos cursos por ordem de preferência. 
$\mathrm{Na}$ questão 6, os alunos foram perguntados se conhecem o curso de pesca (Gráfico 9): 2,8\% dos pesquisados não responderam a questão; 13,4\% nunca ouviram falar; 64,4\% disseram que não o conhecem, mas já ouviram falar; $19 \%$ afirmaram que o conhecem razoavelmente e $0,4 \%$ afirmou conhecer o curso com profundidade.

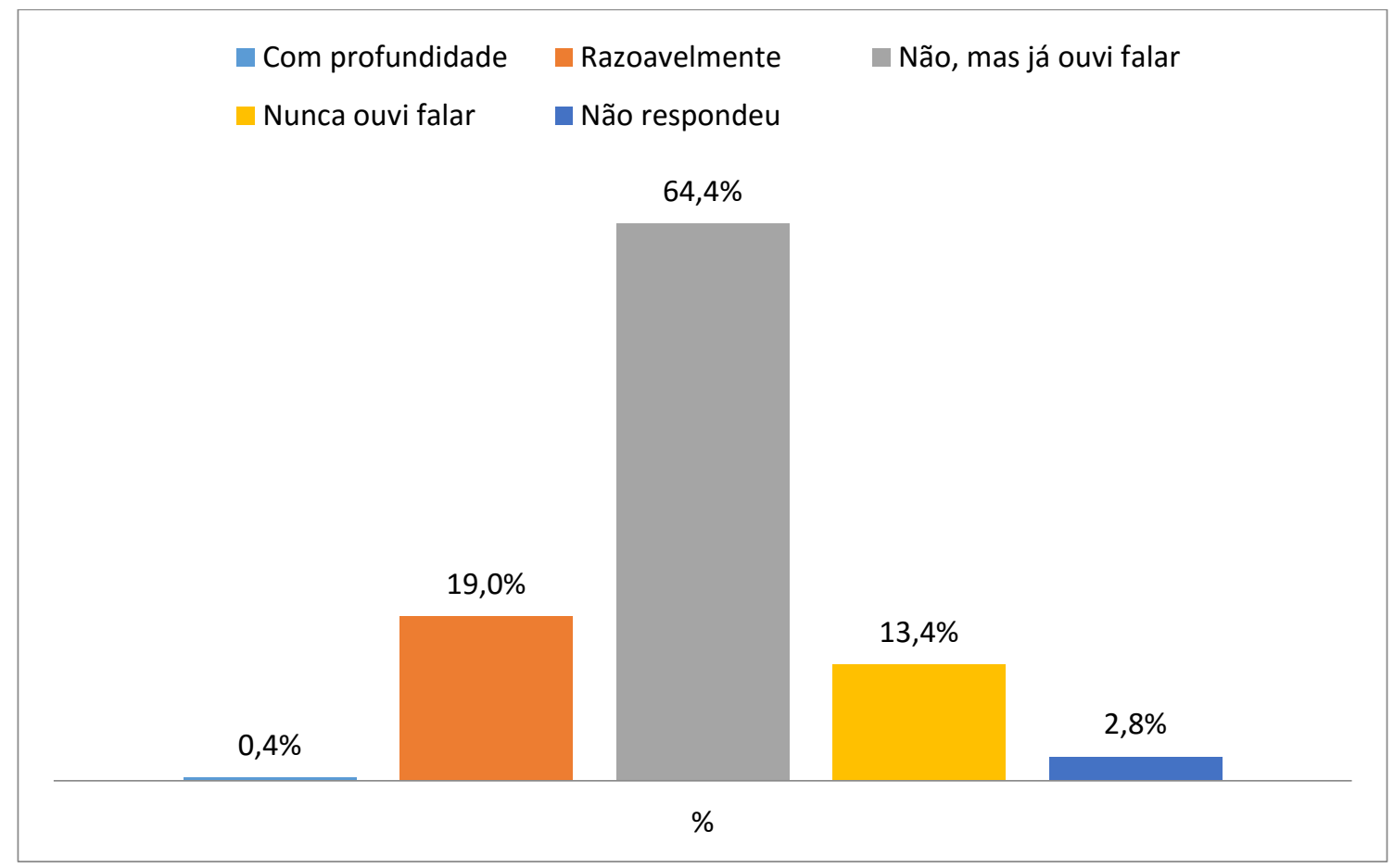

Gráfico 9: Você conhece o Curso Técnico em Pesca do IFCE?

Os dados indicam elevado número de alunos que não conhecem o curso $(13,4 \%$ e 64,4\%), o que sugere uma divulgação precária, especificamente em relação ao curso de pesca, e a necessidade de maior mobilização do Instituto nesse sentido.

Aos alunos que assinalaram "sim" na questão anterior (conhecem o curso de pesca), foi solicitado que apontassem por qual meio de comunicação chegaram a conhecê-lo (Gráfico 10). 


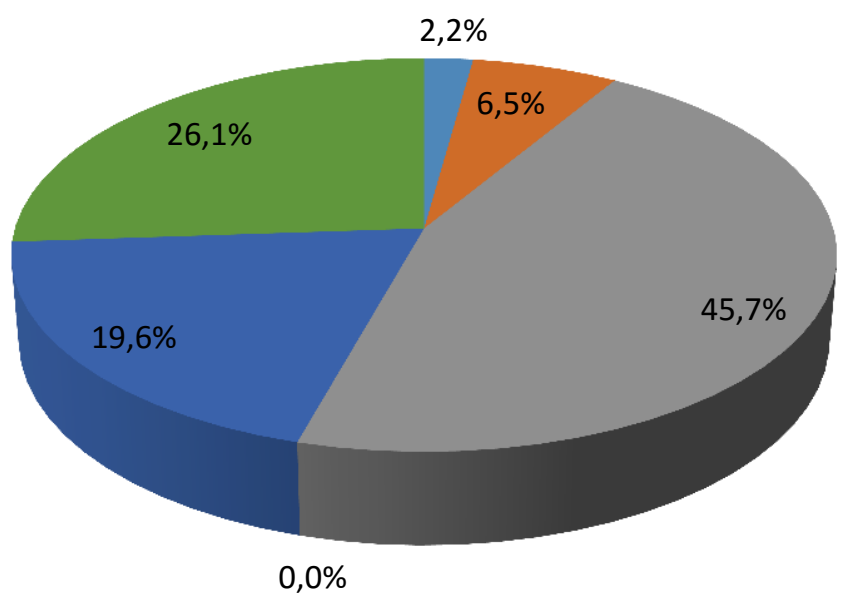

Rádio

Internet

Amigos ou parentes que estudam no IFCE

Cartazes pela cidade

Visita de sua escola ao campus

- Visita do IFCE na sua escola

Gráfico 10: meio de divulgação mais eficaz.

Contrariando expectativas da pesquisadora, o rádio, considerado um meio de comunicação bastante eficaz nas cidades do interior do estado, representou apenas 2,2\% das escolhas. Igualmente a internet, meio de comunicação de larga escala, foi o meio eleito por apenas $6,5 \%$ dos participantes. Quanto aos cartazes espalhados pela cidade não foi a escolha de nenhum dos participantes $(0,0 \%)$. O meio de comunicação mais eficaz foi o "boca a boca" de amigos ou parentes que estudam no Instituto $(45,7 \%)$, seguido de visita do IFCE nas escolas $(26,1 \%)$ e visita das escolas no campus $(19,6 \%)$.

Os dados indicam a necessidade de se aumentar a frequência de visitas às escolas e, também, a possibilidade de se definir estratégias de divulgação em conjunto com os próprios alunos, maiores responsáveis pela visibilidade do curso.

Quanto à questão de n. 8, indagou-se aos alunos, caso decidissem ingressar no curso de pesca, se os seus pais incentivariam tal decisão (Gráfico 11). 


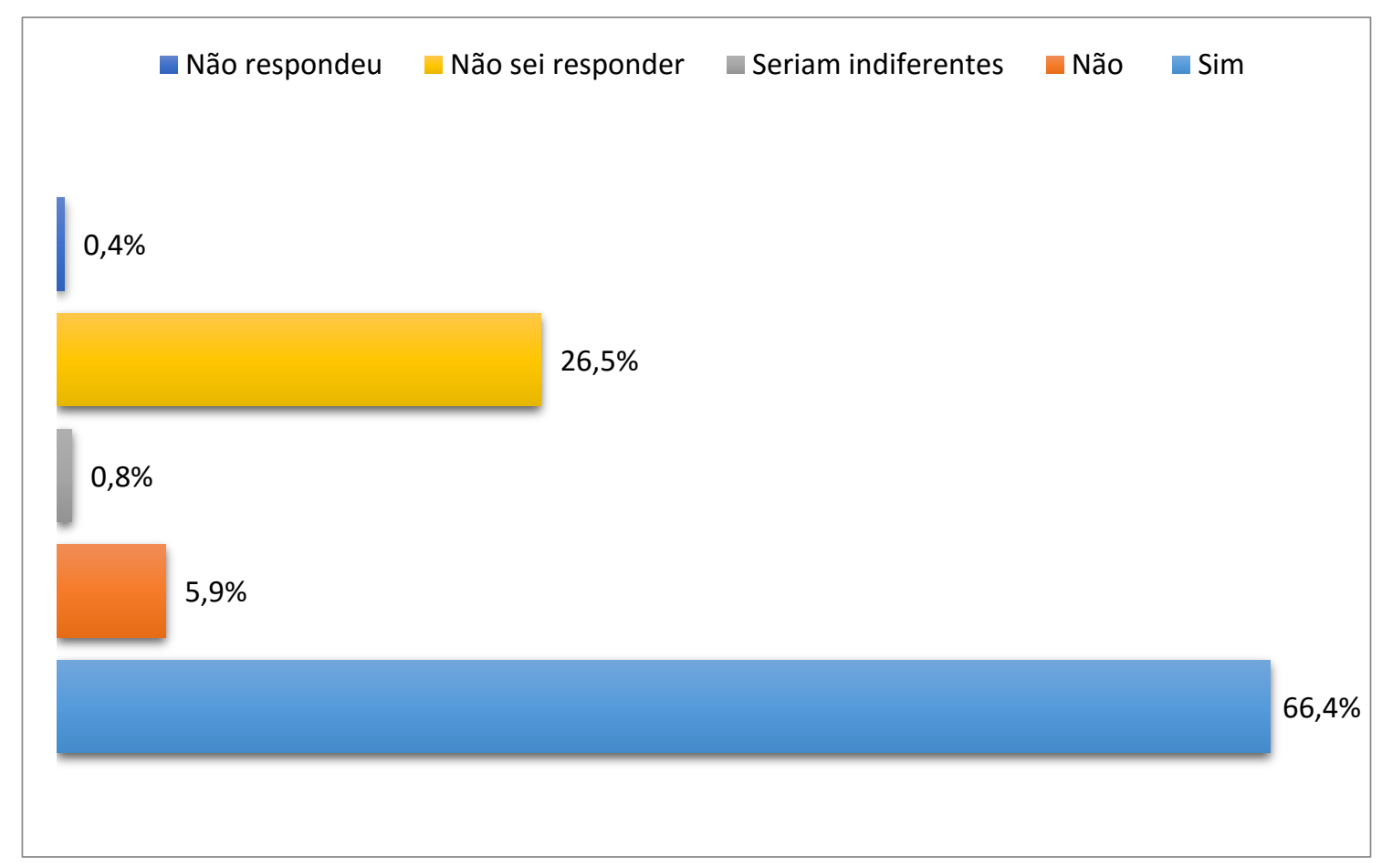

Gráfico 11: Se os pais incentivariam o ingresso dos filhos no curso de pesca.

A maioria dos participantes, 66,4\%, afirmou que sim; $26,5 \%$ não souberam responder; $5,9 \%$ disseram não; $0,8 \%$ afirmou que os pais seriam indiferentes e apenas $0,4 \%$ dos participantes não respondeu a questão.

O gráfico leva à presunção de que os alunos são apoiados pelos pais, provavelmente porque estes consideram relevante a autonomia dos filhos e respeitam as suas decisões.

Em relação à questão 9, se alguém da família do participante é pescador ou pescadora, esta foi construída apenas para que a pesquisadora tivesse conhecimento do grau de parentesco dos alunos com familiares pescadores, caso houvesse a necessidade de localizar e entrevistar um número maior de pais ou representantes legais pescadores (Gráfico 12). 


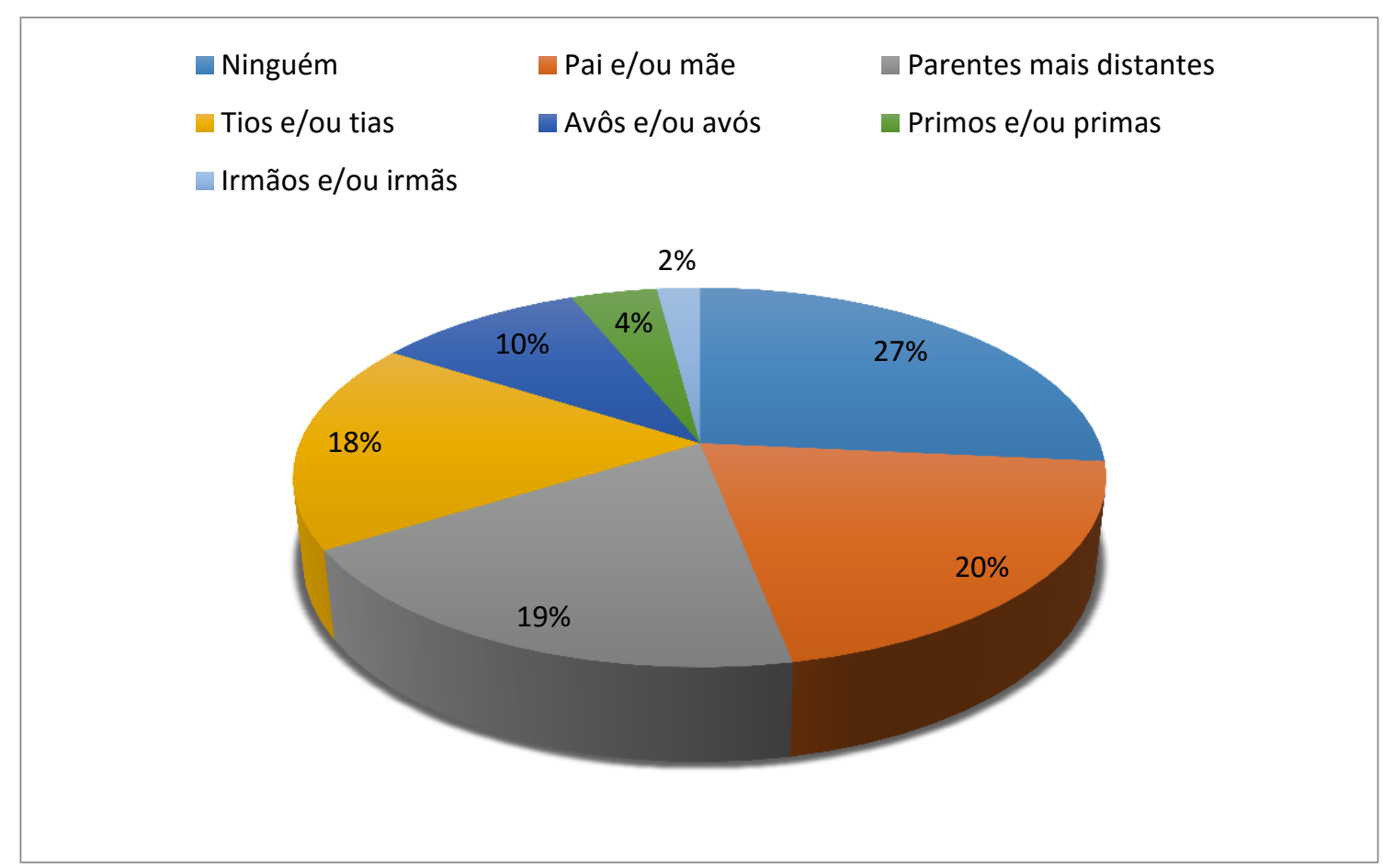

Gráfico 12: Alguém de sua família é pescador ou pescadora?

Apurou-se que $27 \%$ não possui nenhum familiar pescador; $20 \%$ possuem Pai e/ou Mãe; 19\% afirmaram ter parentes mais distantes; 18\% Tios e/ou Tias; $10 \%$ Avôs e/ou Avós; 4\% Primos e/ou Primas; 2\% Irmãos e/ou Irmãs. Os dados indicam um número expressivo de alunos que têm parentesco com pescadores (73\%).

Os dados que emergem da análise quantitativa indicam a preferência dos alunos por cursos de graduação ao invés dos cursos técnicos, pois a maioria optou pelo bacharelado. Em relação aos quatro cursos técnicos subsequentes ofertados pelo IFCE, os dados sugeriram alta rejeição ao curso de pesca e possível deficiência na divulgação do mesmo junto às escolas de ensino médio, sobretudo as localizadas na área rural (Aranaú e Juritianha). 


\subsection{A VISÃO DO GESTOR DO MEC, GENITORES E SERVIDORES DO IFCE}

Levando-se em conta que o objetivo geral desta pesquisa é analisar a oferta e a demanda do curso de pesca, optou-se pela divisão da abordagem qualitativa em duas partes: a primeira, relacionada à demanda (percepção dos pais sobre a profissão de pescador e suas principais dificuldades); a segunda, relacionada à oferta (opinião dos servidores sobre a escolha do curso e o seu cenário atual). Como impulso introdutório, ambas são precedidas da análise referente às políticas públicas no âmbito da educação profissional e tecnológica.

Os nomes dos entrevistados citados são fictícios.

\subsubsection{A visão do gestor do MEC}

Dentre as políticas públicas implementadas no Governo Lula, no âmbito da educação profissional, se destaca a Política para a Formação Humana na Área da Pesca Marinha, Continental e Aquicultura Familiar/Portos e Navegação.

A política pública em questão foi criada a partir do Termo de Cooperação Técnica $n^{\circ}$ 002, de 18 de dezembro de 2006, celebrado entre Ministério da Educação, por meio da Secretaria de Educação Profissional e Tecnológica - SETEC e a Secretaria Especial de Aquicultura e Pesca da Presidência da República, posteriormente transformada em Ministério da Pesca e Aquicultura, hoje extinto.

Indagado sobre qual seria o público alvo dessa política, o participante assim respondeu:

O ponto de partida são os pescadores, pescadoras, marisqueiros e marisqueiras, na área da pesca etc, essa gente que é o lombo da história desse país, invisível nas políticas públicas (...) a política de formação humana visava essas pessoas, resgatar do ostracismo essas pessoas por meio da valorização humana educacional (...). César.

A partir da assinatura do referido Termo de Cooperação, foram tomadas duas decisões importantes, afirma o entrevistado:

(...) aumentar o número de cursos técnicos na Rede Federal e criar 14 Núcleos de Pesquisa Aplicada - NUPA'S. César. 
Tais decisões, segundo o participante, configuraram-se as primeiras intenções governamentais no que se refere ao planejamento e estruturação de uma política voltada a área de pesca no âmbito da educação profissional (MEC/SETEC).

$\mathrm{O}$ entrevistado salienta que o Termo de Cooperação $\mathrm{n}^{\circ} 2$ foi um marco nas políticas públicas, pois o aumento quantitativo dos cursos técnicos propiciou benefícios educacionais a centenas de alunos:

(...) com a implantação dessa política de formação abriu-se o mercado de trabalho em todas as regiões do país. (...) tínhamos apenas 5 cursos, no máximo 120 alunos e não tínhamos 20 professores. Com a assinatura desse acordo importante com a coordenação chegamos em 2012 a 85 novos cursos técnicos, quase 8 mil e quinhentos alunos e 680 professores concursados. César.

Em relação aos citados Núcleos de Pesquisa Aplicada à Pesca e Aquicultura NUPA'S, estes tiveram a sua organização normatizada por Estatuto aprovado pela Portaria SETEC n 183 , de 23 de novembro de 2010 e têm por finalidade a promoção e o desenvolvimento da política para a formação humana na área da pesca marinha, interior, continental e aquicultura familiar/ portos e navegação. Ao todo são 30 NUPA's espalhados por todas as regiões do país.

Os núcleos de pesca foram definidos segundo alguns critérios: o potencial pesqueiro da região, a localização geográfica favorável ao desempenho da pesca, a representatividade das comunidades que dependem dessa atividade e as pessoas de baixa escolaridade nelas inseridas.

Como princípios mais relevantes dos NUPA's estão a inclusão social, a sustentabilidade ambiental, o reconhecimento e fortalecimento das culturas das comunidades tradicionais.

O entrevistado ressaltou a dinamicidade dos NUPA's, um ente de natureza eminentemente articuladora:

NUPA é um ente que está dentro dos institutos federais, ele é dinâmico e aberto, internamente dialoga e se articula com todos os órgãos dos institutos, com ensino, pesquisa e extensão e externamente se relaciona com as universidades, com os ministérios, centros de pesquisa, prefeituras, secretarias de pesca e principalmente com as colônias de pescadores. César. 
Como acentuou o participante, os NUPA's tem estreita relação com o tripé ensino, pesquisa e extensão e uma de suas funções principais é atuar, fundamentalmente, na produção e difusão do conhecimento e na transferência de tecnologias às comunidades que desenvolvem as atividades de pesca e aquicultura.

Outra função relevante desempenhada pelos NUPA's, além da articuladora, o entrevistado destacou a análise e o desenvolvimento de projetos de pesquisa, de caráter interdisciplinar, voltados à diversidade biológica e cultural dos ecossistemas onde há atividade pesqueira:

(...) ao todo foram realizados 108 projetos de pesquisa aplicada, todas publicadas, num investimento total de 5 milhões de reais. César.

Além das conquistas acima listadas, se sobressai da fala do entrevistado o curso de alfabetização para pescadores chamado "Pescando Cidadania", criado pelo NUPA do Rio Grande do Norte, cujo investimento foi de apenas 30 mil reais:

(...) entraram 120 pescadores, pescadoras e marisqueiros e marisqueiras, em 6 meses não saiu ninguém. Todos terminaram o curso sabendo ler e escrever e querendo aumentar sua trajetória formativa (...). César.

"Pescando a Cidadania" foi um trabalho de formação continuada, de alfabetização de adultos, desenvolvido no Município de Macau e seus distritos (RN) pelos profissionais do IFRN/Campus Macau e financiado pela SETEC/MEC.

O curso de 40 horas/aula foi organizado em 10 encontros e se adotou uma metodologia diferenciada, específica para a comunidade de pescadores, fundada em ensinamentos de Paulo Freire. A metodologia diferenciada se deve à consideração de aspectos relevantes do modo de vida dos pescadores, seus interesses e necessidades, como direitos e deveres do cidadão, educação ambiental e a saúde do pescador e das suas famílias.

O entrevistado salientou que:

O projeto "Pescando a Cidadania" (...) é uma política que vem resgatar uma dívida do estado brasileiro para com toda essa gente que antes era invisível por meio do processo educacional. César. 
Trata-se, portanto, de importante projeto que, além de resgatar a dignidade da pessoa por meio da alfabetização, tem uma particularidade muito especial: a inclusão social.

\subsubsection{A visão dos genitores}

A análise e interpretação das falas dos pais contribuirão para o esclarecimento de duas hipóteses de trabalho: 1) a baixa demanda se dá em função do não reconhecimento social e da marginalização do pescador e; 2) os pais ou responsáveis pelos alunos do Ensino Médio não estimulam a escolha pelo Curso Técnico de Nível Médio em Pesca, por não vislumbrarem perspectivas de futuro na área da pesca.

O roteiro de entrevista dos pais foi construído objetivando uma compreensão maior da realidade dessa amostra e contemplou perguntas concernentes à escolaridade e atividade profissional dos entrevistados, suas opiniões em relação à valorização do pescador, à sua profissão e principais dificuldades, bem como em relação ao futuro dos filhos. Agregando todas essas questões e, ainda, levando-se em conta as respostas dos entrevistados, chegou-se à eleição das seguintes categorias de análise: escolaridade, valorização da profissão, o futuro profissional do filho e atividade de pescador.

\section{a) Da Escolaridade}

A escolaridade das pessoas influencia diretamente na forma como elas veem a si mesmas e o mundo que as cerca, por isso se entendeu relevante conhecer esse dado do universo dos genitores dos alunos.

Dos 25 entrevistados, entre pais e mães, 7 se declararam analfabetos:

Pra dizer a verdade assim em colégio mesmo, eu nunca estudei não. Dona Marcilene, marisqueira, analfabeta.

Nunca estudei não. Seu Joaquim, pescador, analfabeto, 35 anos de profissão

Dentre os 7 não escolarizados, 3 são pescadores e 1 é marisqueira. Os números demonstram que a maior parte das pessoas analfabetas entrevistadas está ligada à atividade da pesca. 
Dados extraídos do Registro Geral da Pesca, RGP, indicam que apenas 0,19\% dos pescadores profissionais declarou ter nível superior completo, enquanto que $85,41 \%$ declararam possuir ensino fundamental incompleto, ressaltando-se que nessa faixa também estão inclusos os não alfabetizados.

À primeira vista pode causar estranheza pessoas com ensino fundamental incompleto e não alfabetizados encontrarem-se no mesmo grupo, porém quando se trata dessa categoria social - pescadores -, a "lógica" é perfeitamente compreensível, como se verá adiante.

Dos 25 entrevistados, 11 declararam terem concluído a primeira ou mais de uma série do ensino fundamental. Desses onze, 5 trabalham ou já trabalharam com a pesca: dois pescadores, dois ex pescadores e uma marisqueira. Seu João dos Milagres é um dos exemplos:

\begin{abstract}
Eu só estudei até a $2^{\mathrm{a}}$ série do primário, e nem cheguei a terminar, a concluir, aí fui, saí pra trabalhar no pesado mais o meu pai, mas eu, eu não me considero analfabeto, eu sei fazer meu nome, sei fazer...ler alguma coisa, porque tem muitos deles aí que são analfabetos mesmo né, muitos pescadores que não querem estudar nem pra fazer o nome, acham que não aprendem mais né. Seu João dos Milagres, pescador desde os 10 anos (aprendeu o ofício com o pai).
\end{abstract}

Todos que afirmaram possuir o fundamental incompleto não quiseram ler o termo de consentimento livre e esclarecido - TCLE. A maioria pediu à pesquisadora que explicasse o conteúdo, alguns pediram que fosse realizada a sua leitura e outros explicaram saber apenas "desenhar o nome". A não alfabetização foi constatada, sobretudo, no momento da colheita de suas respectivas assinaturas nos termos de consentimento, um processo deveras lento e dificultoso, bastante parecido, realmente, com o ato de "desenhar do nome". Assim, embora prevaleça para fins de tabulação a escolaridade declarada, a realidade mostra que na verdade a condição desses entrevistados é equiparada à não escolarização.

O Censo de 2010 apurou que aproximadamente $91 \%$ da população brasileira com dez anos ou mais de idade são alfabetizados. Isso significa que $9 \%$ da população não sabe ler e escrever. Se comparado esse percentual com o apresentado pelo RGP, constata-se um índice extremamente elevado de pescadores não alfabetizados. 
Tais percentuais se aproximam das informações prestadas em conversa informal pela Presidente da Colônia de Pescadores de Acaraú - Z2, que afirmou ser de $90 \%$ o índice de analfabetismo entre os pescadores da região.

Saraiva ao pesquisar a caracterização socioeconômica da pesca artesanal na Ilha dos Coqueiros em Acaraú, discorreu sobre os reflexos da baixa escolaridade dos pescadores no exercício de sua atividade:

\begin{abstract}
A baixa escolaridade dos pescadores afeta diretamente a atividade pesqueira à medida em que os mesmos possuem menor acesso às informações capazes de gerar benefícios vinculados à incorporação de novas tecnologias de captura, à melhoria da qualidade do pescado, à inibição da pesca predatória e à adoção de novas formas de comercialização, entre outros fatores. (SARAIVA, 2015, p. 44)
\end{abstract}

Projetos de alfabetização de pescadores como o "Pescando Letras" - executado através do Programa Brasil Alfabetizado, do Ministério da Educação - e o "Pescando Cidadania", desenvolvido pelo IFRN são exemplos de Políticas Públicas que podem transformar a realidade de uma comunidade de pescadores, contribuindo não apenas para a melhoria de vida dessa população mas também para o desenvolvimento sustentável da atividade pesqueira.

Uma questão relacionada à escolaridade chamou a atenção em algumas falas, merecendo destaque: a comparação que os pais fazem entre a oferta de educação na época deles e a atual, para os filhos. Reconhecem que hodiernamente existem muitas oportunidades de formação, inclusive acompanhadas de alguns benefícios, como o transporte e a merenda, no entanto, externaram seu desapontamento com o fato de os filhos não darem importância a isso:

No meu tempo não tinha... (escola) (..) às vezes tinha uma professora (...) ai a gente estudava nas casas, isso os pessoal antigo, já tudo faleceram, hoje é tudo diferente né, hoje o governo paga o menino pra estudar ainda e dá carro, e dá de comer, e os menino não querem estudar. Ainda e de primeiro no meu tempo não tinha essa arrumação, não tinha essa oportunidade que hoje tem. Seu Alonso, agricultor, pai de pescador, analfabeto.

Não dá nem pra eu dizer que eu estudei o $1^{\circ}$ ano (...) hoje tem muita facilidade pra pessoa estudar, mas naquele tempo era muito difícil, a gente frequentava uma escola quase daqui uma légua, de pés, a areia mesmo que fogo atolando aqui na perna, aí estudei aquelas cartilhas, que tinha aqueles negócio de assoletrar ...tinha palmatória, todas essas coisas tinha, aí veio uma moça do Acaraú pra ensinar as primeiras cartilhas né (...) só que essa moça só passou um mês (...) aí não veio mais, pronto aí ... acabou a escola. Dona Raimunda, agricultora, analfabeta, mãe de pescador. 


\section{b) Valorização da Profissão}

A maioria dos entrevistados afirmou, por diversas razões, não ser a profissão de pescador valorizada pela sociedade. As razões mais recorrentes estão ligadas à baixa remuneração que a atividade oferece, à não melhoria das condições de vida, ao não acesso a determinados certos benefícios sociais e a ausência de políticas públicas para essa categoria.

Abaixo, alguns relatos:

É porque não tem valor mesmo aqui, tem dias que a gente vai pegá o que comer, tem dia que vai passa 2, 3 dias pra fazer 5 real, 10 real, aí é melhor ficar dentro de casa limpando cajueiro. Seu Benedito, pescador há mais de 20 anos, aprendeu o ofício com o pai.

Eu acho não, pra mim não. Meu marido é pescador desde o tempo que a gente se ajuntou, tem uns quase 25 anos e era pra ter outra vida né, outra melhora, outra coisa e é a mesma coisa. Dona Maria, do lar, esposa de pescador.

Acaraú é uma região na qual a maioria dos pescadores atua de forma artesanal, ou seja, realiza uma pesca simples, autônoma, de pouca produção, a qual, quando não se destina à comercialização, serve ao consumo da própria família do pescador.

As falas do Seu Benedito e da Dona Maria retratam a baixa rentabilidade da atividade e o não desenvolvimento desta que leve à uma considerável melhora nas condições de vida dessa população.

Dona Valdete criticou a falta de amparo ao pescador na época do defeso:

\footnotetext{
Acho não (...) a gente sente necessidade né que exista, que cresça (...) pra você ter uma ideia pescador não tem um seguro desemprego né, por exemplo, não tá no tempo daquela pesca a gente fica a ver navios né (...). Valdete, marisqueira e filha de pescadores.
}

O período de defeso importa na paralisação temporária da pesca com o objetivo de assegurar a reprodução das espécies. Nesse, período, portanto, os pescadores são proibidos de pescar.

No intuito de garantir a reprodução dos estoques pesqueiros e, ao mesmo tempo, assegurar um rendimento ao pescador, este poderá receber do Ministério do Trabalho e Emprego, o seguro-desemprego, também conhecido como seguro-defeso. O referido benefício é pago em parcelas mensais, na quantia de um salário-mínimo, em número equivalente ao período de paralisação, desde que o interessado atenda as exigências legais da Instrução Normativa MPA nº6, de 29 de junho de 2012. Uma delas é a inscrição do pescador no RGP como Pescador Profissional Artesanal. 
A alegada falta de acesso aos benefícios sociais é algo recorrente entre os entrevistados:

\begin{abstract}
Nem um pouco, nada de valorizada não, não tem ajuda de ninguém, bem dizer ninguém, como aqui no Acaraú mesmo tem a Colônia, mas se você chegar e dizer assim...o pescador chegou quebrou o pé e for pra colônia pra receber o auxílio doença, você pode voltar pra casa, se você não tiver uma família que lhe ajude você passa fome, você passa fome (...). Seu Pedro, ex pescador.
\end{abstract}

Nós temos sim uma colônia de pescadores, (...) pra mim ela funciona na parte mais burocrática, porque eu acho que a parte que é na praticidade de lidar com relacionamento com o pescador e a sua profissão, isso não existe, fica a desejar, porque a colônia de pescadores já que se trata de uma entidade só para o pescador, deveria tratar, proteger, acolher, dar mais um suporte a mais pro pescador pra que ele tenha ânimo, mais ânimo de querer trabalhar, de poder trabalhar (...) Conceição, professora de ensino fundamental, filha de pai pescador, irmã de pescadores e mulher de ex pescador.

Com o advento da Constituição Federal de 1988 as Colônias de Pescadores foram equiparadas aos sindicatos, por força do parágrafo único, artigo $8^{\circ}$ da referida Carta Magna. A Lei 11.699, de 13 de junho de 2008, que regulamenta o referido dispositivo constitucional, dispõe que as colônias de pescadores são reconhecidas como órgãos de classe dos trabalhadores do setor artesanal da pesca, cabendo-lhes a defesa dos direitos e interesses dessa categoria.

Os pescadores residentes nas regiões visitadas estão representados pela Colônia Z2, com sede em Acaraú. Não se pode afirmar em que medida a Colônia dos Pescadores cumpre com as suas finalidades constitucionais de representação na defesa dos direitos e interesses dessa categoria, pois a percepção de benefícios sociais como o auxíliodoença, auxílio-reclusão ou aposentadoria, dependem de regular cadastramento do pescador nessa entidade e, também, do pagamento de uma contribuição mensal na ordem de $2 \%$ do valor de um salário mínimo.

Observa-se na fala dos entrevistados o não acesso a benefícios sociais básicos, o que configuraria, pelo menos em tese, não apenas a marginalização dessa categoria, mas também grave violação do princípio da dignidade da pessoa humana.

A percepção de desamparo ultrapassa a questão mais premente do simples recebimento - ou não - de um benefício social. Dona Conceição, talvez por ser a única entre os entrevistados com formação superior, enxerga além e expressa sua indignação pelo descaso do poder público ao não dirigir suas políticas para a categoria dos pescadores: 
(...) pescador aqui não tem valorização de nada, a valorização do pescador aqui é mínima, mínima das mínimas, (...) ele é pra ser visto como todas as outras profissões que merecem respeito né, (...) mas a valorização ao homem que pesca nenhuma, por parte dos nossos governantes é um descaso muito grande, eu não vejo nenhum movimento, eu não vejo nenhum apoio, eu não vejo nenhum auxilio, nada que tenha a favor do pescador. Conceição, professora de ensino fundamental, filha de pai pescador, irmã de pescadores e esposa de ex pescador.

Outro fator também recorrente à não valorização da profissão de pescador está ligado, para alguns entrevistados, à postura inadequada em sociedade do próprio pescador, resultante, sobretudo, do uso habitual de drogas ilícitas. Segundo os participantes, as substâncias químicas mais consumidas entre os pescadores são o álcool e o crack:

Acho que não, porque uma que ganha pouco né, e quem ganha muito também estraga, não valoriza. (...) quando chega estraga tudo com negócio de bebida, é a maioria né também já estão no caminho errado. (...) a maioria são cachaceiro né, a maioria bebe, gosta duma cana, quando chega do mar vão direto pros bar, por isso que eu digo assim. Dona Josiane, vendedora de cosméticos, irmã de pescadores.

(...) muitos deles recebem dinheiro, mas num dão valor ao que ganha né, gastam com negócio de bebida, droga aqui tem muita aqui (...) eles eram pra se valorizar mais no serviço deles (...) às vezes prefere gastar com bebida do que dá à própria alimentação de casa. Seu Roberval, motorista de ambulância, esposo de marisqueira.

(...) eles usam mais é coisa pesada como cocaína, como craque (...) esse craque que entrou aí foi pra destruir a vida de todo mundo. Seu Emanuel, ex pescador.

Droga né...droga principalmente no nosso lugar que é tão pequeno e é tão assim cheio dessas coisas. Dona Josiane, vendedora de cosméticos, irmã de pescadores. Dona Josiane, vendedora de cosméticos, irmã de pescadores.

Outro vício citado - que conspurca a imagem do pescador em sociedade contribuindo para a sua desvalorização -, é o envolvimento com a prostituição.

(...) inconscientemente eles recebem aquele trocadinho e muitos deles ao invés de vir pra casa, trazer esse trocado pra dentro de casa, pra família, pros filhos (...) esse trocadinho fica numa droga, num vício, numa bebida, esse trocadinho vai pra casa de prostituição (...) a realidade que eu vejo aqui na minha cidade é esta e aí a família sofre (...). Dona Conceição, professora de ensino fundamental, esposa de ex pescador. 
Os vários dias passados em alto-mar são a grande causa dessa problemática, segundo o discurso de um dos entrevistados, por isso quando os pescadores aportam o desejo mais premente é a busca da satisfação sexual valendo-se da prostituição:

(...) na hora que eles saem do barco mesmo já é em cima do dono pedindo uma mixaria ali, pedindo 100, 50 reais pra já pra ir beber ou comprar o vício dele, ir prum barzinho, um barzinho com mulheres só pra satisfazer a vontade deles que passa 30 dias no mar. Seu Pedro, ex pescador.

Houve casos de pais, entretanto - mesmo sendo em menor número, que manifestaram opinião contrária, afirmando ser a profissão de pescador valorizada pela sociedade:

É, eu acho que sim né, porque a pesca é que traz o produto né, pra gente se alimentar e vender (...). Dona Joanita, marisqueira.

Eu acho que sim né, porque negócio de pesca é um negócio muito importante né, se a gente não conseguisse pescar... certo que tem coisa pra comprar pra se comer, mas a gente pegando o peixe, conseguindo umas coisinhas, já é melhor porque já diminui, a gente já guarda um pouquinho do dinheiro pra outra coisa né, eu acho muito importante negócio de pesca, muito importante mesmo. Dona Marcilene, marisqueira, filha de pescadores.

É porque hoje o que tá dando mais é o mar assim né...porque o mar hoje é de onde traz o alimento pro pessoal (...). Seu Alonso, agricultor.

Pelo que se infere do discurso dos entrevistados, a valorização se dá mais em função da importância que tem o pescado para o sustento familiar e, consequentemente, para a redução das despesas domésticas, do que propriamente com a pessoa do pescador.

Notou-se a relevância que possui o pescado na sua alimentação diária dos entrevistados:

(...) o pescador pode não ter nada, mas ele tem a barriga cheia (...). (...) você come o peixe que você gosta, você come a anchova, você come a guarajuba, come o galo, a tainha, aqueles peixe mais de, como se diz, de primeira, você só come o ruim se você quiser, né, então você come do bom e do melhor e é vivo, não pega química nenhuma. Seu João dos Milagres, pesca desde os 10 anos, aprendeu o ofício com o pai. 
Segundo Maldonado o consumo regular de peixe representa a confirmação da autonomia do pescador:

Uma dieta sem pescado é comer de sertanejo, dieta de interiorano sujeito à patrão, que trabalha num ambiente passível de apropriação e divisão: a terra. (MALDONADO, 1986, p. 64)

Nesse sentido, Diegues (1983) ressalta que no ambiente marinho não há propriedade formal do que a natureza produz, fazendo referência especialmente aos peixes. Estes são apropriados por quem chegar primeiro, seja por aqueles que disponham de melhores instrumentos de trabalho para captura ou por aqueles que detenham conhecimento suficiente para pescá-los.

\section{c) O futuro profissional do filho}

Os genitores dos alunos foram perguntados sobre o que pensam do futuro profissional dos filhos em relação às seguintes questões: se incentivariam ou não o ingresso dos mesmos no curso de pesca; se seria melhor para o filho cursar uma universidade ou um curso técnico e, se pudessem escolher uma profissão para ele, qual seria.

A categoria em apreço se mostra relevante porque é a essência do que se pretendeu buscar junto aos participantes: saber se eles estimulam ou não os filhos a escolherem o curso de pesca. Essa questão está relacionada a uma das hipóteses de trabalho: "Os pais ou responsáveis pelos alunos do Ensino Médio não estimulam a escolha pelo Curso Técnico de Nível Médio em Pesca, por não vislumbrarem perspectivas de futuro na área da pesca".

As respostas oscilaram entre "sim" e "não". Para os que disseram "sim", embora tenha sido a menor parte dos entrevistados, importante se fazer uma ressalva: para eles "incentivo" é sinônimo de "apoio", embora tenham significados diversos. O primeiro vocábulo os remete à ideia de encorajar e o segundo de aceitar. Eis algumas respostas relacionadas ao "sim": 
De ela ir? Não, eu sou de acordo, ela pode ir. Seu Joaquim, pescador.

Sim, desde que ela dissesse assim, mãe eu quero, eu tô aqui pra isso, pra incentivar (...) se essa fosse a opção dela né (...), é o que vai fazer ela feliz, é o que ela vai trabalhar todos os dias, eu digo assim a gente tem que escolher uma coisa que a gente goste (...). Valdete, marisqueira.

É se for o gosto dela...eu aprovo né, se for o gosto dela, eu não vou obrigar ela a fazer uma coisa que ela não quer né, porque se você vai trabalhar numa coisa que você não gosta, ai nem prazer de trabalhar não tem né, (...) o que ela quiser eu aprovo, é professor, é pesca, é o que for, eu aprovo, sendo o gosto dela. Dona Marcilene, marisqueira.

Observa-se que os pais, afortunadamente, relacionam a escolha da profissão com felicidade, realização, prazer no sentido de se fazer o que gosta. Pode-se extrair das falas, também, uma preocupação com a autonomia dos filhos, com o fato deles serem os únicos responsáveis pela escolha do rumo que darão ao seu destino profissional.

Seu Joaquim e a Dona Marcilene foram questionados sobre a hipótese deles poderem escolher a profissão dos filhos. O primeiro assinalou a existência de profissões melhores do que a de pescador, a segunda optou por uma profissão na qual a filha pudesse trabalhar na sombra, sugerindo a lida árdua do pescador sob o sol:

Eu acho que outra profissão era melhor do que a pescaria, do que o curso de pescador né. Seu Joaquim, pescador.

Fosse por mim mesma eu mandava ela fazer um curso assim, pra trabalhar assim, de secretario num banco (...) se fosse por mim ela fazia um curso pra isso né, (...) porque a gente trabalhar no sol como eu fiz pra criar elas não é bom não, agora já trabalhar assim na sombra já é melhor né, pra mim o meu gosto era esse, mas não é minha vontade é o dela. Dona Marcilene, marisqueira.

Dona Valdete fora perguntada se ela alguma vez pensou na possibilidade de a filha cursar uma Universidade. Assim respondeu:

Não incentivei por conta da dificuldade de pagamento, hoje em dia o governo né, que agora esse ano deu uma apertada né, a gente vê pelo jornal e tudo, mas se eu tivesse como pagar, eu botava pra frente, tava em Fortaleza fazendo faculdade. Valdete, marisqueira.

Dentre os que disseram que não incentivariam o filho a ingressar no curso de pesca - representando a maior parte dos entrevistados -, eis algumas respostas:

Pesca? Não, sobre pesca não. Eu acho uma profissão perigosa, apesar que todas as profissões hoje é perigosa, qualquer tipo, qualquer atividade que a gente enfrentar, qualquer tipo de trabalho existe perigo, mas sobre pesca eu acho assim uma profissão muito perigosa, eu não aconselhava ele trabalhar nessa área não. Seu Adoniran, eletricista. 
Não, eu não queria, se fosse pra mim dizer assim vai meu filho, eu quero tu lá, eu não queria. (...) Dona Maria, do lar.

Não, porque não tem futuro não. Seu Benedito, Pescador.

Não, pesca eu não queria não, queria não que ele não gosta, ele não dá valor...ele não gosta do mar assim, quando ele entra na canoa ele já toma porre, ele não gosta não, agora o meu filho mais novo adora o mar, queria que ele fizesse outra coisa. Dona Rute, Agricultora, esposa de pescador.

Nem ele ia querer, acho que nem ele mesmo ia querer ser pescador (...) acho que ele ia procurar outro meio de ganhar melhor. Dona Josiane, vendedora de cosméticos.

Rapaz, eu na minha opinião, eu achava que ele escolhesse uma coisa melhor que desse futuro pra ele, tá entendendo (...) tamo aqui pra o que ele precisar né, agora se ele quiser mesmo aí ninguém pode obrigar uma pessoa, a pior coisa do mundo é você quer uma coisa e seus pais não aceitam. Pedro, ex pescador.

Das respostas extraem-se justificativas diversas (a pesca é perigosa, existem outros meios de se ganhar melhor etc), entretanto uma se repetiu: a de que não dá futuro. A maioria dos entrevistados têm relação direta ou indireta com a pesca: ou são pescadores, ou marisqueiras ou possuem algum parente que exerça esta atividade.

É compreensível, portanto, que os pais não desejem que os filhos exerçam uma profissão que não lhes garanta condições mínimas de vida, como se pôde observar da fala dos entrevistados, oferecendo indícios de que "Os pais ou responsáveis pelos alunos do Ensino Médio não estimulam a escolha pelo Curso Técnico de Nível Médio em Pesca, por não vislumbrarem perspectivas de futuro na área da pesca”.

Em relação às profissões desejadas pelos pais, que os filhos poderiam, em tese, seguir, algumas respostas:

Engenheiro naval. Seu Pedro, ex pescador.

Enfermeira. Dona Gervásia, do lar.

Trabalhar em mercantil, em farmácia, outras coisas por aí, mas pesca eu não queria não. Seu Benedito, Pescador.

Acho que professor, então, melhor assim ... estudar Direito né, quem é que não queria? Dona Josiane, vendedora de cosméticos.

Sempre eu digo a ele, Pedro meu filho se você não quer ir se embora pra assim estudar fora em outro canto, faça o curso de professor, a faculdadezinha de professor (...) porque o que tem aqui mais por perto é professor. Dona Rute, do lar, esposa de pescador. 
Se fosse pra eu optar eu optaria em ela se formar em professora, alguma coisa assim, ou então na área de saúde também, mas aí depende dela. Seu Lineu, representante de vendas.

Eu queria uma coisa assim mais maneira (...) num mercantil, numa farmácia, era isso que eu queria pra ele. Dona Maria, agricultora, esposa de pescador.

Nota-se, de um modo geral, que os pais não vislumbram perspectivas de futuro para os filhos em profissões que não lhes sejam familiares, que vão além das conhecidas de seu cotidiano, como trabalhar em mercantil (supermercado) ou em uma farmácia. Provavelmente isso se deva à baixa escolaridade da amostra, que não teve oportunidades educacionais e, consequentemente, fora impedida de substanciais conquistas no campo profissional.

Os entrevistados foram perguntados, também, se prefeririam que o filho fizesse um curso técnico ou ingressasse em uma universidade. A vontade de que fossem para universidade prevaleceu em relação aos cursos profissionalizantes, como se vê:

Eu achava melhor a universidade. Dona Rosenete, esposa de ex pescador.

Bom, um curso técnico é bom, sempre que a pessoa tem um técnico né, mas eu acho assim a universidade é bem mais aprimorada né, mais além. Dona Neide, agente comunitária, irmã de ex pescador.

Ele ir pra uma universidade, mas se bem que os cursos técnicos também são muito bons mas uma universidade pra mim seria o ideal (...) tem assim uma coisa mais estendida, mas ampla (...) mas se for da vontade deles um curso técnico, fica na vontade deles. Conceição, professora de ensino fundamental.

Faculdade acho que seria melhor. Dona Maria, agricultora, esposa de pescador.

Extrai-se dos relatos dos entrevistados que a maior parte dos entrevistados dá importância a uma formação mais ampla, mais aprimorada, como diz a Dona Neide. Indica, também, um possível desconhecimento sobre as oportunidades de trabalho e ascensão profissional que os cursos técnicos têm a oferecer.

Para alguns pais, como a Dona Neide, o curso escolhido pelo filho não é tão importante quanto o fato de o mesmo continuar inserido no âmbito escolar: 
Em menor número, o curso técnico pode ser útil, num primeiro momento, para incrementar o currículo e adquirir experiência e, posteriormente, servir de trampolim para universidade:

Eu acredito que a pessoa tem que ter um curso pra colocar no currículo, que é muito bom (....) a pessoa não pode parar de estudar, mesmo fazendo um curso, trabalhando, tem as horas de escolher a universidade. Seu Lineu, representante de vendas.

Outra questão destacada pelos pais é a falta de oportunidades quanto à empregabilidade na região:

(...) porque aqui mesmo no interior eu acho que num tem muito futuro aqui não. (...) se a pessoa for querer alguma coisa aqui tem que ir se embora, tem que ir pra Fortaleza. Seu Roberval, motorista de ambulância, esposo de marisqueira.

Bom, eu escolheria uma profissão que tivesse aqui na cidade, aqui na região, que desse emprego aqui né, (...) pra se formar numa coisa que não tem aqui acho mais difícil, só se ela sair da cidade. Seu Lineu, representante de vendas.

Segundo os participantes, para que os filhos sejam inseridos no mercado de trabalho não resta outra saída senão tentar uma colocação profissional na capital ou em outras cidades do Estado, se a formação se der em algo que não tem oportunidade em Acaraú.

\section{d) A atividade de pescador}

As razões que levam ao baixo interesse pelo curso de pesca podem estar associadas ao modo de vida dos pescadores e a uma possível influência dessa condição na escolha dos filhos por outros cursos que não o de pesca, motivo pelo qual fez-se necessário conhecer o cotidiano desses trabalhadores.

Os entrevistados afirmaram ser difícil a ocorrência na região de trabalho com registro em carteira. Alguns se intitularam trabalhadores avulsos:

(...) não é todo que trabalha de carteira assinada não, é difícil algum trabalhar de carteira assinada, é muito difícil. Dona Marcilene, marisqueira, filha de pescadores.

(...) eles não querem registrar porque aí eles perdem né, eles acham que perdem pagando direito o pescador, eles querem avulso mesmo. Seu Pedro, ex pescador.

Não tem ninguém embarcado não, é tudo avulso. Seu João dos Milagres 
Os pescadores que exercem ou já exerceram a profissão foram solicitados a falar sobre a atividade de pesca, sobre como é a vida de pescador. Eis alguns relatos:

\begin{abstract}
Não é muito boa, o pescador tem família, ele tem que exercer a profissão né (...) muitos entram na pesca mas depois tá arrependido (....) o mar é muito perigoso, é uma atividade muito complicada (...). Seu Joaquim, pescador.

(...) pescador é uma vida sofrida (...) a gente vai e não sabe se a gente volta, porque é uma vida perigosa, a gente não consegue dormir de noite, uma vida muito sofrida, graças a Deus eu saí dessa vida, saí assim porque era pra longe né, agora é só aqui pertinho de casa mesmo (...) pra longe eu não fui mais não, nem tô mais a fím de ir, tenho fé em Deus. Seu Epaminondas, pescador há 33 anos.
\end{abstract}

Não ganha nada, é pouco, sofre muito no mar. Seu Luiz, ex pescador.

Na realidade é uma vida muito sofrida né, pescador é um cabra, uma pessoa que sofre (...). Seu Pedro, ex pescador.

Sofrimento e perigo foram as palavras mais constantes nas respostas do pescadores. Observou-se que a vida de pescador é bem mais castigante do que a das marisqueiras. É habitual que nas comunidades de pescadores ambos os conviventes exerçam profissões afins (o homem, a pesca; a mulher, a mariscagem), razão pela qual a mesma pergunta foi dirigida às marisqueiras ao fito de se conhecer melhor a realidade dessas comunidades:

Eu gosto, né. (...) Rapaz, marisqueira é assim (...) a gente vai pra pesca e a gente pesca o sorôrô, o carangueijo, o camarão... aí a gente traz, se der pra vender a gente vende, se num der a gente fica em casa pra gente se alimentar. Dona Joanita, marisqueira.

(...) tem muitas que gostam, faz mesmo porque acha bom, é divertido (...). Dona Benaia, do lar, ex marisqueira.

A vida não é muito ruim não, não é das melhor, mas também não é ruim não, porque a gente pega o siri de gererê, arranca o búzio com colher, pega o siri com a rede que a gente faz e pega peixe de tarrafa, pega de linha, pesca de linha, não é muito ruim não, não é das melhor, mas também não é das pior não. Dona Marcilene, marisqueira, filha de pescadores.

Percebeu-se que atividade de mariscagem em si, apesar do sol implacável e da incerteza quanto à comercialização da produção, é até certo ponto agradável, pois elas geralmente trabalham em grupo e aproveitam esse momento para colocar as conversas 
em dia. Já para os homens, como disse o Seu Epaminondas, é uma vida muito sofrida e até perigosa quando a pesca é feita mar adentro.

Os pais foram perguntados sobre quais seriam as maiores dificuldades da profissão de pescador ou seus pontos negativos. As mais citadas foram: o perigo de se trabalhar no mar, a baixa lucratividade da atividade, a imprevisibilidade da produção, a escassez do pescado e os problemas de saúde resultantes do exercício da profissão, nessa ordem.

A perda da vida no mar constitui o maior temor entre os entrevistados:

Assim, pode virar o barco, se tiver muito longe (....) tem vez que chove muito né, aí é muito difícil, pode virar, se virar longe no meio do mar como é que voltam pra casa? Não tem como voltar. Dona Marcilene, marisqueira, filha de pescadores.

(...) o mar né, cê sabe como é, só tem mesmo as água e o barco né, e Jesus. (...) que Deus defenda naufragá lá no mar, como já aconteceu, muitos morreram, só tem mesmo Jesus por nós, a gente dentro dum barco, vai que um barco daquele, que Deus o defenda, fura, o pescador né...morrem, uns morrem, os que se salvam é um milagre de Jesus. Eu acho uma vida muito perigosa, muito arriscada. Dona Raimunda, agricultora, mãe de pescador.

(...) meu pai também nunca embarcou, ele pescava aqui fora mesmo né, mas meus irmãos embarca e a gente fica rezando pra que volte. Valdete, marisqueira e filha de pescadores.

(...) tá com um ano que morreu aqui, afundou um barco lá, morreu um marido duma prima minha, tudo daqui de perto, morreu cinco, aí aquilo ali deixa a gente assim mais preocupada, eu acho muito perigoso vida de pescador (...) Dona Rosenete, do lar, esposa de ex pescador.

(...) o pior mesmo da nossa pesca é passar 8, 10 dias lá fora numa canoa, nos nossos barcos que não oferece tanta segurança, porque eu acredito que sendo pra morrer, como tem acontecido, é você viajando de avião, de navio, de carro né, até mesmo dormindo em casa (...) aí na água não tem cabelo, não tem em que se agarre. Seu João dos Milagres.

(...) eu mesmo já peguei vários aqui mesmo que morrem no mar. Seu Roberval, motorista de ambulância, esposo de marisqueira.

As embarcações mais comuns na região são o bote, a canoa - à vela ou não - e as lanchas, segundo conversa informal com a presidente da colônia de pescadores. Os óbitos mais comuns decorrem do mar revolto ou das tempestades que fazem a embarcação virar.

Brandão assinala que o mar exige a pesca coletiva: a saída é perigosa e, de uma hora para outra, a onda cresce e o barco não pode imbicar. 
Às vezes a onda vira o barco, envolve os homens e deixa-os sem sentidos. Quando os tiram por mortos, para fora do mar, metem-nos no sal como as sardinhas, "para lhes apertar os ossos". É um grande remédio, dizem. Ano passado houve um que, depois de estar no sal quarenta e oito horas, ainda tornou a si (BRANDÃO, 2014, p. 93).

A cena trágica nos remete ao personagem Ulisses, na clássica obra "A Odisséia":

"Uma grande onda avançou, agigantando-se acima dele e fez rolar a embarcação. Ele foi obrigado a largar o leme e caiu na água (...). O mastro partiu-se pelo meio, quando a terrível tempestade de ventos furiosos o atingiu. (HOMERO, 1985, p. 65)

Para Diegues (1983), o mar representa o perigo, o inesperado. Uma tempestade pode se avizinhar e a qualquer momento virar a canoa:

\begin{abstract}
A insegurança é que marca a vida do mar em oposição à vida da praia. O mar é o espaço das correntes perigosas, dos ventos que mudam de direção, do peixe que se desloca; e, finalmente, mesmo com o peixe no cesto, o pescador enfrenta a instabilidade do mercado (Diegues, 1983, p. 194).
\end{abstract}

Há, também, um outro tipo de pesca perigosa e largamente praticada na região: a pesca de mergulho com compressor. Apesar de vedada pela legislação ambiental, em função de comprometer a sustentabilidade das espécies e a saúde dos pescadores, é utilizada para captura da lagosta, espécie que ainda traz substanciais dividendos para a região de Acaraú.

Percebe-se que a pesca, apesar de arriscada e de produção incerta, se configura para alguns, principalmente os de baixa escolaridade, a única forma de garantia do sustento próprio e da família:

Trabalhar no mar é muito complicado, é muito arriscado (...) mas a pessoa enfrenta porque é o único recurso que tem né, a pessoa se acostuma aí trabalha né, mas é perigoso. Dona Joanita, marisqueira.

(...) aqui é sem futuro, a gente vai mesmo porque não tem outra coisa pra fazer e quem não sabe ler aí fica difícil, tem que escapar por aqui mesmo. Seu Benedito, pescador há mais de 20 anos.

Segundo Maldonado (1986, p. 30), ao se estudar a especificidade da produção marítima é consenso caracterizar a pesca como uma atividade muito arriscada, não 
apenas em relação à segurança física dos pescadores, mas também em relação aos reveses que eles sofrem no mercado, "decorrentes da exploração e ganância dos intermediários e da perecibilidade do pescado, que exige comercialização rápida".

Os entrevistados foram perguntados acerca de quem lucra mais nessa cadeia produtiva. Disseram que o lucro maior fica ora com o atravessador, ora com o dono do barco:

(...) eu acho que quem ganha mais é o intermediário né, aquela pessoa que pega o peixe, aí passa pra outro (...) o pescador acorda de manhã cedo né, de madrugada, enfrenta o vento, o mar e tudo...aí quando ele chega às vezes já quase meio dia, 10:30, 11:00 horas, depende da maré, depende do vento (...) aí aquela pessoa já tá esperando, se acordou mais tarde né, tomou seu café mais sossegado (...) fica esperando o peixe chegar...aí pega compra o peixe bem baratinho (...) o mínimo que ele pode colocar mesmo e paga pelo peixe e aí ele passa pra outro num preço já bem mais elevado (...) Dona Benaia, do lar, esposa de ex pescador.

Os que lucra mais é o dono da embarcação, porque os pescador ganham pouco, porque se caso, faz de conta se tiver pescando lagosta, se der $1000 \mathrm{~kg}$, um pescador em cada quilo acho que ganha 1 real, e se fosse a 100 reais né, aí o dono da embarcação vai ficar com $90 \%$, e quem pesca, quem vai pescar ganha $1 \%$. Dona Josiane, vendedora de cosméticos, irmã de pescadores.

(...) lagosta tá quase de 100 reais, por exemplo, você paga pra mim sabe a como? A 1 real o quilo, ou 1,50. Aí você vai dizer que se você pagar mais caro você não tem como compensar aquela despesa, mas se eu não peguei nada, tudo bem até que eu concordo, mas se eu trouxer 500 quilos de lagosta, 1000 quilos de lagosta, 2000 quilos de lagosta, é uma injustiça (...). Seu João dos Milagres, pesca desde os 10 anos, aprendeu o ofício com o pai.

Acho que quem lucra mais é o dono (...) a despesa também é dele, do dono né, mas quem lucra mais é o dono, pesca de lagosta, pesca de peixe. $\mathrm{O}$ pescador vai pescar peixe, 10 pescador lá, 1 quilo de peixe eles pagam a 1 real e pouco, e o cara...o dono do barco vende de 12, 15 real, até de 17 ele vende, então a maioria é do dono do barco né, o pescador não ganha nada. Seu Luiz, ex pescador.

Dos relatos extraídos constata-se que o pescador, responsável pelo trabalho árduo, é o que menos ganha e muitas vezes não consegue sequer pagar vale que pegou do armador de pesca (dono do barco):

(...) não ganha nada, é pouco (...) sofre muito no mar e não ganha nada, é mixaria, as vezes pega um vale, muitos vai só com o vale e quando vem nem o vale não paga (...) Seu Luiz, ex pescador.

(...) tem gente que passa mais de mês, quando chega às vezes mal dá pra pagar o vale. Dona Josiane, vendedora de cosméticos, irmã de pescadores. 
Outra questão, concernente à imprevisibilidade da produção, foi enfatizada:

(...) os pescadores mesmo, daqui mesmo, se acha que numa canoinha daquela, canoinha aberta, fechada só a metade e no meio aberta né, se taca no meio do mundo aí pra arriscar a vida, pra sustentar a família, as vezes traz, as vezes não traz né, não é muito fácil não, vida de pescador é muito difícil. Seu José das Dores, pescador.

(...) num tem outra coisa pra fazer, ou você embarca ou fica sem nada, você corre o risco de ganhar alguma coisa ou nada. Valdete, marisqueira e filha de pescadores

(...) se fizer pescaria boa ganha aquele dinheiro, se fizer a pescaria ruim, nem dá pra ele, nem dá pro dono. Dona Raimunda, agricultora, mãe de pescador.

(...) o dono ganha mais que é o dono, isso é se pescar bem né, se der como eu lhe disse com a palavra do matuto, se der 2 ou 3 trono já é prejuízo, aí o dono as vezes encosta até o barco (...). Seu Alonso, agricultor, pai de pescador.

A incerteza quanto à produção se deve, entre outros fatores, à complexidade da própria atividade de pesca, vez que esta é dependente do movimento das marés e das condições climáticas, sem contar a natureza cíclica e móvel dos cardumes que pode levar ao êxito ou não de uma incursão pesqueira.

A despeito dos aspectos negativos da pesca (lucro maior do intermediário e imprevisibilidade da produção) observou-se um ponto bastante positivo na fala de alguns participantes quando estes foram questionados se a pesca poderia assegurar um bom futuro para o filho.

Embora a maior parte das respostas tenha sido "não", alguns vislumbraram possibilidades concretas de bom futuro na pesca -, para si e para o filho -, não como empregados, mas como empreendedores, donos do próprio negócio:

Eu num vejo como não, é desanimador né, a não ser se a gente fosse dono, armador de pesca né, quem sabe...cê vê que tem empresários que eles conseguem se sobressair a outros. Valdete, marisqueira e filha de pescadores

O difícil é porque o pescador se ele tivesse condições ele não ia pescar no barco duma pessoa né, se tivesse condições ele ia fazer um barcozinho pra ele né, uma canoinha pra ir pescar, arrumava duas ou três pessoas pra ajudar ele, mas só que não tem...o pobre não tem vez, o pescador não tem vez, vai trabalhar pros outros né, de alugado, porque se tivesse condições ele não ia trabalhar de alugado pros outros né, ele fazia uma canoinha e ia pescar no que é dele. Seu Alonso, agricultor, pai de pescador. 
Pode, eu conheço gente que possui muita coisa à custa de pesca, assim quem tem barco vai pescar fora né, pega muito peixe pra vender (...) passa de 15 , 20 dias no mar e quando vem traz muito peixe né, aí vende, agora pra quem só coisa pra comer num é não, mas assim dá. Dona Marcilene, marisqueira, filha de pescadores.

Dentre as dificuldades mais citadas, a escassez de pescado é uma questão recorrente no discurso dos entrevistados. Muitos registraram que a quantidade de peixes na região diminuiu consideravelmente, sobretudo de uns quinze anos para cá:

(...) de 2000 pra cá arruinou muito e é arruinando direto, por isso os pais de família tão deixando essa vida de mão, caiu muito a pesca no Ceará. Seu Epaminondas, pescador há 33 anos.

(...) de primeiro era muito bom, mas hoje, pra eles arranjarem peixe mesmo tem que ir muito longe, muito mesmo pra dentro d'água (...) Dona Marcilene, marisqueira, filha de pescadores.

Tá com uns 15 anos...daí pra cá arruinou a atividade da pesca, a produção mais pouca, é muita navegação, aí...tudo hoje em dia...quando vai chegando por essa época aí tudo é mais pouco né (...) diminuiu muito, diminuiu $70 \%$ do pescado. Seu Joaquim, pescador há 36 anos.

(...) primeiro as canoas ia ali (...) saiam como agora a tarde quando fosse pela manhã já chegavam com peixe, hoje passa 4, 5, 6 dias pra poder pegar uns 300,400 quilos de peixe, você vê que já diminuiu (...) primeiro eles pegavam só numa noite (...) hoje passa 4, 5 dias pra poder pegar, é mais dificultoso né, já vão mais longe ainda (...) Dona Leidiane, do lar, esposa de pescador.

Esse fenômeno, segundo os participantes, não se aplica somente aos peixes, mas também aos crustáceos, em especial a lagosta que pelo alto preço de mercado sempre representou uma importante fonte de renda aos pescadores da região.

(...) pesca já deu (...) primeiro o pessoal pegava lagosta aí, era bem facin, hoje pra pegar lagosta vai buscar no mar do Pará. Os pescador vai, passa 40 dias na embarcação pra poder pegar aquela lagosta, antigamente pegava aqui de frente, tudo tá diminuindo (...) Dona Leidiane, do lar, esposa de pescador.

(...) a lagosta acabou-se pra gente, não tem mais, não é mais como era, hoje muitos pais de família tá deixando, a pesca está muito fraca e outra a gente não aguenta mais, tá ficando velho. Seu Epaminondas, pescador há 33 anos.

Entre as supostas razões para a diminuição dos estoques pesqueiros, segundo os participantes, estão os barcos ilegais e a grande quantidade de pessoas - físicas e jurídicas - explorando a atividade. 
36 anos.

(...) antes era mais fácil (...) a exploração era menos, tinha menos pescador, hoje tem mais, e devido que esse meio empresário aumentou muito né, o cara tem dois barcos, tem dois currais, aí ele já é um meio empresário, aí aumentou muito, então muitas vezes a nossa produção artesanal ela fica um pouco lá embaixo, desvalorizada por isso mesmo né, você sabe que o que é de empresa ela sempre tem meio pra que seja mais evoluído no preço e vai pro controle de qualidade né, e o nosso não, era mais assim... Seu João dos Milagres, pesca desde os 10 anos, aprendeu o ofício com o pai.

Para Silva (2008) a pesca artesanal sofreu um processo ora de estagnação, ora de queda. Isso se deve a vários fatores, entre eles a exploração excessiva dos estoques pesqueiros. Maldonado (1993), em sua obra "Mestres \& Mares: Espaço e Indivisão na Pesca Marítima", lembra que em diversas ocasiões na história da pesca, a indústria invadiu, com sua frota e suas práticas, os espaços produtivos e sociais da pesca artesanal.

Fazendo um breve retrospecto do crescimento dos desembarques mundiais das últimas décadas, Melo afirma que:

De modo geral, os desembarques mundiais cresceram exponencialmente até o fim da década de 80; houve um declínio de sua taxa de crescimento até atingir o seu pico de produção em meados de 1990 para, em seguida, apresentar tendência visível de queda. Essa condição sugere que, de modo geral, as capturas marinhas mundiais teriam ultrapassado o seu máximo sustentável e estariam em fase de decadência da atividade. (MELO, 2012, p. 45)

A progressiva demanda mundial por alimentos e matérias-primas impeliu a exploração dos estoques pesqueiros, conduzindo a uma diminuição da população de várias espécies capturadas no ambiente marinho. Tais fatores, portanto, evidenciam a existência de sobrepesca no mundo, conclui o autor.

Pode-se constatar, no discurso de alguns pescadores, que eles próprios enquanto classe -, admitem terem contribuído com a pesca predatória, seja desrespeitando o tamanho mínimo de captura de cada espécie, seja pela utilização de artes de pesca proibidas por lei:

(...) tem deles que não traz uma lagosta, mas você sabe por que? Porque eles pegaram tudinho no ano passado, desde a lagosta grande até àquela 
lagostinha miúda (...) Seu João dos Milagres, pesca desde os 10 anos, aprendeu o ofício com o pai.

(...) essa armadilha que nós fizemos, o povo fez pra lagosta, quando era manzuá era muita fartura, e a gente não pegava miúda, hoje não, hoje não tem mais moral (...) hoje o pai de família não respeita mais né (...). Seu Epaminondas, pescador há 33 anos.

(...) nós tamos passando uma crise ruim mesmo (...) tem dias que a gente vai ali pras Marambaia e não pega 1 quilo de peixe pra comer, porque num existe, a gente saia daqui passava 40 dias no mar do Maranhão, tinha dias que pegava de 200, 300 quilos de cação, era só tirando as abas e soltando n'água, ai eu dizia isso aqui vai fazer falta e fez, num existe mais, num tem mais, devido a armadilha da rede (...). Seu Epaminondas, pescador há 33 anos.

Hoje nós temos uma grande dificuldade é que nós não temos mais o nosso produto respeitado pelo próprio pescador. Seu João dos Milagres, pesca desde os 10 anos, aprendeu o ofício com o pai.

Quanto aos problemas de saúde relatados pelos entrevistados, vão desde o perigo de se adquirir um câncer de pele - em razão da constante exposição ao sol - até uma incapacitação total para o exercício da profissão em decorrência de problemas músculoesqueléticos:

Pra marisqueira arranjar um câncer de pele é bem rapidinho (...) cada dia que passa o sol tá pior (...) cê vai mariscar, se não tem protetor né, às vezes o dinheiro num dá pra comprar e tem que ir. E pros pescador mesmo que vão pro mar é do barco virar né, risco de morte mesmo. Valdete, marisqueira e filha de pescadores

Os mais comuns eu vou tirar por dentro da minha casa mesmo, pelos meus irmãos. A alguns adquiriram problemas na coluna, alguns adquiriram problemas (...) nos tecidos musculares, alguns já adquiriram problemas na vista, alguns já adquiriram problemas na pele. Dona Conceição, professora de ensino fundamental, esposa de ex pescador.

Segundo a Dona Conceição, os irmãos são pessoas novas, de 35, 40 anos, que foram obrigados a abandonar a pesca e hoje sobrevivem de "bicos" por não conseguirem mais exercer a profissão.

Rios, Rego e Pena (2011) estudaram os fatores de risco para as doenças ocupacionais e agravos à saúde dos trabalhadores da pesca (exceto os relacionados à acidentes de trabalho). Afirmam que os fatores de risco podem ser decorrentes do ambiente de trabalho (frio, calor, umidade, ventos, radiação solar, vibrações); do comportamento do próprio pescador (fumo, consumo excessivo de álcool, uso de drogas) e dos fatores sociais, como a jornada de trabalho extenuante, as condições socioeconômicas adversas, o baixo nível de instrução e a posição baixa na ordem de classe social. 
Como principais agravos à saúde desses trabalhadores, descrevem alguns citados pelos entrevistados:

(...) problemas músculo-esqueléticos, lesões de pele, alergias respiratórias, problemas oftalmológicos, respiratórios e urogenitais, doenças sexualmente transmissíveis, entre outros; (RIOS; REGO; PENA, 2011, p. 175)

Os autores ressaltam, ainda, que ao uso abusivo do álcool foi atribuída a chance maior de adoecer, além de aumentar o risco de acidentes.

Por fim, uma questão chamou bastante a atenção e merece registro: o abatimento moral de alguns pescadores, provavelmente em razão do trabalho difícil e exaustivo que desenvolvem e das condições socioeconômicas adversas. Isso pode ser percebido pelo depoimento do Seu Benedito:

Perguntado sobre a valorização da profissão, respondeu:

(...) aqui é sem futuro, a gente vai mesmo porque não tem outra coisa para fazer e quem não sabe ler e escrever aí fica difícil, tem que escapar por aqui mesmo.

Indagado sobre o porquê de o pescador não ser valorizado, afirmou:

(...) não tem valor mesmo aqui, tem dias que a gente vai pega o que comer, tem dia que passa 2, 3 dias pra fazer 5 real, 10 real, aí é melhor ficar dentro de casa limpando cajueiro.

Perguntado sobre quem lucra mais na atividade, esclareceu:

Rapaz, aqui na nossa praia ninguém ganha, nem o dono, nem o atravessador, nem o comprador, ninguém, nem o pescador, aqui não dá pra ninguém não, só mesmo para aguentar, para ir se aguentando devagarzinho.

Interrogado sobre o porquê da pescaria não ser boa atualmente, concluiu:

Não é boa, acabou-se, acho que nem peixe existe mais.

Nas palavras de Seu Benedito são perceptíveis os sentimentos de impotência, desalento e desesperança. Aparentam, também, possível baixa estima e tendência à depressão. Seu José dos Milagres, ao contrário, foi o único entrevistado no qual se notou o encantamento pela profissão. Ao ser indagado sobre a profissão e valorização desta pela sociedade, declarou: 
(...) eu gosto da atividade (...). Com 10 anos eu já ia pescar mais o meu pai (...) eu achava bom demais pescar (...) eu me sinto feliz com isso, e é com muito orgulho de ser pescador.

A classe pescadora ela é uma classe além de muitas vezes ser desclassificada, ela é desvalorizada em tudo. Não valoriza e juntamente com o próprio pescador tem ainda alguém que não sabe o valor que ele tem naquela função, porque eu reconheço o valor que eu tenho (...) você faz a sua função e eu faço a minha, então cada qual, ou preto, ou branco, ou feio, ou pobre, ou rico, cada qual tem a sua função, tem o seu valor, eu sempre digo isso pra eles, por que que eu vou me rebaixar e dizer que eu sou inferior ao comerciante que tem muito dinheiro, um fazendeiro que é rico, um jogador que nem o Neimar e outros mais, né? (...).

(...) a melhor, a coisa melhor que tem é pescar, até essa pescariazinha de sentar no chão lá na praia pra tirar o búzio com uma colher, tirando, raspando assim o chão e tirando o búzio. Você tem uma sensação de que tá no outro mundo, é muito gostoso, imagina quando você joga isca, bota a isca em dois anzolzinho e joga pra lá, que o peixe puxa pra lá, puxa pra cá, rapaz aquilo ali dá um prazer muito grande. E também quando você joga a tarrafa que puxa pra cá, traz, aí bota aqui pra cima, 20, 30, 40, 10, 15 tainhas, bagre, carapeba, aquelas carapebazinha, é muito gostoso (...) Seu João dos Milagres, pesca desde os 10 anos, aprendeu o ofício com o pai.

O relato do Seu João dos Milagres revela que a profissão de pescador pode ser muito mais do que apenas um destino trágico. E é possível que muitos outros "João dos Milagres" também pensem assim, conforme se depreende do relato da Dona Conceição:

\begin{abstract}
Mesmo com esse sofrimento tem muitos deles que gostam de estar no mar, que gostam da profissão que exercem (...) Muitos saem felizes quando vai ser realizado a liberação da pesca da lagosta. Eu vejo assim muitos barcos saindo, soltando foguetes, fogos, todos muito alegres (...) mas na verdade pra mim tem mais parte negativa do que parte positiva. Dona Conceição, professora de ensino fundamental, filha de pescador, irmã de pescadores e esposa de ex pescador.
\end{abstract}

\title{
5.2.3. A visão dos servidores do IFCE
}

A análise e interpretação das falas dos servidores propiciará o levantamento de informações sobre a implantação e oferta do curso, bem como o cenário atual de sua oferta.

O roteiro de entrevista contemplou perguntas relacionadas à implantação do curso, à baixa demanda, ao corpo docente e estrutura física do campus, demandas do setor pesqueiro que poderiam ser atendidas pelo egresso do curso, à relação do Instituto com a comunidade e, por fim, à divulgação do curso. Assim, foram definidas as 
seguintes categorias de análise: Implantação e Oferta do Curso; O Curso de Pesca; O Mercado de Trabalho; Baixa demanda; Divulgação do Curso.

\section{a) Implantação e oferta do curso}

A expansão da oferta da educação profissional se deu com o advento da Lei $n^{\circ}$ 11.195/2005, na qual se dispôs que a mesma se daria mediante a criação de novas unidades de ensino por parte da União e, preferencialmente, em parceria com outros entes federativos, setor produtivo ou organizações não governamentais, responsáveis pela manutenção e gestão dos novos estabelecimentos de ensino. Em 2005, portanto, se materializou a primeira fase do Plano de Expansão da Rede Federal de Educação Profissional e Tecnológica, com a construção de 64 novas unidades de ensino.

Em 2007 se implementou a segunda fase do referido Plano de Expansão, que teve como meta a entrega de 150 novas unidades até 2010 em todas as regiões do país, para oferta de cursos de qualificação, de ensino técnico, superior e de pós-graduação, sintonizados com as necessidades de desenvolvimento local e regional.

Extrai-se da fala do entrevistado que Acaraú foi um dos municípios que concorreram para fazer parte da segunda fase do Plano de expansão empreendido pelo Governo Federal, no eixo marítimo-portuário, em razão de sua estratégica localização e deficiências produtivas locais.

(...) o próprio Ministério veio algumas vezes aqui com seus técnicos visitar a localidade e a gente achou que realmente esse era o local ideal pra construir uma escola marítima portuária. Otávio

Afirma o participante, nos anos de 2006 e 2007 houve várias audiências públicas, que contaram com a participação da sociedade civil como um todo, em especial dos empresários, escolas e secretarias municipais de governo. A comunidade foi visitada em feiras, locais de pesca e de venda de pescado. O maior argumento para a possível construção de uma unidade de ensino federal em Acaraú, diz o entrevistado, foi a questão do apelo produtivo local, em razão de sua vocação para a pesca e, também, por trabalhar a questão da carcinicultura:

A ideia era se trabalhar nos apelos produtivos locais de forma a criar novas oportunidades de emprego, gerar renda, melhorar a qualidade de vida do cidadão, levar o ensino da tecnologia, da ciência, de uma nova proposta de pesquisa. Otávio 
Otávio destaca que foi um trabalho árduo a divulgação da proposta de construção de um ente federal de ensino em Acaraú:

(...) os encontros todos eram em público e abertos, a gente trabalhou diretamente com a comunidade, nas casas, cada casa de pescador (...) fazendo isso as vezes à pé, de carro puxado a animal (...). Foi um trabalho árduo, visitando cada família de pescador, mostrando que o governo federal realmente tinha uma proposta interessante para essa categoria (...) Otávio

Segundo o entrevistado, as condições para a edificação do campus em Acaraú, em termos de contraprestação do Município, foram a entrega do projeto arquitetônico, a doação do terreno e toda uma logística para viabilizar a construção:

Acaraú acho que foi um dos primeiros campus que teve uma proposta, um projeto arquitetônico, que se colocou lá na entrada do campus Fortaleza (...) foi um sucesso. Otávio

A proposta idealizada por Acaraú foi a construção de um prédio moderno e diferenciado, ressalta Otávio:

(...) a proposta era de revolucionar em prédios, um prédio mais holístico, que realmente tivesse um diferencial e uma proposta mais moderna de convivência naquilo que é educação e aproximação das pessoas. Otávio

Destaca o entrevistado, que o projeto proposto sofreu adaptações e modificações por conta de redução orçamentária, fato que não descaracterizou a proposta inicialmente idealizada:

(...) quando veio o orçamento a gente foi começar a cortar (...) mas mesmo assim ficou esse prédio belíssimo que é o campus de Acaraú, um dos mais bonitos do Brasil. Otávio

O IFCE/Acaraú deu início às suas atividades no segundo semestre de 2010 com os cursos de pesca, aquicultura e restaurante e bar, em salas cedidas pelo Poder Público enquanto o prédio se encontrava em construção.

Segundo dados extraídos do Ministério da Educação, no período de 2003 a 2010, o Ministério da Educação entregou à população 214 unidades e entre os anos de 2011 a 214 foram investidos mais de $\mathrm{R} \$ 3,3$ bilhões na expansão da rede.

Indagado sobre as razões de escolha dos cursos técnicos de nível médio em detrimento de outros, o entrevistado informou que a decisão se baseou em um grande 
problema da região, a empregabilidade:

Porque o tecnólogo não tinha uma aceitação, a sociedade tinha dificuldade pra arrumar emprego. Otávio

Questionado sobre eventuais facilidades ou dificuldades nesse processo de implantação o participante informou:

A maior facilidade foi o Governo Federal estar atento, fazendo os cursos, capacitando os gestores que estavam à frente, contratando pessoas, os técnicos, viabilizando os congressos e as visitas (...). Nós tínhamos algum problema com a população de pesca, os filhos de pescadores tinham um grau de analfabetismo muito grande (...) a gente tentou fazer um curso para resgatar, trazer, fazer a inclusão desse pescador para que ele pudesse ter uma escola como essa (...) então o próprio Governo Federal criou produtos dos PROEJAS, técnico do PROEJA.

Indagado sobre eventual curso, à época, para alfabetizar os pescadores, o participante citou o projeto de alfabetização em Macau, desenvolvido pelo IFRN:

(...) a gente tava começando, como experiência, por exemplo, saímos daqui e fomos fazer em Macau (...) uma experiência lá com 100 pescadores nas regiões de pesca e desses 100 não houve nenhuma evasão, todos terminaram (...).

\section{b) O Curso de Pesca}

O curso se dá no regime seriado semestral, com duração de 04 (quatro) períodos letivos. Até 2014.2 o primeiro período era compreendido por disciplinas de educação básica e área geral da pesca, e os 03 (três) restantes referentes às disciplinas de formação técnica, totalizando a carga horária de 1.520 horas.

Atualmente, com a aprovação da nova matriz (válida a partir de 2015.1), na qual foram eliminadas as disciplinas de educação básica, à exceção de educação física, que é optativa, o curso totaliza 1.120 horas, excluindo-se da contagem o Estágio Curricular de 200 horas, não obrigatório.

A mudança implantada objetivou, dentre outras razões, adequar o curso aos moldes do Ensino Profissional Marítimo - EPM, ministrado pela Marinha e, indiretamente, aumentar as possibilidades de emprego daquele que possui Caderneta de Identificação e Registro - CIR - no grupo de pesca. O aluno diplomado, que estagiar embarcado sob a égide da nova matriz, poderá receber a CIR com habilitação de 
Pescador Especializado (PEP), que o habilita a desenvolver a atividade na forma embarcada ${ }^{9}$.

A alteração havida, visou, também, preparar o curso para a modalidade à distância $(\mathrm{EaD})$ e, futuramente, para o médio integrado.

O Curso de Pesca contempla os seguintes componentes curriculares: Ecologia e Educação Ambiental; Saúde, Higiene e Segurança no Trabalho; Introdução à Pesca; Relações Interpessoais, Ética Profissional e Responsabilidade Social; Biologia Aquática e Pesqueira, Educação Física (opcional) - $\mathbf{1}^{\mathbf{0}}$ Semestre; Legislação Marítima e Ambiental e a Prevenção da Poluição no Ambiente Marinho; Beneficiamento do Pescado; Segurança em Operação da Embarcação Pesqueira, Procedimentos de Emergência e a Conscientização da Proteção da embarcação; Tecnologia Pesqueira e Marinharia; Associativismo e Cooperativismo Pesqueiro; Extensão Pesqueira - 2o Semestre; Estatística Aplicada; Arquitetura Naval da Embarcação, sua Carga e Estabilidade; Fundamentos de Economia e Comercialização para o empreendedorismo; Controle de Qualidade do Pescado; Oceanografia Pesqueira e Meteorologia; Sistema de Propulsão, Máquinas e Motores Utilizados a Bordo e sua Manutenção - $3^{\circ}$ Semestre; Navegação, seu Serviço de Quarto e Comunicação Marítima; Manobra e Sinalização Náutica; Sistemas Elétricos e de Refrigeração nas Embarcações Pesqueiras; Segurança e Sobrevivência Pessoal no Meio Aquaviário; Administração e Legislação dos Recursos Pesqueiros; Tópicos Especiais em Segurança: Prevenção e Combate a Incêndio e Conhecimentos Elementares de Primeiros Socorros $-\mathbf{4}^{\circ}$ Semestre.

Os entrevistados foram indagados sobre a forma de estruturação do curso, se atende a uma formação mais técnica e prática ou segue uma perspectiva mais acadêmica. As respostas mais recorrentes foram no sentido de que o curso de pesca possui um viés mais prático:

Acredito que a forma como tá estruturado no campus Acaraú ele é bem prático. Damiana

(...) estamos com uma nova proposta de uma matriz curricular e vejo que isso realmente é uma coisa totalmente prática (...) que venha favorecer no mercado de trabalho. Daniel

\footnotetext{
${ }^{9}$ O IFCE aguarda a procedência do pedido pela Marinha, pois o processo está em análise.
} 
(...) com as mudanças que foram feitas na matriz, o curso está extremamente prático (...) aí sim a gente tira um pouco desse viés acadêmico (...). Sofia

Já para Mário, a estruturação do curso é intermediária. Esclarece que se o foco da formação fosse apenas técnico, o curso estaria formando pescadores, o que não é o caso:

Eu acho que como ele foi pensado, ele é intermediário, porque se eu for pensar na formação técnica, somente prática, eu estaria formando pescadores, que não é o objetivo do nosso curso. Mário

A alteração da matriz foi um dos fatores considerados pelos docentes como essencial por conferir mais destaque à questão da prática. As disciplinas de conteúdo propedêutico, a exemplo de Física, Matemática e Técnicas de Comunicação oral e escrita, foram substituídas por componentes curriculares de natureza técnica. Outro fator a ser considerado é a experiência profissional adquirida dos docentes na iniciativa privada, como se verá mais adiante.

Os entrevistados foram solicitados a falar sobre os pontos positivos e negativos do curso, levando-se em conta o corpo docente e a estrutura física do campus. Abaixo algumas respostas em relação ao corpo docente:

Eu acho que o nosso principal aspecto positivo enquanto curso de pesca é o nosso corpo docente (...) todos os nossos profissionais são capacitados e têm muita experiência de mercado. Sofia

(...) eu acho o corpo docente bem eclético, a gente tem gente que vem da universidade (...) da iniciativa privada, (...) de ONG's (..). Ele atende a demanda do curso. Mário

Professores altamente qualificados e capacitados, independentemente da titulação. Alan

(...) o curso de pesca tem um perfil de professores difícil de encontrar em outras instituições. Getúlio

A equipe hoje de pesca que tem aqui é uma das melhores do Brasil, se não a melhor. Regina

A atuação dos docentes no mercado do trabalho é um fator importante, que pode trazer contribuições positivas na ministração das aulas, sobretudo nos cursos técnicos, pois os docentes têm melhores condições de direcionar o conteúdo teórico para questões práticas que o aluno enfrentará no seu cotidiano profissional. A experiência dos 
professores no mercado de trabalho e, também, no terceiro setor, em entidades não governamentais como citado por Mário, são fatores que não apenas enriquecem o quadro docente, tornando-o mais eclético, como também trazem implicações positivas ao curso.

Ainda em relação ao corpo docente, especificamente quanto à questão da titulação, verificou-se dentre os sete docentes entrevistados dois são doutores, três são mestres e dois possuem graduação. Dos três com título de mestre, dois estão em fase final de doutorado, fato que sugere uma preocupação com a constante atualização e aumento da trajetória formativa.

Uma questão que chamou a atenção, que diz respeito a um fator externo, alheio à Instituição, foi a fala da entrevistada Sofia quanto ao baixo nível educacional dos alunos que entram no Instituto:

\begin{abstract}
Nos últimos anos eu tenho me questionado muito sobre isso (...) então eu tenho pensado e até modificado um pouco a maneira de dar aula, tentando atingir o público, (...) alguns alunos que a gente recebe nos nossos cursos hoje mal sabe ler e escrever, e isso dificulta um aprendizado de coisas mais técnicas (...) eu tenho que voltar muito em conceitos básicos pra poder avançar (...) eles chegam num nível bem inferior do que a gente imagina e eu como professora tento alcançá-los (...) eu não tenho como ensinar português ou ensinar realmente a ler (...). Sofia
\end{abstract}

A questão encontrada pela docente para contornar o problema foi aplicar dois tipos de prova: teórica (às vezes oral) e uma prática:

Hoje a linguagem que eu tenho é totalmente diferente (...). Eles não sabem português, eles não sabem escrever na prova o que precisa ser escrito, (...) hoje eu tenho o dobro de aula prática que eu tinha no começo, justamente por causa disso. Então eu faço dois tipos de prova hoje, uma prova teórica e uma prova prática, para tentar remediar. Sofia

O relato da docente revela a necessidade de o professor, continuamente, reavaliar e refletir sobre a sua prática, entendendo que nem todos aprendem da mesma forma e no mesmo ritmo, por isso é necessário encontrar caminhos que contribuam para um melhor desempenho do aluno.

Em relação à estrutura física, por se tratar de campus novo, de apenas 5 anos, a estrutura física não está combalida, peculiaridade de instituições mais antigas, a exemplo das universidades. Nesse aspecto, os entrevistados destacaram os pontos positivos: 
O nosso campus é um campus novo (...) tem uma estrutura muito boa de sala de aula, de suporte pro professor. Damiana

A gente tem salas de aulas muito boas, a gente tem conseguido fazer visitas técnicas, a gente tem transporte. Aonde o curso está inserido é estratégico, a gente com 10 minutos está numa comunidade pesqueira, com 10 minutos a gente está no porto, vendo qualquer tipo de desembarque. Mário

Em relação aos aspectos negativos, a falta de laboratórios e de alguns equipamentos foram os pontos mais recorrente nas falas dos participantes:

(...) falta laboratório, faltam condições. Clarisse

(...) o que não avançou no mesmo ritmo, por exemplo, a construção e equipagem dos laboratórios, então nós temos técnicos de laboratório hoje que estão atuando em outras áreas porque não há um laboratório para eles atuarem. Regina

(...) a gente precisa de laboratórios (...) pra que esse curso possa acontecer da maneira que ele está sendo pensado e reestruturado, porque da maneira que ele foi reestruturado, não tem como nosso profissional não ser inserido no mercado?. Sofia

Faltam equipamentos básicos em algumas situações. Alan

(...) a gente não tem um laboratório específico de navegação. A gente tem cartas náuticas, mesas, alguns equipamentos que (...) são muito bons pra ensinar os alunos, mas a gente poderia ter uns equipamentos um pouco mais avançados. Mário

Com essa problemática de laboratórios, os próprios alunos já me disseram que o curso chega a ser enfadonho, de tanta teoria e pouca prática. Roberto

Apesar de os participantes afirmarem que o curso possui viés mais prático, observa-se que a falta de laboratórios, um dos aspectos mais importantes dos cursos técnicos, pode influenciar negativamente no processo de ensino aprendizagem e, consequentemente, na formação do aluno, tornando-a deficitária.

Tal raciocínio pode ser corroborado com a fala de Mário, ao afirmar que o corpo docente tem boa formação técnica, mas não consegue atender satisfatoriamente a parte de beneficiamento do pescado ante a ausência de laboratório específico para o curso de pesca:

(...) todo corpo docente tem uma boa formação técnica, mas as vezes ele não consegue fazer, principalmente na parte de beneficiamento de pescado. Os professores aqui sabem como fazer isso, só que não tem nenhum material aqui dentro, nenhum laboratório, nenhum canto pra fazer isso, então a gente fica suprindo essa, essa lacuna fazendo visita técnica. Eu diria isso, que, não 
$100 \%$ não, a gente não contribui para a formação técnica e tem deficiência para formar o profissional. Mário

Sofia lembra que a estrutura física inexoravelmente está atrelada à realização de atividades práticas:

A gente precisa melhorar muito a nossa estrutura física pra poder tornar o nosso curso mais prático possível (...) Sofia

Apesar das deficiências em relação aos laboratórios e alguns equipamentos, Mário destaca que, em comparação a algumas universidades, o Instituto está melhor equipado:

Eu diria que a gente (...) tá melhor que as universidades que eu conheço pro aí. Mário

Além do empenho em transmitir a experiência que adquiriram no mercado de trabalho, percebe-se que a forma encontrada pelos docentes para mitigar as consequências nocivas da falta de laboratórios tem sido a utilização de criatividade e a realização de visitas técnicas:

Basicamente com visita técnica. Eu procuro passar para eles o máximo de experiência que eu tenho, falando muito como é na realidade, (...). Clarisse

O fator humano contorna deficiências de infraestrutura. Alan

Os professores fazem verdadeiras mágicas pra poder conseguir atrair a atenção dos alunos (...) Roberto.

(...) nosso corpo docente é muito experiente, acaba dando um jeitinho aqui outro ali, que não deveria ser. (...) uma instituição pública, de qualidade, deveria oferecer todas as condições. Sofia

A despeito da questão orçamentária não ser objeto deste estudo, ao que parece o Plano de Expansão da Rede Federal de Educação Profissional e Tecnológica empreendido pelo Governo Federal privilegiou a construção das unidades em detrimento dos recursos físicos necessários à sua manutenção e oferta de uma educação de qualidade, fato que pode comprometer sobremaneira a formação do aluno. 
O artigo $7^{\circ}$, inciso IV da Lei $\mathrm{n}^{\circ} 11.892$, de 29 de dezembro de 2008, dispõe que um dos objetivos dos Institutos Federais é o desenvolvimento de atividades de extensão de acordo com os princípios e finalidades da educação profissional e tecnológica, em articulação com o mundo do trabalho e os segmentos sociais, e com ênfase na produção, desenvolvimento e difusão de conhecimentos científicos e tecnológicos.

Os entrevistados foram perguntados se o IFCE realiza serviços de suporte à atividade pesqueira, como cursos de extensão. Foi mencionado por vários entrevistados o curso "Pescador Profissional" - POP, destinado à formação de pescadores profissionais, curso indispensável para o pescador poder embarcar:

O curso técnico tem um curso chamado POP. É um curso de 108 horas voltado pra pescadores profissionais. Mário

Curso POP. É exceção no país e foi iniciado aqui. De inclusão social. Mudança de uma cultura marítima, que aqui não existe. Alan

O entrevistado Mário salienta que o curso aborda questões que os pescadores já conhecem pela própria experiência na atividade:

\begin{abstract}
Nesse curso é visto a questão de meio ambiente, segurança do trabalho, salvatagem, tecnologia pesqueira, que é uma coisa que eles sabem, só que a gente organiza esse conhecimento na cabeça deles. Ele sabe fazer um equipamento, ele sabe ir pro mar, ele sabe pescar, ele sabe tudo. Só que ele não sabe como as coisas são classificadas, entendeu? Ele não tem na cabeça dele organizado que a pesca é dividida em vários grupos, das linhas e dos anzóis, das armadilhas, das redes de malhar, as redes de cerco, das redes de arrasto. Ele começa a entender que o mundo todo já organizou isso aí, ele sabe tudinho, ele só não sabia que existia isso. (...) outras coisas eles aprendem mesmo, a usar um colete salva-vidas, a saber o quanto ele deve consumir de água se ele ficar naufragado, fazer um cálculo da quantidade que ele tem, quanto ele deve consumir pra manter o máximo de qualidade de vida durante o período de naufrágio e pra durar mais tempo, né. Mário
\end{abstract}

O curso está condicionado à formação de turmas de 30 alunos, organizada pela Colônia de Pescadores. Possui demanda e baixo índice de evasão em razão dos benefícios indiretos que o pescador pode auferir: aposentadoria e seguro desemprego (seguro defeso):

(...) a gente tem além dos cursos técnicos esses cursos de extensão que eram ministrados pela Marinha, agora a gente está habilitado a ministrar, então o quê que acontece, o pescador ele por livre espontânea vontade não tem interesse em fazer esse curso de atualização, sendo que agora tão condicionando a atualização dele com o seguro desemprego e aí tá chovendo de gente (...). Júlio 
A demanda do curso (...) é grande, tem um interesse muito grande do lado do pescador porque através desse curso ele consegue ter a Carteira da Marinha (....) isso também vai ajudar ele lá no futuro quando ele precisar se aposentar (...) Damiana

Concluindo o curso com êxito, o pescador recebe a Caderneta de Identificação e Registro - CIR.

O artesanato de sucata marinha foi outro curso de extensão citado:

Nós fazemos cursos nas comunidades, oficinas, tentando criar uma identidade com o artesanato aqui da região e voltado para questão da sucata marinha, do resíduo de pescado, que eu acredito que é um potencial pra gerar renda pra essas famílias de pescadores. Regina

Valendo-se novamente da Lei $\mathrm{n}^{\circ} 11.892$, de 29 de dezembro de 2008, o seu artigo $6^{\circ}$, inciso VIII, prescreve como finalidade dos Institutos Federais realizar e estimular o empreendedorismo, o cooperativismo e o desenvolvimento científico e tecnológico.

Segundo dados divulgados pela Organização das Cooperativas Brasileiras, o Brasil possui mais de 6,8 mil cooperativas, distribuídas em 13 ramos de atividades, sendo a pesca inserida no ramo agropecuário. $\mathrm{O}$ número de associados a cooperativas representa hoje $5,7 \%$ dos brasileiros e $22,8 \%$ se somadas as famílias cooperados (OCB, 2015).

As cooperativas são disciplinadas pela Lei $\mathrm{n}^{\circ} 5.764$ de 16 de dezembro de 1971 e sua definição encontra-se no artigo $4^{\circ}$, caput: "As cooperativas são sociedades de pessoas, com forma e natureza jurídica próprias, de natureza civil, não sujeitas a falência, constituídas para prestar serviços aos associados".

As cooperativas têm duplo objetivo: a promoção do desenvolvimento econômico e o bem-estar social. Caracterizam-se pela participação democrática, independência e autonomia. Outra particularidade reside no fato de que suas decisões são tomadas de forma coletiva e os lucros obtidos são distribuídos de forma justa e igualitária, contribuindo para a geração de renda e inclusão social. Diferenciam-se, portanto, de um empreendimento comercial:

(...) um dos grandes diferenciais do empreendimento cooperativo é a participação econômica dos membros, que está diretamente ligada ao que propõe o cooperativismo: pessoas que se unem com o mesmo propósito, de se fortalecer economicamente para ganhar maior poder de escala e, 
consequentemente, mais espaço no mercado, resultando em maior renda e melhor qualidade de vida para os cooperados, colaboradores e familiares, beneficiando, também, a comunidade. (OCB, 2015, p. 18)

Iniciativas como o projeto de artesanato citado pela entrevistada Regina devem ser incentivadas e são capazes de se tornar muito mais do que uma alternativa para a melhoria da renda familiar. Podem, mediante o estímulo do cooperativismo, ser uma alternativa viável para a eliminação - ou ao menos a diminuição - dos intermediários na comercialização do pescado, contribuindo, assim, para o desenvolvimento social e econômico local, da comunidade na qual os pescadores estão inseridos.

Além do curso POP e o de artesanato, o IFCE também realiza cursos de educação ambiental para o público pescador:

(...) a gente costuma ministrar oficinas e cursos de pequeno porte pra educação ambiental. A gente tem trabalhado com o público pescador nesses cursos, principalmente porque grande parte do impacto ambiental para a região costeira de Acaraú é resíduo de pesca (...). Sofia

A entrevistada foi indagada se existe uma relação estreita do Instituto com as associações. Respondeu afirmando que:

(...) a gente tem começado mesmo a trabalhar com as colônias de pescadores, a gente tá começando a trabalhar com a comunidade porque não é um público fácil de ser trabalhado, então demanda uma relação de confiança de longo prazo pra que resultados comecem a ser obtidos, (...) talvez no começo isso não tenha sido pensado, né. A gente pensou enquanto instituição, instituição pública, que eles nos procurariam e isso não aconteceu, então hoje a gente os procura (...) Sofia

Um aspecto relacionado à extensão, que também se constitui um ponto negativo, não exclusivo do curso de pesca, segundo a entrevistada Regina, é a alta rotatividade dos professores em decorrência do Plano de Expansão, como explica:

Eu acredito que outro aspecto negativo seria, e isso não acontece só com o curso de pesca, o processo de interiorização acabou trazendo profissionais de outros municípios, alguns se mudaram pra cá e estão reconstruindo a vida, estão trabalhando aqui, outros continuam com seus familiares, com seu núcleo familiar noutro município (...) então ele (professor) não consegue se comprometer com ações de extensão, de pesquisa, porque ele está pleiteando a remoção dele para outro campi para ficar perto da família e isso faz com que ele não esteja inteiro. Regina

Prossegue a entrevistada exaltando a importância das ações de extensão na medida em que reforça os laços da instituição com os alunos: 
O ensino fundamental e médio são deficientes. A maioria dos meus alunos não consegue escrever corretamente, alguns não conseguem ler, e com todas essas deficiências não dá pra dizer que o problema seja por conta da sala de aula não estar equipada. Então esse aluno vem com muita dificuldade pra cá e aí se você realmente não tiver um compromisso, se você quer fazer apenas a sua parte, aí fica difícil, porque ele vai acabar evadindo, ele vai acabar se desinteressando, então você tem que ir até onde ele está e tentar fazer o que você puder pra resgatá-lo e aí as ações de extensão são muito importantes pra isso, mas nem todo mundo quer trabalhar com a extensão. Regina

\title{
c) $O$ mercado de trabalho
}

Os participantes foram indagados sobre quais seriam as demandas do setor pesqueiro local e da região que podem ser atendidas por um técnico de nível médio em pesca. Buscou-se, com essa indagação, conhecer o mercado de trabalho que se apresenta na região, suas demandas e a questão da empregabilidade.

Antes de entrar nessa seara, conveniente se faz transcrever a fala do participante Mário, na qual relaciona as competências adquiridas pelo técnico:

\begin{abstract}
O objetivo é dar uma formação abrangente do universo da pesca (...). É você formar pessoas empreendedoras, pessoas que tenham alguma relação com a pesca familiar, (...) que possam melhorar essa relação, dessa cadeia produtiva. Ele sai do curso sabendo que ele pode ganhar mais dinheiro com a pesca se ele melhorar a qualidade do pescado. Ele sai daqui do curso técnico sabendo que se ele melhorar as condições da embarcação ele vai tornar a atividade mais segura. Ele sai aqui do curso sabendo que ele pode melhorar, inclusive, a condição laboral a bordo, melhorando algumas estratégias ergométricas, por exemplo, para ele não carregar tanto peso, se agachar tanto. Ele pode sair daqui do curso sabendo preparar alguns tipos de produto, oriundos da pesca. Ele pode ser um comerciante do pescado e do subproduto desse pescado. Mário
\end{abstract}

É consenso entre os participantes a existência de demandas na região que poderiam ser atendidas por um técnico em pesca. Dentre elas destacam-se: a possibilidade de empreender o próprio negócio, ser empregado nas indústrias de beneficiamento, em diversos setores (gerencial, de produção, controle de qualidade); trabalhar no terceiro setor e em órgãos públicos, mediante concurso público. Eis algumas respostas:

(...) encarregado de linha de produção, trabalhar no controle de qualidade dessa indústria ou até ser gerente (...) Daniel

(...) quando a gente chega pra comprar um peixe em qualquer peixaria (...) você se assusta e não compra porque não tem higiene, eles não sabem como tratar esse peixe, como conservar esse peixe (...) um técnico que sair do campus hoje formado e for montar o seu próprio negócio, com certeza esse 
local vai ser um diferencial e hoje a cidade tem muita gente de fora (...) um povo mais exigente. Damiana

(...) trabalhar em órgãos públicos ou não governamentais, como ONG's, (...) EMATERCI, (...) IBAMA, (....) Secretaria de Meio Ambiente, Secretaria de Pesca. Mário

A secretaria de meio ambiente deveria ter profissional nessa área, porque grande parte dos impactos ambientais que ocorrem em Acaraú são procedentes da pesca, derramamento de óleo, resíduos sólidos, então deveria ter um profissional pra gerir isso. Sofia

(...) a pesca tem grandes oportunidades de trabalho (...) é um segmento que está faltando muita gente qualificada e com experiência (...) Getúlio

Ao que parece a demanda existe, sobretudo nas indústrias de pescado, que possuem em seu quadro um número elevado de funcionários, contudo, a efetiva inserção desses alunos no mercado de trabalho local encontra uma série de óbices de ordem legal, ética, até mesmo cultural. Nesse sentido a fala de Júlio é bastante esclarecedora:

Eu acho que o principal mercado que ele pode ser inserido é exatamente as indústrias de beneficiamento porque essa nunca vai parar, independente da pesca (...) a indústria beneficia tanto o que vem da pesca como o que vem da aquicultura. Júlio

O entrevistado continua sua explanação dizendo que apesar de haver mercado, ele acaba sendo restrito, porque o técnico é preparado para exercer atividades qualificadas, por exemplo, cuidar da qualidade do pescado e não simplesmente para o trabalho mais rudimentar, de manuseio direto com o produto:

(...) acaba sendo um mercado restrito porque quem tá com a mão na massa não precisa ser um técnico, um técnico ele vai tá trabalhando no controle de qualidade, uma atividade mais qualificada, não tacando a mão na massa que é onde tem realmente 300, 400 funcionários dentro da indústria da pesca, é descascando, é filetando, é lacerando, e a gente não acha que seja um perfil pra um técnico, mas é um mercado possível que a longo prazo. Júlio

Outra questão interessante, apontada pelo participante, é que não há legislação que obrigue a presença de um técnico para a manipulação do produto, fato que propiciaria aos egressos maiores oportunidades de inserção no mercado de trabalho:

(...) eu vejo um grande problema é a questão trabalhista, por exemplo, por que a indústria quer essa mão de obra? Porque é uma mão de obra barata, não tem legislação nenhuma que obrigue que quem vai manipular esse pescado tem que ter um curso técnico, se tivesse aí com certeza era um mercado gigante (...) mais uma vez é a mesma questão da pesca, quanto menos qualificado pra mim melhor porque eu pago menos (...). Júlio 
O que se sobressai da fala dos participantes é que para os empresários da indústria de pescado o lucro é mais importante do que a presença de um empregado capacitado em sua empresa. Essa visão imediatista e eminentemente capitalista, baseada na exploração do trabalhador, é bastante recorrente na fala dos entrevistados:

(...) elas tem uma relação com os trabalhadores ainda muito ruim, elas não seguem as leis trabalhistas. Mário

Acredito que o empresário aqui queira ter muito mais lucro, então não vai querer pagar o profissional de qualidade (...) Damiana

(...) o empregador não tá nem aí, infelizmente (...) o empresário da pesca, da indústria, ele não tem esse compromisso todo na realidade com a atividade, a não ser a lucrativa né, assim de investir no seu profissional, adquirir uma mão de obra melhor capacitada, de nível melhor, pra que com isso ele melhore a qualidade do produto dele, infelizmente ele tem aquele pensamento que tá dando certo assim. Clarisse

Extrai-se da fala dos entrevistados uma constatação explícita de desvalorização do profissional qualificado pelo setor empresarial e uma oculta subserviência dos atuais trabalhadores que se submetem a essas relações de trabalho iníquas e abusivas, provavelmente por terem baixa escolaridade, limitadas oportunidades socioeconômicas e pouca consciência de suas possibilidades cidadãs.

Para alguns participantes, a empregabilidade pode ser mais facilmente conquistada fora do mercado de trabalho local e da região:

(...) a maioria dos técnicos de construção naval foram pra fora, eles não ficaram aqui, eles foram pra Fortaleza, eles foram pra Recife, eles foram pro Rio, eles não ficaram aqui em Acaraú, não existe mercado em Acaraú, o mercado ele está se construindo, o que existe são promessas, e o que existe também é o empresariado que quer o pessoal inesclarecido pra ele tacar o chicote e ficar lá 12 horas trabalhando, suando, pra ganhar uma merreca no final do mês, infelizmente existe isso. Lúcio.

Não dá para inserir ainda os alunos, eu creio que os alunos que tem disponibilidade pra sair da região de Acaraú conseguem emprego mais fácil do que os nossos que estão ficando aqui, sendo que o nosso mercado precisa desses alunos atuando. (...) Sofia

Indagou-se à participante Sofia qual seria o motivo da não absorção dos técnicos formados pelo Instituto e ela assim respondeu:

Eu acho que nós temos um mercado tradicional ainda, talvez as pessoas que estejam gerindo esse mercado ainda estão com um pensamento muito retrógrado (...) e não querem avançar. Nós estamos numa cidade pequena, talvez seja isso, um pensamento ainda muito antiquado e não pensam no gerenciamento de uma atividade a longo prazo. Sofia 
Uma hipótese que se levanta, tanto em decorrência desse problema de empregabilidade, quanto da forma superficial como foi narrada por Otávio a criação do IFCE/Acaraú, é que os arranjos produtivos da região não foram construídos.

Apenas para reforçar a hipótese lançada acima, quando indagado o participante Getúlio sobre os cursos de extensão, este afirmou:

(...) o que está faltando é uma ligação maior do setor produtivo com a gente.

\section{Getúlio}

A fala de Getúlio se deu quando este respondia pergunta relacionada às demandas do setor pesqueiro local:

(...) nosso aluno aqui está preparado para suprir qualquer segmento da área da pesca (...) desde que o setor pesqueiro, ou seja, o setor produtivo dê oportunidade para ele estagiar. Getúlio

A opinião de Getúlio é corroborada pela entrevistada Clarisse:

(...) eu acho que falta um pouco ou muito de aproximação entre o Instituto e os empregadores. Clarisse

O contexto apresentado conduz à reflexão sobre a importância dos arranjos produtivos locais (APL's). O artigo $6^{\circ}$, inciso IV da Lei $\mathrm{n}^{\circ} 11.892$, de 29 de dezembro de 2008 dispõe que os Institutos Federais têm por finalidade "orientar sua oferta formativa em benefício da consolidação e fortalecimento dos arranjos produtivos, sociais e culturais locais, identificados com base no mapeamento das potencialidades de desenvolvimento socioeconômico e cultural no âmbito de atuação do Instituto Federal".

O arranjo produtivo local, diferentemente dos demais empreendimentos coletivos, não é determinado por contrato ou tampouco é constituído sob a forma de uma pessoa jurídica. Pode-se definir arranjo produtivo local como:

\footnotetext{
Uma aglomeração de empresas, localizada em um mesmo território, que apresenta especialização produtiva e mantém algum vínculo de articulação, interação, cooperação e aprendizagem entre si e com outros atores locais, tais como: governo, associações empresariais, instituições de crédito, ensino e pesquisa (CASTRO, 2009, p. 8)
}

Ao se falar em APL, Castro (2009) ressalta que a presença de vários atores é fundamental (empreendedores, agentes e instituições). Estes, por meio de suas ações, 
podem contribuir, direta ou indiretamente, para o desenvolvimento da atividade produtiva local:

Um APL não é reconhecido somente pelas ações das empresas ou dos empreendedores, mas também por outras entidades públicas ou privadas comprometidas com o desenvolvimento do APL. São exemplos de atores locais as instituições de promoção, financiamento e crédito, de ensino e pesquisa, os centros tecnológicos, as associações empresariais, os prestadores de serviços, as organizações do terceiro setor e os governos em todos os âmbitos, fisicamente localizados no APL ou próximos. (CASTRO, 2009, p. $11)$.

\section{d) A baixa demanda}

Os entrevistados foram solicitados a opinarem sobre a baixa demanda em relação ao curso de Pesca. Para quase a totalidade dos entrevistados a baixa demanda está relacionada à falta de informação, ou seja, ao entendimento equivocado quanto ao curso, sua proposta e o profissional que se propõe a formar. Abaixo algumas respostas:

(...) todo mundo entende que o curso técnico de pesca é pra formar pessoas para trabalharem diretamente na pesca, ou seja, serem pescadores e isso não atrai a população, sobretudo a população regional que sabe muito bem o que é a pesca. Então como eles conhecem a atividade de pesca, eles não querem ser pescadores. Mário

Muitos não entenderam que o nosso curso não é pra formar pescadores. Nós temos uma visão muito mais de gestão da pesca, de uma gestão sustentável, de modificar esse tipo de atividade na região. (...) eles pensam que a atividade não é lucrativa ou não é importante. Sofia

Quando se fala em pesca, o pessoal associa logo a ir pescar, então isso acaba gerando um receio muito grande em relação a área, eu acho que a baixa procura é devido à falta de informação (...) a informação ainda é entrave (...) no processo de conhecimento do curso (...). Damiana

(...) falta de informação para a população, para a comunidade, do que realmente é o curso técnico de pesca, qual a abrangência. Daniel

Tá faltando informação chegar à sociedade como um todo. Primeiro do IFCE e dentro disso os cursos que têm aqui. Outros cursos parecem mais apetecedores, como construção naval. A ideia de que a pesca não vale é apenas um mito que precisa ser desmistificado. Alan

Muniz (2005) ao analisar a condição dos pescadores artesanais na contemporaneidade e as reapropriações de saberes decorrentes do confronto entre as modalidades de pesca artesanal e industrial, discorre sobre o processo tradicional de 
aprendizagem. Afirma que a vida do pescador artesanal não pode ser desvinculada do processo de aprendizado:

A atividade pesqueira, o conhecimento dos marcos marítimos, das épocas do ano, das melhores condições para captura da espécie, são elementos, dentre outros, aprendidos no cotidiano, fora de uma estrutura formal de ensino. Para a imensa população que habita nos locais como os aqui apresentados, pescar não é algo que se aprende na escola, e sim no convívio com os pais, amigos, vizinhos (MUNIZ, 2005, p. 183-184).

É possível que, por absoluto desconhecimento da proposta do curso de pesca, alguns alunos não encontrem razões suficientes para cursá-lo, especialmente aqueles que já conhecem a atividade.

Para outros entrevistados a baixa demanda também está relacionada ao preconceito em relação à pesca, ao estereótipo que se firmou no imaginário de boa parte da sociedade de que o pescador é um sujeito desclassificado, de segunda categoria.

(...) a gente vê que os pescadores são um povo sofrido, tem essa coisa do pescador ser analfabeto, pescador não tem estudo, não tem instrução, então criou-se essa cultura né que o pescador não pode ser alguém capacitado. Daniel

(...) eu observo que a sociedade tem preconceito com o setor da pesca. A pesca é uma atividade perigosa (...) que não evoluiu no Brasil como os outros segmentos, então a nossa pesca ainda está atrasada em relação a alguns lugares cem anos (...) mas a pesca tem coisa boa e infelizmente a sociedade só vê parte dessa imagem ruim. No íntimo das pessoas é assim: você não serviu pra nada, você não gosta de estudar, então você vai pra pesca. Getúlio

(...) nas pequenas comunidades do litoral ou você é pescador ou se você não dá pro mar você vai ser agricultor, hoje não, com as possibilidades de você estar realizando outras atividades, a pesca realmente tá ficando sempre cada vez mais de lado, e um perfil muito assim interessante, mas triste, que hoje até os drogados estão sendo pescador, os drogados, quem não conseguem emprego, então o próprio dono do barco já bota craque no que a gente chama de rancho, que é comida, antigamente botava cachaça (...) hoje em dia é crack, então até nisso é sempre é uma atividade marginalizada. Júlio

As opiniões acima reforçam a fala dos pais quanto a uma possível desvalorização do pescador pela sociedade.

Outras possíveis explicações estariam ligadas à predileção dos jovens por cursos de nível superior, talvez por desconhecimento sobre as oportunidades que os cursos técnicos podem oferecer:

A sociedade, o pai, a mãe, o avô, a vó, o tio, a tia quer que (...) seu ente querido faça um curso superior. Getúlio 
Não há uma visão com relação ao mercado (...) todos querem fazer um curso superior porque dá status, mesmo que esse curso superior (...) esteja saturado e não tenha onde trabalhar, mas ele tem um diploma superior... ainda se raciocina muito dessa forma, não se consegue enxergar o potencial que a pesca tem aqui pra região. Regina

Aventou-se, ainda, e merece destaque, que a baixa demanda está relacionada ao próprio declínio da atividade, à crise que o setor pesqueiro enfrenta em razão da pesca predatória, da exploração além dos limites suportáveis que a natureza tem de se reproduzir.

Bom, a gente deve levar em conta que a própria profissão de pescador já vem há um certo tempo em declínio (...) essa problemática do declínio da própria pesca, as espécies estão sendo exploradas e não se tem políticas voltadas pra fiscalização. (...) a gente tem conhecimento que o período do defeso, no caso da lagosta, não é respeitado (...) não só a lagosta, o pargo e outros peixes tão sofrendo esse declínio justamente pela pesca predatória. (...) não tem perspectiva, em si, de melhora do setor (...) há um certo descompasso em relação à permanência e até a procura desse público-alvo nosso no caso para continuar o curso (...) a tendência dele é fechar. Roberto

(...) a demanda tá caindo, não só pela saturação de interessado, mas também pelo próprio declínio da atividade. Júlio

A saturação a que se refere Júlio é em relação à repetição da oferta do curso em todos os semestres desde 2010. Uma possível alternativa encontrada pela Instituição para elevar a demanda é ofertar em 2016 o curso de pesca na modalidade à distância:

Para o entrevistado Júlio, a pesca é uma atividade pulverizada e ressalta que Acaraú é mais um polo de desembarque que um polo de pesca:

(...) a pesca é uma atividade muito pulverizada, você não tem polos de pesca, apesar da gente acreditar que Acaraú é um polo de pesca, na verdade ele é um polo de desembarque de pesca. Júlio

O participante explica:

(...) ... ah Acaraú é o maior produtor de lagosta do Brasil .., não é que ele seja o maior produtor porque a lagosta tá sendo pescada lá no Pará, lá no Maranhão, lá no Rio Grande do Norte, mas como os barcos são daqui eles vão pescar nessas áreas e desembarcam aqui porque aqui tem o maior número de empresas de processamento dessa lagosta, então é mais fácil ele desembarcar aqui do que desembarcar lá e trazer de carro né, é uma questão de logística, então aqui não deixa de ser um ponto relevante de pesca, mas é uma atividade que é pulverizada o litoral do Ceará todo. Júlio

O participante encerra dizendo que o curso de pesca à distância - EaD - pode ser uma modalidade que apresente maior demanda:

A gente acredita que na questão do $\mathrm{EaD}$ a gente consiga chamar mais alunos que atuam na atividade, até porque a atividade da pesca hoje em dia é 
complicada, você não trabalha aquelas 8 horas regulares, né, você as vezes passa 2, 3 dias no mar e quando você voltar pode continuar acompanhando o $\mathrm{EaD}$ e se programar para as aulas presenciais. Você está em terra. Júlio

Indagado sobre se o curso presencial seria mais interessante em Camocim, uma cidade que também possui vocação para a pesca, a aproximadamente $120 \mathrm{~km}$ de Acaraú, o participante respondeu:

(...) lá você tem uma pesca mais forte, uma pesca artesanal, aqui a gente não deixa de ser, a nossa também é artesanal, (...) mas é uma quantidade pequena de empresários que detém a maioria das embarcações e lá não, é aquele pescador que tem sua embarcação que vai pescar com um vizinho, um irmão, um primo ou um conhecido, então você tem muitas pequenas embarcações, diferente daqui que a gente tem poucas grandes embarcações, então talvez lá a gente tenha um resultado mais interessante porque a gente tem uma atividade que você vê mais cotidiana no município (...) lá tem peixaria, tem gente consertando barco, construindo barco...é bem mais visível que Acaraú. Júlio

Outro entrevistado também citou a referida cidade como mais apropriada para a oferta do curso:

(...) então é um problema, um carro problema o curso de pesca, inclusive docentes já afirmaram que o curso de pesca é o curso certo no local errado, por exemplo aqui perto nós temos Camocim e lá em Camocim sem dúvida seria um ótimo local para que o IFCE pudesse colocar o curso de pesca. Lúcio

Por fim, novamente veio à tona a questão da baixa remuneração percebida pelos que atuam na atividade da pesca, seja como empregado nas indústrias ou em embarcações de pesca:

(...) talvez o aluno não consiga vislumbrar qual é o ganho profissional que ele vai ter ao término desse curso (...) na pesca, o dono do barco não tem esse interesse, porque ele acha que um curso desse técnico não vai agregar nada ao pescador, pelo contrário, como é uma atividade totalmente desqualificada e braçal, quanto menos qualificado pro dono do barco é melhor porque ele paga um salário menor (...). Júlio

Pelos relatos ora transcritos percebe-se que pesca não é um segmento atrativo para os alunos que concluem o ensino médio. Além de haver uma ideia equivocada e generalizada de que o curso serve apenas para preparar pescadores, a profissão de pescador é alvo de preconceito por parte da sociedade, o que acaba levando o aluno a não optar pelo curso.

\section{e) Divulgação do curso}


Os cursos técnicos de nível médio do IFCE/Acaraú são ofertados semestralmente, por meio de Edital, àqueles que concluíram o ensino médio. Até o semestre 2015.1, a oferta se dava por meio de processo seletivo - prova. Atualmente, para o semestre que se iniciará em 2015.2, com atraso em virtude da greve dos servidores, o critério de seleção será por histórico escolar (maior média nas disciplinas do ensino médio).

Aos entrevistados perguntou-se como se dá a divulgação dos cursos ofertados pelo IFCE. Eis algumas respostas:

\begin{abstract}
A divulgação é feita por edital geral que é aberto pra todo o Estado, pros cursos técnicos, uma chamada única e localmente a divulgação é rádio, é internet, as redes sociais, facebook e algumas visitações nas escolas. Júlio

(...) nós temos um setor pra isso, pra divulgar o curso levando às escolas, e rádio, nós estamos no interior, a maior parte da comunicação é rádio, panfleto ou até as redes sociais (...) Sofia

Existe um setor da própria instituição que é responsável pela divulgação (...). Getúlio
\end{abstract}

A divulgação é direcionada mesmo ao aluno, comunidades, mas ainda na comunidade é muito pouca, mais é nas escolas onde fazem o ensino médio. Damiana

A Coordenação de Comunicação e Eventos é a responsável pela divulgação do curso, a qual se dá por vários meios de comunicação: panfletos, rádio, site do IFCE, redes sociais e visitação nas escolas.

Vários participantes afirmaram que, dentre os veículos de comunicação disponíveis, o boca a boca é o mais eficaz:

Os nossos alunos (...) divulgam bastante. No primeiro dia de aula eu costumo perguntar como é que você soube do curso, o que lhe levou a estar aqui, então grande parte...ah é o aluno que tá no $4^{\circ}$ semestre, ele tá fazendo tanta coisa legal, ele tá embarcando, sabe construir um manzuá (...). Sofia

Hoje, principalmente, se nós formos conversar com os nossos alunos que estão chegando no primeiro semestre, a maior parte deles veio por conta do contato com um amigo que já é aluno do IFCE, então acaba que um aluno vai chamando o outro. Regina

(...) temos uma série de outros meios e veículos e o principal é o boca a boca. Lúcio 
A fala dos participantes, em relação à eficácia do boca a boca, corrobora com os dados apurados na parte quantitativa (questionário aplicado aos alunos do $3^{\circ}$ ano do ensino médio) onde se registrou que $45,7 \%$ dos que conhecem o curso de pesca foi por intermédio de amigos ou parentes que estudam no Instituto.

Alguns participantes entendem que o curso é conhecido e divulgado:

As pessoas, em maior ou em menor percentual, elas conhecem já o curso (...).

\section{Getúlio}

(...) o curso é divulgado. As pessoas sempre sabem dos processos de seleção.

\section{Mário}

A opinião de alguns entrevistados contrasta com os dados levantados por meio do questionário aplicado aos alunos do ensino médio, pois se apurou que 64,4\% deles, nas quatro escolas pesquisadas, não conhecem o curso, muito embora já tenham ouvido falar dele e apenas 19,0\% dos alunos afirmaram conhecê-lo razoavelmente. Os números indicam que a divulgação empreendida pelo Instituição é deficitária e precisa ser aprimorada.

A fala de um participante, Lúcio, chamou a atenção. Ele entende que a baixa demanda é uma questão muito mais abrangente, que perpassa não apenas o preconceito com o curso de pesca mas até o lançamento dos editais de seleção sem antecedência mínima:

(...) o problema de você lotar turma de pesca é um problema muito mais abrangente (...) os editais são lançados muito em cima da hora de começar as inscrições, o que muitas vezes invalida o planejamento (...). Na verdade são vários fatores que acabam colaborando, desde a questão do preconceito em relação ao curso, desde a questão da organização da Instituição. Lúcio

O entrevistado ressalta que algumas divulgações são acompanhadas por professores, no entanto, devido à correria do cotidiano acadêmico, elas não são frequentes:

(...) algumas divulgações são acompanhadas por professores que acabam sensibilizando os alunos acerca dos objetivos do curso, só que como a gente sabe da correria que é o cotidiano acadêmico, se torna esporádico (...). Lúcio

Acrescenta, o participante, ser comum nessas visitas às escolas o interesse por outros cursos: 
(...) o que acontece é que muitas vezes ao final das nossas explanações acontece aquele famoso "e quando vai ter outros cursos?" (...) uma ansiedade de novos cursos é muito grande (...) o nosso campus ele está aos poucos investindo na implantação de novos cursos. Lúcio

Observa-se dos relatos colhidos que a divulgação é realizada pela Coordenação de Comunicação e Eventos geralmente logo após o lançamento dos editais - impedindo salutar planejamento e, ocasionalmente, por alguns professores, de forma individual ou na companhia do representante da referida coordenação. 


\section{PRODUTO TÉCNICO}

Os resultados obtidos com a coleta de dados apontaram para a necessidade de mobilização do Instituto em melhorar a divulgação do curso. Para tanto, importante se faz aumentar a frequência de visitas às escolas a fim de conferir-lhe maior visibilidade. Outra questão que merece registro, bastante recorrente na fala dos servidores entrevistados, é o entendimento generalizado e equivocado de que o curso se destina a formar pescadores. Assim, com o intento de desconstruir esse mito, apresenta-se como produto técnico uma metodologia própria de divulgação do curso, que tem como objetivo precípuo informar os destinatários sobre a sua real proposta e o tipo de profissional que este se propõe a formar: um gestor da pesca e não um pescador.

A partir do diagnóstico supracitado, surgiu a necessidade de estruturação de um roteiro de visita e divulgação, cujo objetivo basilar é fornecer informações reais e fundamentadas sobre o curso, bem como motivar e despertar o interesse dos alunos pelo mesmo. A ideia é utilizar como estratégia metodológica uma abordagem participativa, de forma que os alunos possam interagir com a equipe de divulgação e com os conteúdos do curso.

O referido instrumento foi idealizado levando-se em conta as características do público-alvo - os alunos do ensino médio -, razão pela qual foi adotada uma linguagem simples e de fácil compreensão, despida dos termos técnicos próprios de um curso técnico, sabidamente pouco didáticos.

É importante ressaltar neste momento a necessidade da aproximação da equipe pedagógica do Campus com os docentes e gestores do curso, tanto para fins de planejamento, como execução e avaliação destes momentos de divulgação. Isto porque é sabido que, em sua maioria, os docentes que atuam no curso vivenciaram uma formação técnica e tiveram pouco ou nenhum contato com o conhecimento e reflexões pedagógicos, o que muitas vezes dificulta a transposição didática dos conteúdos específicos da área e, consequentemente, inviabiliza o processo de sensibilização e motivação dos alunos.

O documento também apresenta o Manual Descritivo do Curso, que consiste nas competências que o aluno irá desenvolver ao longo do curso, ou seja, em breve síntese, 
o que ele irá aprender. Foram escolhidos pontos de cada disciplina que eventualmente possam despertar a curiosidade e o interesse do aluno.

A proposta é de que as visitas sejam semestrais, iniciando-se com as turmas do primeiro ano do ensino médio, nas escolas Tomaz Pompeu de Souza Brasil, Liceu de Acaraú Maria Alice Gomes, Maria da Conceição de Araújo (Aranaú) e Vicente de Paulo da Costa (Juritianha). Indispensável se faz o contato permanente com a Coordenação da CREDE 3 e a atualização periódica dos telefones e e-mails dos diretores de cada escola e de seus representantes ou auxiliares, a fim de que as visitas sejam previamente agendadas.

A seguir, encontram-se a metodologia de divulgação e o manual descritivo do curso, material complementar que será distribuído e explicado aos alunos nas visitações.

\subsection{METODOLOGIA DE DIVULGAÇÃO DO CURSO DE PESCA}

\section{Dados Gerais sobre a Oferta}

\begin{tabular}{|l|l|}
\hline Identificação & Técnico Subsequente de Nível Médio em Pesca \\
\hline Nível & Médio Subsequente \\
\hline Certificação & Técnico de Nível Médio em Pesca \\
\hline Modalidade & Presencial \\
\hline Duração do curso & 4 semestres \\
\hline Requisito de ingresso & Ensino Médio Completo \\
\hline Forma de ingresso & Análise de histórico escolar \\
\hline Número de vagas (anual) & 35 \\
\hline
\end{tabular}

\begin{tabular}{|c|c|}
\hline ATIVIDADE & OBJETIVOS \\
\hline $\begin{array}{l}\text { Introdução } \\
\text { 1. Iniciar as atividades indagando aos alunos se } \\
\text { estes possuem familiares ou conhecidos que } \\
\text { trabalhem com pesca. Em seguida, questioná-los } \\
\text { sobre o que pensamlacham da profissão } \\
\text { (Exemplo: É segura? É rentável? ) }\end{array}$ & $\begin{array}{l}\text { - Fazer uma sondagem do contato que os alunos } \\
\text { já possuem com a atividade pesqueira, seus } \\
\text { conhecimentos prévios e impressões sobre a } \\
\text { profissão. }\end{array}$ \\
\hline $\begin{array}{l}\text { Desenvolvimento } \\
\text { 1. Uma breve fala sobre a importância da } \\
\text { atividade pesqueira, tanto de forma geral, como } \\
\text { os seus impactos na região. } \\
\text { 2. Apresentação do curso: de forma dinâmica e } \\
\text { ilustrativa, expor a natureza do curso, seus } \\
\text { objetivos, bem como o perfil de formação e } \\
\text { possibilidades de atuação profissional. }\end{array}$ & $\begin{array}{l}\text { - Contextualizar e justificar a relevância do curso } \\
\text { Técnico em Pesca para o desenvolvimento } \\
\text { nacional e regional. } \\
\text { - Oferecer informações reais e fundamentadas } \\
\text { sobre o curso. } \\
\text { - Distribuir o manual descritivo do curso }\end{array}$ \\
\hline
\end{tabular}


3. Atividade prática: esta atividade deve ser realizada por um docente ou técnico do curso. Seria interessante aqui, uma demonstração prática, na qual um ou alguns alunos pudessem participar, de forma voluntária. Poderia ser uma demonstração de como usar algum instrumento ou equipamento do curso, como GPS, rádio (VHF e HF), sinalizadores (salvatagem), balsas salvavidas, sempre relacionando essas atividades com as competências que ele irá adquirir no curso. Podem ser utilizadas, por exemplo, maquetes de embarcações para dar noções de arquitetura naval e explicar os conceitos de estabilidade e flutuabilidade.
- Despertar a curiosidade e o interesse dos alunos pelo curso.

\section{Encerramento}

1. Pedir a alguns alunos que se voluntarie a relatar algum aprendizado conquistado a partir da visita. Convidá-los a conhecer o campus e os laboratórios do curso de pesca.
- Avaliar o impacto da atividade realizada.

- Fomentar a aproximação dos alunos do Ensino Médio com o campus, principalmente, com o curso de Pesca.

\section{MANUAL DESCRITIVO DO CURSO}

\section{a) Ecologia e Educação Ambiental}

Entender como os animais, plantas e outros seres vivos interagem no meio ambiente

Diagnosticar os problemas ambientais e encontrar soluções para melhorar a sua comunidade, vivendo num ambiente mais saudável

\section{b) Saúde, Higiene e Segurança no Trabalho}

Aprender a trabalhar nas embarcações e nas indústrias de forma correta e mais segura

Conhecer os equipamentos de proteção de trabalho que previnem acidentes (luvas de aço para manusear facas, de borracha para mexer com anzóis, por exemplo)

Prevenir e combater incêndios (uso de extintores, por exemplo) e como dar os primeiros socorros (ressuscitação em casos de ataques cardíacos e afogamentos - RCP, por exemplo)

Aprender a cuidar melhor de sua saúde 


\section{c) Introdução à Pesca}

Conhecer sobre a pesca, seus tipos, o que vem acontecendo com ela durante os anos - no Brasil e no mundo - e porque ela é importante para a sociedade

\section{d) Relações Interpessoais, Ética Profissional e Responsabilidade Social}

Conhecer os direitos e deveres do pescador

Saber da importância de se relacionar bem no ambiente de trabalho, seja a bordo de um navio ou numa empresa

Aprender sobre ética e como trabalhar em equipe

Conhecer os perigos do uso de bebidas alcoólicas e drogas iícitas a bordo

\section{e) Biologia Aquática e Pesqueira}

Conhecer melhor os seres que habitam nos ambientes de praia, mangue e rio (como se alimentam, se reproduzem e se desenvolvem): caranguejo, ostra, polvo, lula, camarão, peixes, tartarugas, algas, corais, estrelas-do-mar, entre outros.

Aprender técnicas de coleta em campo e posterior análise em laboratório.

Aprender a dissecar os animais maiores.

\section{f) Legislação Marítima e Ambiental e a Prevenção da Poluição no}

\section{Ambiente Marinho}

Conhecer as leis que regulam as relações entre as embarcações e o meio ambiente

Conhecer os tipos de poluição, os agentes poluidores mais comuns e os órgãos responsáveis pela política ambiental.

Saber sobre as responsabilidades da tripulação e demais pessoas a bordo para proteger o ambiente marinho.

\section{g) Beneficiamento do pescado}

Conhecer os tipos de pescado e as principais espécies comercializadas

Beneficiar o pescado (peixe, polvo, camarão e lagosta) e conhecer seus coprodutos (embutidos, farinha, óleo) e possibilidades de valor agregado (espetinho de camarão, camarão empanado, por exemplo).

Aplicar os métodos de conservação do pescado: salga, defumação, enlatamento, congelamento e refrigeração. 
Tratar, classificar e embalar o pescado (o camarão tem 9 tamanhos diferentes de classificação, por exemplo)

\section{h) Segurança em Operação da Embarcação Pesqueira, Procedimentos} de Emergência e a Conscientização da Proteção da Embarcação

Trabalhar em segurança, saber o que fazer numa emergência e avaliar a proteção do navio

Adotar medidas nos casos de abandono, furos, encalhe, colisão e explosão da embarcação

Conhecer os procedimentos de salvamento de pessoas ao mar

\section{i) Tecnologia Pesqueira e Marinharia}

Conhecer o funcionamento dos materiais utilizados nas artes de pesca (materiais, instrumentos ou aparelhos usados para pescar, a exemplo dos anzóis, linhas, armadilhas, redes, entre outros)

Identificar os métodos de captura dos recursos pesqueiros

Confeccionar e reparar as artes de pesca

\section{j) Associativismo e Cooperativismo Pesqueiro}

Identificar as formas e a importância do associativismo (associação, sindicatos, cooperativas, fundações)

Mobilizar uma comunidade para organizar uma cooperativa

Conhecer a economia solidária (forma diferente de produzir, vender, comprar ou trocar, sem explorar ninguém e respeitando o meio ambiente).

\section{k) Extensão Pesqueira}

Conhecer as principais políticas públicas para o desenvolvimento da pesca e da aquicultura e as alternativas de desenvolvimento local das comunidades pesqueiras.

\section{l) Estatística Aplicada}

Avaliar numericamente os fenômenos naturais e pesqueiros.

Conhecer as relações de causa e efeito dos fatores naturais. Ex: será que a relação de determinada espécie com os períodos de chuva pode influenciar a produtividade? 


\section{m) Arquitetura Naval da Embarcação, sua carga e Estabilidade}

Identificar os tipos e partes de diversas embarcações e como operá-las de forma adequada e segura

Compreender os conceitos de estabilidade e flutuabilidade e sua importância na segurança da navegação

\section{n) Fundamentos de Economia e Comercialização para o empreendedorismo}

Conhecer como funciona o mercado da pesca, segundo os conceitos de demanda, oferta, produção, consumo e custos.

Saber com tornar-se um empreendedor na área da pesca e o passo-a-passo para abrir o próprio negócio

\section{o) Controle de Qualidade do Pescado}

Receber, transportar, manusear e acondicionar o pescado, evitando contaminações

Conhecer as técnicas de higienização do ambiente em que se manipula o pescado

Identificar as fases de decomposição do pescado

Conhecer as exigências do mercado externo (Japão, Europa e USA) que consomem o pescado brasileiro e os critérios de exportação

\section{p) Oceanografia Pesqueira e Meteorologia}

Descobrir as origens da terra, sua atmosfera e seus oceanos

Saber porque a terra se movimenta e o que há no fundo dos mares

Conhecer a vida no ambiente marinho, as correntes marítimas, a origem e os tipos de ondas e como a maré pode influenciar a vida humana

Compreender o que é aquecimento global, o fenômeno do El Ninho e as previsões do tempo 
q) Sistemas de Propulsão, Máquinas e Motores utilizados à bordo e sua manutenção

Compreender o funcionamento básico de motores, máquinas de convés e motores geradores e sua manutenção.

\section{r) Navegação, seu Serviço de Quarto e Comunicação Marítima}

Conhecer a legislação que trata do tráfego aquaviário nacional e internacional

Entender os processos de comunicação marítima

Conhecer os limites do mar brasileiro, as tábuas das marés, o que são as cartas náuticas, as coordenadas geográficas, saber a sua posição no mar e planejar e executar a sua derrota.

\section{s) Manobra e Sinalização Náutica}

Entender os sinais luminosos, cegos e sonoros, para manobrar e conduzir com segurança a embarcação, bem como as regras de manobras para evitar abalroamentos.

Como atracar, desatracar e amarrar uma embarcação

Identificar os tipos de amarras, âncoras e hélices e tipos de fundo.

t) Sistemas Elétricos e de Refrigeração nas Embarcações Pesqueiras

Conhecer e utilizar os tipos de sistema de refrigeração (motores, câmaras frigoríficas e ar-condicionado)

Utilizar técnicas básicas de reparos e manutenções dos sistemas frigoríficos e de refrigeração

Identificar as temperaturas necessárias para conservação do pescado

Conhecer conceitos básicos de eletricidade, técnicas de reparos e manutenções dos principais componentes dos sistemas frigoríficos e de refrigeração nas unidades pesqueiras

\section{u) Segurança e Sobrevivência Pessoal no Meio Aquaviário}

Conhecer os perigos que ameaçam a sobrevivência e as técnicas de resgate nos casos de abandono da embarcação ou naufrágios

Utilizar os recursos de salvamento e conhecer as práticas com equipamentos salva-vidas

Executar os métodos de comunicação de emergência 
Dominar o pânico em situações de perigo e estresse (instabilidade mental e emocional)

Sobreviver em águas infestadas de tubarões e ser localizado

\section{v) Administração e Legislação dos Recursos Pesqueiros}

Identificar os principais problemas da pesca

Conhecer todos os fatores que interferem na atividade pesqueira: fatores ambientais (marés, fases do ano, el ninho, fases lunares); econômicos (alta produtividade, baixo preço; baixa produtividade, alto preço); e sociais (classes sociais e etárias, escolarização)

Conhecer órgãos que cuidam da gestão da pesca (IBAMA, ICMBio, MMA) e as principais medidas de controle de explotação dos recursos pesqueiros (controle por tamanho de captura, por aparelho de pesca, por cota, por período e por área de pesca).

w) Tópicos Especiais em Segurança: Prevenção e Combate a Incêndio e Conhecimentos Elementares de Primeiros Socorros.

Prevenir e combater incêndio

Reconhecer as urgências e emergências no atendimento pré-hospitalar, identificando o atendimento mais adequado nas situações de riscos

Dominar noções básicas sobre os conceitos das classes de incêndio, agentes extintores, métodos de transmissão de calor e das formas de combate ao fogo

Tratar de ferimentos, envenenamentos, picadas de insetos e cobras 


\section{CONSIDERAÇÕES FINAIS}

Os dados extraídos da análise dos questionários aplicados aos alunos do $3^{\circ}$ ano do ensino médio das escolas públicas de Acaraú e seus Distritos apontaram a preferência destes por cursos em nível de graduação, evidenciando uma predileção pelos cursos de nível superior, principalmente bacharelado, em detrimento dos cursos técnicos.

Restou evidenciado que, de um modo geral, o campus do IFCE/Acaraú é conhecido pelos concluintes do ensino médio, contudo dos que declararam não conhecêlo a maior parte situa-se na zona rural.

Evidenciou-se, ainda, alta rejeição ao curso de pesca, sendo que a maioria dos participantes afirmou que não o conhecem, mas já ouviram falar.

Em relação à divulgação do curso, o meio que se mostrou mais eficaz entre os alunos foi o "boca-a-boca", materializado através de amigos ou parentes que estudam no Instituto.

Por fim, a maioria dos alunos declarou que os pais incentivariam o ingresso deles no curso de pesca, caso decidissem cursá-lo.

A análise das entrevistas revelou que, no âmbito da educação profissional, uma das políticas públicas mais relevantes na área da pesca foi a assinatura, em 2006, do acordo de cooperação técnica entre o MEC/SETEC e a Secretaria Especial de Aquicultura e Pesca da Presidência da República, que viabilizou o aumento de cursos técnicos na Rede Federal e criou os Núcleos de Pesquisa Aplicada à Pesca e Aquicultura - NUPA's.

Em relação aos pais se constatou que a maior parte das pessoas analfabetas entrevistadas são pescadores, marisqueiras e ex-pescadores. $\mathrm{Na}$ percepção dos entrevistados, a profissão de pescador não é valorizada pela sociedade em razão de ser pouco rentável, não oferecer melhoria das condições de vida, não propiciar acesso a determinados benefícios sociais básicos e por não haver políticas públicas para essa categoria. Para maior parte deles, a postura inadequada do pescador em sociedade, resultante, sobretudo, do uso habitual de drogas e envolvimento com a prostituição, também contribui para a desvalorização da profissão. 
Como principais dificuldades da profissão de pescador foram listados o perigo de se trabalhar no mar, a baixa lucratividade da atividade, a imprevisibilidade da produção, a escassez do pescado e os problemas de saúde resultantes desse ofício.

A análise revelou, ainda, que no entendimento dos pais a pesca é uma atividade sofrida, perigosa e pouco rentável. Por essas razões e, ainda, por não vislumbrarem perspectivas de futuro na área da pesca, a maior parte deles afirmou não incentivar os filhos a ingressarem no curso.

Na concepção dos docentes e técnicos administrativos do campus, a forma de estruturação do curso de pesca atende uma formação mais prática do que acadêmica. Destacaram a falta de laboratórios e de alguns equipamentos básicos com os principais pontos negativos do curso e, como positivos, a titulação elevada da maior parte dos docentes, a larga experiência destes no mercado de trabalho, o campus novo, a biblioteca, as boas salas de aula e os bons equipamentos de suporte aos professores.

Quanto aos cursos de extensão, evidenciou-se que dois são habitualmente ofertados quando há demanda: o de artesanato com resíduo do pescado e o curso POP, pescador profissional, que habilita o pescador a trabalhar de forma embarcada.

Em relação ao mercado de trabalho, ficou evidenciado entre os entrevistados que apesar do amplo leque de possibilidades de inserção do técnico em pesca no mercado de trabalho, as oportunidades em Acaraú são reduzidas, sendo a mais concreta e imediata o trabalho nas indústrias de beneficiamento de pescado, que preferem contratar empregados sem qualificação para explorá-los e pagar-lhes baixas remunerações.

Para quase a totalidade dos entrevistados a baixa demanda está relacionada à falta de informação sobre o curso, ou seja, há um entendimento generalizado e equivocado sobre a sua proposta e o tipo de profissional que este se propõe a formar.

Quanto à divulgação do curso, a maior parte dos servidores entende que o curso é divulgado, fato que contrasta com a análise dos dados do questionário, os quais revelam uma divulgação deficitária.

Os fatores que ensejam a baixa demanda são múltiplos, complexos e de difícil solução. Perpassam desde a saturação do curso e a ideia equivocada em relação à sua proposta, quanto o não reconhecimento social e a marginalização do pescador, o 
declínio da atividade em razão da sobrepesca, o perigo e a baixa remuneração que ela proporciona, e a predileção dos concluintes do ensino médio por cursos em nível de graduação.

Muitos desses fatores não são exclusivos da região de Acaraú, mas um problema de amplitude mundial. A despeito desse fato, ações locais e pontuais talvez possam contribuir com a elevação da demanda, como uma divulgação mais eficaz do curso, tal como proposto no produto técnico apresentado.

Por mais habilidoso que seja o servidor da Coordenação de Comunicação e Eventos, a divulgação do curso não seria tão eficaz sem a permanente participação dos professores nas visitações às escolas. Eles, enquanto detentores do conhecimento técnico, são as pessoas mais indicadas e capazes para abordar todas as questões inerentes ao curso ou a algum componente curricular específico.

Ademais, tanto em decorrência do problema de empregabilidade da região, quanto da forma superficial como foi narrada a criação do campus e a implantação do curso, evidencia-se que os arranjos produtivos locais não foram construídos. Assim, necessário se faz uma interlocução maior entre o Instituto e os empreendimentos privados vinculados à pesca, os órgãos de governo em todos os níveis e a comunidade.

A equipe multidisciplinar do Instituto, composta por pedagogos, assistentes sociais, enfermeiras e psicólogos, na companhia dos docentes, podem contribuir com essa aproximação, especialmente junto à comunidade de pescadores e marisqueiras, implementando ações de extensão destinadas a elevação da autoestima dessa categoria, estimulando-os a se alfabetizarem; às boas práticas de saúde e higiene; aos direitos básicos do cidadão e dos pescadores e, principalmente, incentivando o empreendedorismo e formas de associativismo. 


\section{REFERÊNCIAS}

ALLMARE ALIMENTOS. Disponível em: <http://www.allmarealimentos.com.br/pt/> Acesso em 28 de Março de 2015.

ARAÚJO, Nicodemos de. Cronologia da Cidade de Aracaú: 1700 - 1991. Fortaleza: Gráfica Stylus, 1991

1971.

Município de Acaraú: notas para sua história. Fortaleza: Imprensa Oficial do Ceará,

ARAÚJO, Rogério César Pereira de; FREITAS Kelly Silva de; ALBUQUERQUE, Robério Lopes de. Impactos socioeconômicos do Complexo Industrial e Portuário do Pecém (CIPP) sobre os pescadores artesanais, São Gonçalo do Amarante-CE. In: CONGRESSO DA SOCIEDADE BRASILEIRA DE ECONOMIA, ADMINISTRAÇÃO E SOCIOLOGIA RURAL, 47, 2009, Porto Alegre.

ARAÚJO, Silvia Cordeiro de. Pescando Letras: diálogos interdisciplinares entre a educação ambiental e a alfabetização de jovens e adultos no contexto da pesca artesanal. 2008. Dissertação de Mestrado. Centro de Desenvolvimento Sustentável. Universidade de Brasília. Brasília, 2011.

BARDIN, L. Análise de conteúdo. Lisboa: Edições 70, 1977.

BENINCÁ, Ciomara Ribeiro Silva; GOMES, William B. Relatos de mães sobre transformações familiares em três gerações. Estudos de Psicologia, v. 3, n. 2, p. 177-205, 1998. Disponível em: < http://goo.gl/PnRoYW >. Acesso em: 03 fevereiro de 2015.

BERKES, F. Sacred Ecology: tradicional ecological knowledge and resource management. Oxon, UK: Taylor \& Francis, 1999.

BORNHOLDT, Ellen \& WAGNER, Adriana. A gravidez à luz da perspectiva paterna: aspectos relativos à transgeracionalidade. In: WAGNER, Adriana (org). Como se perpetua a família? A transmissão dos modelos familiares. Porto Alegre: EDIPUCRS, 2005.

BOVY, Lambert. O pescador do litoral: um desconhecido? São Paulo: Imprensa Oficial do Estado, 1972. (Coleção Ciências Humanas)

BRANDÃO, Raul. Os pescadores. Lisboa: Porto Editora, 2014. (Coleção Clássicos do Porto)

BRASIL. Constituição (1988). Constituição da República Federativa do Brasil. Brasília, DF: Senado Federal: Centro Gráfico, 1988.

BRASIL. DECRETO No 3.048 - DE 6 DE MAIO DE 1999. Aprova o Regulamento da Previdência Social, e dá outras providências. Disponível em: 〈http://goo.gl/plL6oS〉. Acesso em: 25 Março de 2014.

BRASIL. DECRETO N ${ }^{\circ}$ 6.981, DE 13 DE OUTUBRO DE 2009. Regulamenta o art. 27, § $\mathbf{6}^{\mathbf{0}}$, inciso I, da Lei $\mathbf{n}^{\circ} \mathbf{1 0 . 6 8 3}$, de 2003, dispondo sobre a atuação conjunta dos Ministérios da Pesca e Aquicultura e do Meio Ambiente nos aspectos relacionados ao uso sustentável dos 
recursos pesqueiros. Disponível em: < http://goo.gl/IHtMhV>. Acesso em: 21 Novembro 2013.

BRASIL. Instrução Normativa MPA Nº 6 DE 29/06/2012. Diário oficial [da] república federativa do Brasil, poder Executivo, Brasília, DF, 3 jul. 2012. Seção 1. Disponível em: < https://goo.gl/0vWiOg>. Acesso em: 17 Novembro de 2015.

BRASIL. Lei $n^{\circ} 11.892$, de 29 de dezembro de 2008. Institui a Rede Federal de Educação Profissional, Científica e Tecnológica, cria os Institutos Federais de Educação, Ciência e Tecnologia, e dá outras providências. Disponível em: <http://goo.gl/BbAJAl>. Acesso em: 21 nov. 2013.

BRASIL. Lei $\mathrm{n}^{\mathrm{o}} 11.959$, de 29 de junho de 2009. Dispõe sobre a Política Nacional de Desenvolvimento Sustentável da Aquicultura e da Pesca, regula as atividades pesqueiras, revoga a Lei no 7.679, de 23 de novembro de 1988, e dispositivos do Decreto-Lei $\mathbf{n}^{\circ} 221$, de 28 de fevereiro de 1967, e dá outras providências. Disponível em: <http://www.planalto.gov.br/ccivil_03/_ato2007-2010/2009/Lei/L11959.htm>. Acesso em: 22 nov. 2014.

BRASIL. LEI N ${ }^{\circ}$ 5.764, DE 16 DE DEZEMBRO DE 1971. Define a Política Nacional de Cooperativismo, institui o regime jurídico das sociedades cooperativas, e dá outras providências. Disponível em: < http://goo.gl/aVjJPA>. Acesso em: 12 nov. 2015.

BRASIL. LEI No 9.394, DE 20 DE DEZEMBRO DE 1996. Estabelece as diretrizes e bases da educação nacional. Disponível em: < http://goo.gl/QvaB1M>. Acesso em: 13 Agosto de 2015.

BRASIL. LEI $\mathrm{N}^{\mathrm{o}} 10.683$, DE 28 DE MAIO DE 2003. Dispõe sobre a organização da Presidência da República e dos Ministérios, e dá outras providências. Disponível em: < http://goo.gl/vXDz0l>. Acesso em: 14 Março de 2014.

CAJUCOCO. Sobre nós. Disponível em: < http://goo.gl/xiLcuj> Acesso em 28 de março de 2015.

CALLOU, Ângelo Brás Fernandes. Povos do mar: herança sociocultural e perspectivas no Brasil. Ciência e Cultura, São Paulo, v. 62, n. 3, p. 45-48, 2010. Disponível em: < http://goo.gl/UxOAjt >. Acesso em: 03 fev. 2015.

CÂMARA DOS DEPUTADOS. Decreto ${ }^{\circ}$ 7.566, de 23 de setembro de 1909. Crêa nas capitais dos Estados da Republica Escolas de Aprendizes Artífices, para o ensino profissional primário e gratuito. Disponível em: <http://goo.gl/nwMRwC $>$. Acesso em: 21 jan. 2015.

CASTRO, Luiz Humberto de. Arranjo produtivo local. Brasília, DF : SEBRAE, 2009. (Série Empreendimentos Coletivos)

COTRIM, Décio Souza. Agroecologia, sustentabilidade e os pescadores artesanais: o caso de Tramandaí (RS). 2008. Dissertação (Mestrado em Desenvolvimento Rural) - Faculdade de Ciências Econômicas, Universidade Federal do Rio Grande do Sul, Rio Grande do Sul, 2008.

CRESWELL, John W. Projeto de Pesquisa: métodos qualitativo, quantitativo e misto. 3. ed. Porto Alegre: Artmed, 2010. 
DAL-FARRA, Rossano André; LOPES, Paulo Tadeu Campos. Métodos mistos de pesquisa em Educação: pressupostos teóricos. Nuances: estudos sobre Educação, Presidente Prudente, v. 24, n. 3, p. 67-80, set./dez. 2013. Disponível em: < http://goo.gl/13wIqL >. Acesso em: 03 fev. 2015 .

DIEGUES, A. C. S. Pescadores, camponeses e trabalhadores do mar. São Paulo: Ática, 1983.

FALCKE, Denise; WAGNER, Adriana. A dinâmica familiar e o fenômeno da transgeracionalidade: definição de conceitos. In: WAGNER, Adriana (org). Como se perpetua a família? A transmissão dos modelos familiares. Porto Alegre: EDIPUCRS, 2005.

FREY, K. Políticas públicas: um debate conceitual e reflexões referentes à prática da análise de políticas públicas no Brasil. Planejamento e Políticas Públicas, n. 21, p. 211-259, jun. 2000.

GARCIA, Narjara Mendes. Educação nas famílias de pescadores artesanais: transmissão geracional e processos de resiliência. 2007. 86 f. Dissertação (Mestrado em Educação Ambiental) - Programa de Pós-Graduação em Educação Ambiental. Fundação Universidade Federal do Rio Grande, Rio Grande, RS, 2007. Disponível em: < http://goo.gl/bH63ID >. Acesso em: 03 fevereiro de 2015.

GONÇALVES, Alex Augusto. Tecnologia do pescado: ciência, tecnologia, inovação e legislação. São Paulo: Atheneu, 2011.

GOVERNO MUNICIPAL DE ACARAÚ. Disponível em

<http://www.acarau.ce.gov.br/acarau.html>. Acesso em 09 fevereiro de 2015.

HOFLING, E. M. Estado e políticas (públicas) sociais. Cadernos Cedes, Campinas, v. 1, n. 55, nov. 2001.

HOMERO. A Odisséia. Rio de Janeiro, Ediouro, 1985.

IBGE: Ceará: Acaraú. Disponível em: <http://cod.ibge.gov.br/A7A > acesso em: 06 de Novembro de 2015.

INSTITUTO DE PESQUISA E ESTRATÉGIA ECONÔMICA DO CEARÁ. Perfil básico municipal: 2012: Acaraú. Fortaleza: IPECE, 2012. Disponível em: 〈http://goo.gl/v9HKTG〉 acesso em: 10 de Novembro de 2015.

INSTITUTO FEDERAL DE EDUCAÇÃO, CIÊNCIA E TECNOLOGIA DO CEARÁ. Plano de Desenvolvimento Institucional dos Campi (2009-2013). Fortaleza: IFCE, 2009. Disponível em: <http://www.ifce.edu.br/images/arquivos/doc_institucionais/pdi/pdi_2009-2013.pdf>. Acesso em: 03 fev. 2015.

LOPES, Vera de Fátima Maciel; et al. Dinâmicas territoriais e a organização dos pescadores: A experiência da rede solidária da pesca no Brasil. Revista da Gestão Costeira Integrada, v. 11, n. 2, p. 187-96, 2011. Disponível em: 〈http://www.aprh.pt/rgci/pdf/rgci-230_Lopes.pdf〉. Acesso em: 03 fev. 2015.

MALDONADO, Simone Carneiro. Mestres \& Mares. São Paulo: Ánnalube, 1993. 
Pescadores do mar. São Paulo: Ática, 1986. (Séries Princípios)

MELO, Vinícios Pagani de. Políticas públicas e a sustentabilidade da pesca marinha no Brasil. 2012. Dissertação (Mestrado em Economia) - Universidade Estadual Paulista, Faculdade de Ciências e Letras, Campus de Araraquara.

MINISTÉRIO DA PESCA E AQUICULTURA. Brasil. Pesca. Disponível em: <http://www.mpa.gov.br/index.php/pesca>. Acesso em: 22 nov. 2014.

Brasil. Boletim do registro geral da atividade pesqueira: RGP: 2012. Brasília, DF: MPA, 2012. Disponível em: < http://goo.gl/Ky26zB> Acesso em 12 de outubro de 2015.

MONTEIRO PESCADO. A empresa. Disponível em: < http://goo.gl/kzH3bs> Acesso em 28 de Março de 2015.

MUNIZ, Túlio de Souza. O ouro do mar: do surgimento da indústria da pesca da lagosta no Brasil à condição do pescador artesanal na história do tempo presente (1955-2000): Uma narrativa sócio-histórico marítima. 2005. 132 f. Dissertação (Mestrado em História Social) Programa de Pós-Graduação em História, Centro de Humanidades, Universidade Federal do Ceará, Fortaleza, 2005. Disponível em: <http://www.historia.ufc.br/admin/upload/DISSERTA\%C3\%87AOTULIO.pdf>. Acesso em: 03 fev. 2015.

OLIVEIRA, Maria Marly de. Como fazer pesquisa qualitativa. 5. ed. Petrópolis, RJ: Vozes, 2013.

ORGANIZAÇÃO DA COOPERATIVAS BRASILEIRAS. Agenda institucional do cooperativismo. Brasília, DF: OCB, 2015. Disponível em: <http://goo.gl/jPvQ44> Acesso em: $29 / 11 / 2015$

PAIVA, Melquíades Pinto. Nordeste do Brasil: terra, mar e gente. São Paulo: Õte, 2010.

PIERRI, Naína; AZEVEDO, Natália Tavares de. A Política Pesqueira atual no Brasil: a escolha pelo crescimento produtivo em detrimento da pesca artesanal. Samudra Report, n. 64, p. 34-41, 2013.

RIOS, Antoniel de oliveira; REGO, Rita de Cássia Franco; PENA, Paulo Gilvane Lopes. Doenças em trabalhadores da pesca. Revista brasileira de saúde pública, v. 35 , n. 1, p. 175188, jan./mar. 2011.

SARAIVA, Soniamar Zschornack Rodrigues. Caracterização socioeconômica da pesca artesanal na Ilha dos Coqueiros em Acaraú: Estado do Ceará, 2015. Dissertação (mestrado) Universidade Federal do Ceará, Instituto de Ciências do Mar, Programa de Pós-Graduação em Ciências Marinhas Tropicais, Fortaleza, 2015.

SEBRAE/SC. Santa Catarina em Números: pesca e aquicultura. Florianópolis: Sebrae/SC, 2010.

SILVA, Fausta Calado. et al. Educação para inclusão: programa pescando letras, Florianópolis. In: FAZENDO GÊNERO, 8, 2008, Florianópolis. 
SOBRINHO, Pompeu. Algumas notas sobre a hidrografia cearense: evolução cultural e perspectivas. Aspectos, Fortaleza, v.1, p. 57-94, 1967

SOUZA, C. Políticas públicas: uma revisão da literatura. Sociologias, Porto Alegre, v. 8, n. 16, p. 20-45, jul./dez. 2006.

SPARTA, Mônica; GOMES, William B. Importância atribuída ao ingresso na educação superior por alunos do ensino médio. Revista Brasileira de Orientação Profissional, Porto Alegre, v. 6, n.2, p. 45-53, 2005

SUSANE, Deborah. Presidente Lula inaugura três campi do IFCE. In: Instituto Federal do Ceará - IFCE. Disponível em: < http://goo.gl/AvLiLJ>. Acesso em: 03 Fevereiro de 2015.

VIEIRA, Paulo Freire; FILARDI, Ana Carla; REBOUÇAS, Gabriel Nunes. Gestão integrada e participativa da pesca artesanal: potencialidades e obstáculos no litoral de Santa Catarina. Ambiente \& Sociedade. v. 9, n. 2, jul./dez.2006. 
APÊNDICE A - Carta solicitando autorização para realização da pesquisa junto às

Escolas Estaduais de Ensino Médio à CREDE - Coordenadoria Regional de Educação

\section{Prezada Coordenadora,}

Sou servidora do IFCE, campus Acaraú, e aluna do Programa de Pós Graduação da Faculdade de Educação da Universidade de Brasília - UnB, na área de concentração "Políticas Públicas e Gestão da Educação Profissional e Tecnológica" do Mestrado Profissional.

Estou realizando uma pesquisa sob a orientação do Prof. Dr. Bernardo Kipnis, cujo objetivo é estudar a oferta e a demanda do Curso Técnico de Nível Médio Subsequente em Pesca, do Instituto Federal de Educação, Ciência e Tecnologia - IFCE.

Gostaria de contar com a colaboração desta Coordenadoria no sentido de autorizar e conceder acesso a esta pesquisadora junto às escolas de ensino médio de Acaraú e Distritos, para realizar a aplicação de questionário aos alunos do 3 o ano do ensino médio (questionário anexo).

Informo que a participação dos alunos é voluntária, que a identidade dos mesmos e as informações por eles prestadas são sigilosas.

A opinião dos estudantes sobre o tema contribuirá bastante para a compreensão do assunto a ser estudado, razão pela qual, desde já, agradeço a sua disposição em me receber e sua valiosa contribuição para a produção e desenvolvimento do conhecimento científico.

Quaisquer dúvidas relativas à pesquisa poderão ser esclarecidas pela pesquisadora, Juliane Vargas, fone: (88) 9740-9302 ou pela Coordenadora do Programa de Pós-Graduação em Educação - FE/UnB, do Mestrado Profissional, Prof. Dra. Olgamir Francisco de Carvalho, Fone: (61) 3107-6194.

Atenciosamente,

Acaraú, 05 de maio de 2015.

\section{Juliane Vargas}


APÊNDICE B - Termo de Consentimento Questionário Semiestruturado

\section{TERMO DE CONSENTIMENTO LIVRE E ESCLARECIDO}

Prezado(a) participante:

Sou aluna do Programa de Pós Graduação da Faculdade de Educação da Universidade de Brasília - UnB, na área de concentração "Políticas Públicas e Gestão da Educação Profissional e Tecnológica” do Mestrado Profissional.

Estou realizando uma pesquisa sob a orientação do Prof. Dr. Bernardo Kipnis, cujo objetivo é estudar a oferta e a demanda do Curso Técnico de Nível Médio Subsequente em Pesca, do Instituto Federal de Educação, Ciência e Tecnologia - IFCE.

Desta forma, gostaria de convidá-lo(a) a colaborar de forma voluntária com esta pesquisa. Para isso, foi criado um questionário com perguntas específicas sobre o assunto a ser estudado. Se decidir não participar ou quiser desistir de continuar em qualquer momento, tem absoluta liberdade de fazê-lo.

Os resultados desta pesquisa serão publicados, mas sua privacidade será respeitada, pois sua identidade e as informações prestadas serão mantidas em sigilo.

Mesmo não tendo benefícios diretos ou qualquer vantagem financeira ao participar da pesquisa, indiretamente você estará contribuindo para a compreensão do assunto estudado e para a produção de conhecimento científico.

Tenho interesse em entrevistar os seus pais ou representantes legais a respeito da atividade de Pesca, por isso se você autorizar que eu os procure futuramente favor assinalar com um " $X$ " em um dos campos abaixo.

Quaisquer dúvidas relativas à pesquisa poderão ser esclarecidas pela pesquisadora, Juliane Vargas, fone: (88) 9740-9302 ou pela Coordenadora do Programa de Pós-Graduação em Educação - FE/UnB, do Mestrado Profissional, Prof. Dra. Olgamir Francisco de Carvalho, Fone: (61) 3107-6194.

Página 1 de 
Favor marcar "X" em apenas um dos parênteses.

( ) Concordo em participar voluntariamente do estudo

( ) Concordo em participar voluntariamente do estudo e com a entrevista de meus pais ou representantes

Atenciosamente,

Acaraú, de 2015.

Juliane Vargas - Matrícula 130178730

Assinatura do Participante

Assinatura do Representante Legal

Dados do Participante:

Nome completo:

Endereço:

Telefones:

E-mail:

Orientador:

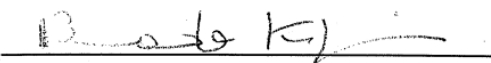

Prof. Dr. Bernardo Kipnis

Página 2 de 2 
APÊNDICE C - Termo de Consentimento Entrevista

TERMO DE CONSENTIMENTO LIVRE E ESCLARECIDO

Prezado(a) participante:

Sou aluna do Programa de Pós Graduação da Faculdade de Educação da Universidade de Brasília - UnB, na área de concentração "Políticas Públicas e Gestão da Educação Profissional e Tecnológica” do Mestrado Profissional.

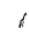

Estou realizando uma pesquisa sob a orientação do Prof. Dr. Bernardo Kipnis, cujo objetivo é estudar a oferta e a demanda do Curso Técnico de Nível Médio Subsequente em Pesca, do Instituto Federal de Educação, Ciência e Tecnologia - IFCE.

Desta forma, gostaria de convidá-lo(a) a colaborar de forma voluntária com esta pesquisa. Para isso, foi criado um roteiro de entrevistas com perguntas específicas sobre o assunto a ser estudado. Se decidir não participar ou quiser desistir de continuar em qualquer momento, tem absoluta liberdade de fazê-lo.

Os resultados desta pesquisa serão publicados, mas sua privacidade será respeitada, pois sua identidade e as informações prestadas serão mantidas em sigilo.

Mesmo não tendo benefícios diretos ou qualquer vantagem financeira ao participar da pesquisa, indiretamente você estará contribuindo para a compreensão do assunto estudado e para a produção de conhecimento científico.

Quaisquer dúvidas relativas à pesquisa poderão ser esclarecidas pela pesquisadora, Juliane Vargas, fone: (88) 9740-9302 ou pela Coordenadora do Programa de Pós-Graduação em Educação - FE/UnB, do Mestrado Profissional, Prof. Dra. Olgamir Francisco de Carvalho, Fone: (61) 3107-6194.

( ) Concordo em participar voluntariamente do estudo e com a gravação da entrevista. 
Atenciosamente,

Acaraú, de 2015

Juliane Vargas - Matrícula 130178730

Assinatura do Participante

Dados do Participante:

Nome completo:

Endereço:

Telefones:

E-mail:

Orientador:

$\frac{\sqrt{3}-0 \text { de }}{\text { Prof. Dr. Bernardo Kipnis }}$

Página 2 de 2 
APÊEDICE D - Instrumentos de Pesquisa (questionário e roteiros de entrevista)

\author{
Universidade de Brasília - UnB \\ Programa de Pós Graduação da Faculdade de Educação \\ Políticas Públicas e Gestão da Educação Profissional e Tecnológica \\ Mestrado Profissional
}

Questionário - Alunos / Data de aplicação:

\begin{tabular}{|l|l|}
\hline Escola: & Local: \\
\hline Período: & Turma: \\
\hline Aluno(a): & Sexo: ( )F ( ) M \\
\hline Endereço: & Fone: \\
\hline E-mail: & \multicolumn{2}{|l|}{} \\
\hline
\end{tabular}

1. Depois de concluir o ensino médio, você pretende continuar os seus estudos?

( ) Sim ( ) Não ( ) Não sei

2. Se você tivesse a oportunidade de escolher qualquer curso para seguir uma profissão, qual escolheria?

Resposta:

3. Após concluir o ensino médio e se continuasse os estudos, qual seria a sua opção:

( ) Técnico Subsequente ( ) Tecnólogo ( ) Bacharelado ( )

Licenciatura

Justifique a resposta:

4. Você conhece o IFCE - Instituto Federal de Educação Ciência e Tecnologia do Ceará?

( ) $\operatorname{Sim}($ ) Não

5. Atualmente o IFCE oferta 4 Cursos Técnicos Subsequentes de Nível Médio, para aqueles que já concluíram o ensino médio. Se você tivesse que escolher entre os 4 , qual você escolheria, em ordem de preferência? (Iniciando com 1 para a maior preferência)

( ) Aquicultura ( ) Construção Naval ( ) Pesca ( ) Restaurante e Bar

( ) Nenhum

6. Você conhece o Curso Técnico em Pesca do IFCE?

( ) Sim, com profundidade ( ) Sim, razoavelmente ( ) Não, mas já ouvi falar ( ) Não, nunca ouvi falar

7. Como chegou a conhecê-lo? Responda apenas se assinalou "sim" na questão anterior.

( ) Rádio ( ) Internet ( ) amigos ou parentes que estudam no IFCE

( ) Cartazes pela cidade ( ) visita de sua escola ao câmpus do IFCE ( ) visita do

IFCE na sua escola ( ) outro meio

Se respondeu "outro meio", informe qual: 
8. Se você decidisse ingressar no Curso Técnico em Pesca do IFCE, seus pais incentivariam?

( ) Sim ( ) Não ( ) Seriam indiferentes ( ) Não sei responder

9. Alguém de sua família é pescador ou pescadora?

( ) Avôs e/ou Avós ( ) Pai e/ou Mãe ( ) Tios e/ou Tias ( ) Irmãos e/ou Irmãs

( ) Primos e/ou Primas ( ) Parentes mais distantes ( ) Ninguém 
Universidade de Brasília - UnB

Programa de Pós Graduação da Faculdade de Educação

Políticas Públicas e Gestão da Educação Profissional e Tecnológica

Mestrado Profissional

Roteiro de Entrevista - Genitores ou Responsáveis Legais dos alunos

\begin{tabular}{|c|c|c|c|}
\hline Nome: & & & Relação de Parentesco: \\
\hline Data: & Início: & Término: & Local: \\
\hline
\end{tabular}

Orientações gerais iniciais: agradecer a participação do entrevistado; informar o motivo da visita e a importância de sua participação; comunicar que o depoimento é confidencial; explicar o conteúdo do TCLE e colher assinatura; informar a duração máxima esperada da entrevista (1h); pedir autorização para gravar.

Orientações para depois da entrevista: perguntar se pode entrar em contato novamente para esclarecer alguma questão ou dúvida; agradecer novamente a participação.

1. Sexo:

( ) Feminino ( ) Masculino

\section{Escolaridade:}

) não alfabetizado

) fundamental incompleto

) fundamental completo

) ensino médio incompleto

) ensino médio completo

) superior incompleto

) superior completo

\section{Qual a sua atividade profissional?}

\section{Remuneração atual:}

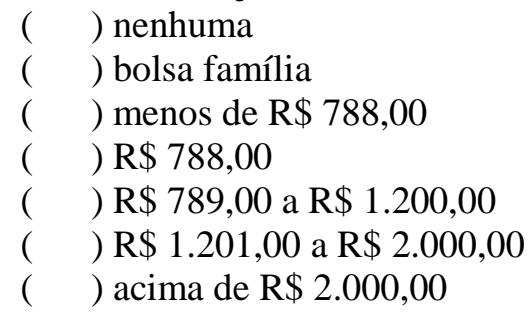

5. O sr(a) acha que a profissão de pescador é valorizada pela sociedade?

6. Se o seu filho(a) decidisse ingressar no Curso Técnico em Pesca do IFCE, o sr(a) incentivaria?

7. O sr(a) acha que a Pesca pode assegurar um bom futuro para o seu filho(a)?

8. Se você pudesse escolher uma profissão para o seu filho(a), qual escolheria?

8.a. Você incentivaria seu filho a ir para a Universidade? 
*** Continuar as perguntas abaixo com pescadores/marisqueiras

9. Fale um pouco sobre a sua atividade de pescador.

10. O sr(a) é Pescador Artesanal ou Pescador Industrial?

11. O sr(a) trabalha de carteira de trabalho assinada?

12. Na atividade pesqueira, quem lucra mais com produto da pesca?

13. Quais são as maiores dificuldades ou pontos negativos da sua profissão? 


$$
\begin{gathered}
\text { Universidade de Brasília - UnB } \\
\text { Programa de Pós Graduação da Faculdade de Educação } \\
\text { Políticas Públicas e Gestão da Educação Profissional e Tecnológica } \\
\text { Mestrado Profissional }
\end{gathered}
$$

\begin{tabular}{|c|c|}
\hline Nome: & \\
\hline Data: & Início: \\
\hline
\end{tabular}

\section{Roteiro de Entrevista - Servidores do IFCE}

Orientações gerais iniciais: agradecer a participação do entrevistado; informar o motivo da visita e a importância de sua participação; comunicar que o depoimento é confidencial; explicar o conteúdo do TCLE e colher assinatura; informar a duração máxima esperada da entrevista (1h); pedir autorização para gravar.

Orientações para depois da entrevista: perguntar se pode entrar em contato novamente para esclarecer alguma questão ou dúvida; agradecer novamente a participação.

1. Você acompanhou o processo de implantação do curso?

As questões de $n^{\circ} 2$ a 6 somente para aqueles que afirmaram "sim".

2. O que levou o IFCE a oferecer o Curso Técnico Subsequente em Pesca e quais os critérios que subsidiaram essa decisão?

3. Houve consulta sobre a criação do curso aos diversos setores da sociedade? Se sim, como foi esse processo?

4. Como resultado dessa consulta foram firmados compromissos com o IFCE? Pode citar alguns?

5. A comunidade opinou sobre curso em audiência pública?

6. Poderia citar quais foram as maiores facilidades e dificuldades encontradas durante o processo de implantação?

7. Dados fornecidos pela CCA indicam baixa demanda em relação ao Curso Técnico em Pesca e que este está em último lugar no ranking de preferência dos candidatos aos cursos técnicos. Qual sua opinião sobre essa questão?

8. A forma como o Curso Técnico em Pesca foi estruturado atende a uma formação mais técnica e prática ou segue uma perspectiva mais acadêmica?

9. Quais são as demandas do setor pesqueiro local e da região que podem ser atendidas por um técnico de nível médio em pesca?

10. O IFCE já realizou ou realiza serviços de suporte à atividade pesqueira, como cursos de extensão? Você se lembra de alguns?

11. Em termos de estrutura física (salas e seus componentes, biblioteca, laboratórios e equipamentos) e corpo docente (titulação, experiência no mercado de trabalho, capacitação pedagógica), relacione os aspectos positivos e negativos do curso.

12. Como é feita a divulgação dos cursos técnicos ofertados pelo IFCE, em especial o de Pesca? 
Universidade de Brasília - UnB

Programa de Pós Graduação da Faculdade de Educação

Políticas Públicas e Gestão da Educação Profissional e Tecnológica

Mestrado Profissional

Roteiro de Entrevista - Servidor do MEC/SETEC

\begin{tabular}{|l|l|l|l|}
\hline \multicolumn{2}{|l|}{ Nome: } & Cargo/Função: \\
\hline Data: & Início: & Término: & Local: \\
\hline
\end{tabular}

Orientações gerais iniciais: agradecer a participação do entrevistado; informar o motivo da visita e a importância de sua participação; comunicar que o depoimento é confidencial; explicar o conteúdo do TCLE e colher assinatura; informar a duração máxima esperada da entrevista (1h); pedir autorização para gravar.

Orientações para depois da entrevista: perguntar se pode entrar em contato novamente para esclarecer alguma questão ou dúvida; agradecer novamente a participação.

1. Professor, o senhor esteve à frente da Coordenação Nacional da Política de Formação Humana na Área de Pesca Marinha e Continental e Aquicultura Familiar, Portos e Navegação da Secretaria de Educação Profissional e Tecnológica do Ministério da Educação, em que período?

2. Quais foram e quando se iniciaram as primeiras intenções governamentais no que se refere ao planejamento e estruturação de uma política voltada à área da Pesca?

3. Na sua opinião, quais foram as principais políticas públicas do MEC/SETEC voltadas à Política de Formação Humana na área da pesca?

4. Quais são os principais eixos da Política de Formação Humana na área da pesca?

5. Qual é o público alvo afetado por essas políticas?

6. Qual é o papel dos institutos federais e dos núcleos de pesquisa aplicados à Pesca e Aquicultura - os chamados NUPAS - nesse contexto? 